\title{
Regulation of Ascorbate-Glutathione Pathway in Mitigating Oxidative Damage in Plants under Abiotic Stress
}

\author{
Mirza Hasanuzzaman ${ }^{1, *}$, M. H. M. Borhannuddin Bhuyan ${ }^{2,3}{ }^{\circledR}$, Taufika Islam Anee ${ }^{1}(\mathbb{D}$, \\ Khursheda Parvin ${ }^{2,4}$, Kamrun Nahar ${ }^{5}$, Jubayer Al Mahmud ${ }^{6}$ and Masayuki Fujita ${ }^{2, *}$ \\ 1 Department of Agronomy, Faculty of Agriculture, Sher-e-Bangla Agricultural University, \\ Dhaka 1207, Bangladesh \\ 2 Laboratory of Plant Stress Responses, Department of Applied Biological Science, Faculty of Agriculture, \\ Kagawa University, Miki-cho, Kita-gun, Kagawa 761-0795, Japan \\ 3 Citrus Research Station, Bangladesh Agricultural Research Institute, Jaintapur, Sylhet 3156, Bangladesh \\ 4 Department of Horticulture, Faculty of Agriculture, Sher-e-Bangla Agricultural University, \\ Dhaka 1207, Bangladesh \\ 5 Department of Agricultural Botany, Faculty of Agriculture, Sher-e-Bangla Agricultural University, \\ Dhaka 1207, Bangladesh \\ 6 Department of Agroforestry and Environmental Science, Faculty of Agriculture, Sher-e-Bangla Agricultural \\ University, Dhaka 1207, Bangladesh \\ * Correspondence: mhzsauag@yahoo.com (M.H.); fujita@ag.kagawa-u.ac.jp (M.F.); \\ Tel.: +88-017-1659-7711 (M.H.); +81-878-913-033 (M.F.)
}

Received: 30 June 2019; Accepted: 5 September 2019; Published: 9 September 2019

\begin{abstract}
Reactive oxygen species (ROS) generation is a usual phenomenon in a plant both under a normal and stressed condition. However, under unfavorable or adverse conditions, ROS production exceeds the capacity of the antioxidant defense system. Both non-enzymatic and enzymatic components of the antioxidant defense system either detoxify or scavenge ROS and mitigate their deleterious effects. The Ascorbate-Glutathione (AsA-GSH) pathway, also known as Asada-Halliwell pathway comprises of AsA, GSH, and four enzymes viz. ascorbate peroxidase, monodehydroascorbate reductase, dehydroascorbate reductase, and glutathione reductase, play a vital role in detoxifying ROS. Apart from ROS detoxification, they also interact with other defense systems in plants and protect the plants from various abiotic stress-induced damages. Several plant studies revealed that the upregulation or overexpression of AsA-GSH pathway enzymes and the enhancement of the AsA and GSH levels conferred plants better tolerance to abiotic stresses by reducing the ROS. In this review, we summarize the recent progress of the research on AsA-GSH pathway in terms of oxidative stress tolerance in plants. We also focus on the defense mechanisms as well as molecular interactions.
\end{abstract}

Keywords: antioxidant defense; free radicals; glyoxalase system; hydrogen peroxide; plant abiotic stress; reactive oxygen species; redox biology; stress signaling

\section{Introduction}

With the advancement of lifestyle the natural resources are being exploited and the interruption of natural environment is increasing the extremity of various kinds of abiotic stress, including salt stress, drought stress, waterlogging, temperature extremes, including high and low, excess and low light intensity, radiation stress, ozone, metal and metalloid toxicity, and other organic or inorganic pollutants. Environmental extremity narrows ways to increase plant productivity. Ever-increasing population demands newly cultivable areas, including the adverse land areas, even the higher crop production in per unit area. 
Any abiotic stress impaired stomatal function, photosystem activity, Calvin cycle, or photosynthetic enzyme activities, as well as altered electron transport chain reactions. Moreover, unfavorable peroxisomal or cytosolic atmosphere led to overwhelm of electron absorption and generate ROS as a common outcome and subsequently causes oxidative damage [1,2]. If the challenges of plant scientists are increasing productivity against the abiotic stresses, their concentrations are moving to the depth for breaking the obstacles at the cellular or organelles levels, where abiotic stresses impose common types of barrier to hinder their function. Reactive oxygen species is an inescapable outcome of aerobic reactions, which are partly reduced or activated by the appearance of oxygen. Reactive oxygen species is a combined name that indicates different, highly active components. Superoxide $\left(\mathrm{O}_{2}^{-}\right)$, hydroxyl $\left(\mathrm{OH}^{\bullet}\right)$, and peroxyl $\left(\mathrm{ROO}^{\bullet}\right)$ are some examples of oxygen radicals. Hydrogen peroxide $\left(\mathrm{H}_{2} \mathrm{O}_{2}\right)$, singlet oxygen $\left({ }^{1} \mathrm{O}_{2}\right)$, and ozone $\left(\mathrm{O}_{3}\right)$ are the non-radical types of ROS [3]. Reactive oxygen species are important for plants. They have dual role in plants: a small amount of those acts as a signal for inducing abiotic stress responses towards adaptation process, while the excess generation of those causes oxidative damage. However, in severe cases, oxidative damages to membranes (lipid peroxidation), proteins, nucleic acid, including RNA and DNA, and even directs to the oxidative obliteration of the cell [4]. Chloroplast, mitochondrion, membranes of the cell or its ultrastructural organelles, apoplast, and nucleolus are the locations of ROS production. Nonetheless, peroxisome is also considered as a powerful source of ROS since the electron transport chain (ETC) and photochemical reactions are the majority of the processes generating ROS [5-7].

Plants have an antioxidant defense system having non-enzymatic and enzymatic antioxidants in cellular organelles, which scavenges different ROS up to a certain level. If the ROS generation is higher than the scavenging ability of the antioxidant system, then oxidative damage occurs. Antioxidant defense system comprises ascorbate (AsA), glutathione (GSH), carotenoids, tocopherols, flavonoids, etc., which are some commonly known non-enzymatic antioxidants [5]. Ascorbate peroxidase (APX), monodehydroascorbate reductase (MDHAR), dehydroascorbate reductase (DHAR), glutathione reductase (GR), superoxide dismutase (SOD), catalase (CAT), glutathione peroxidase (GPX), glutathione $S$-transferase (GST), and peroxiredoxin (PRX) are well known enzymatic antioxidant components [8,9]. Among all of these, AsA, GSH, APX, MDHAR, DHAR, and GR comprise the AsA-GSH cycle.

Ascorbate is one of the most powerful substrates for scavenging $\mathrm{H}_{2} \mathrm{O}_{2}$. Ascorbate maintains the reduced state of $\alpha$-tocopherol. Ascorbate is supposed to be concerned in zeaxanthin biosynthesis dissipating excess light energy in the thylakoid membranes of chloroplast and prevents oxidative stress. Ascorbate sustains reduce the state of prosthetic metal ions and maintain the activity of antioxidant enzymes [6]. Glutathione regulates various metabolic functions; it acts as an antioxidant. Glutathione peroxidase and GST utilize GSH as substrate; GPX is responsible for ROS detoxification, whereas GST is liable for xenobiotic detoxification [1]. The glyoxalase system consisting of glyoxalase I (Gly I) and glyoxalase II (Gly II) enzymes detoxifies cytotoxic and oxidative stress creator methylglyoxal (MG), where Gly I uses GSH and after finishing MG detoxification, GSH is recycled [2]. The positive role of AsA-GSH cycle components has been documented in many plants that are affected by abiotic stresses [1,2]. Participation of the GSH/glutathione disulfide (GSSG, the oxidized form of GSH) redox in maintaining a favorable cellular environment and in stress signal and adaptation were discussed in some previous findings. Glutathione participates in signal transduction, the proper pathway, of which remains unrevealed. The presence of AsA and GSH has been reported to improve osmoregulation, plant water status and nutrient status, water use efficiency, photosynthetic performance, and the overall productivity of plants. Exogenous AsA and GSH applications have been reported to enhance the antioxidant defense as well as the overall tolerance of plants against abiotic stresses. Accordingly, the enzymatic antioxidants of AsA-GSH cycle participates in scavenging ROS, whereas AsA and GSH not only directly scavenge a range of ROS but also perform many other functions to maintain a favorable state in cytosol and other cellular organelles to enhance antioxidant capacity and to reduce oxidative stress, which is induced by different abiotic stresses; AsA and GSH also improve the physiological performance of plants. Since the discovery of the AsA-GSH cycle, its most discussed 
topics are related to antioxidative protection. However, in this aspect, various other factors should be revealed like physiological factors/processes involved in generating oxidative stress, role of AsA-GSH cycle components in regulating those physiological processes and ultimately the oxidative stress. Considering the multiple vital roles of AsA-GSH cycle in mitigating oxidative stress, this review accommodates presently available and updates of research findings and perspectives.

\section{Ascorbate-Glutathione Pathway-An Overview}

Ascorbate-Glutathione pathway (also called as Asada-Halliwell pathway) is the major pathway of antioxidant defense, which mainly detoxify the $\mathrm{H}_{2} \mathrm{O}_{2}$ in a plant cell. Apart from AsA and GSH, its enzymes-APX, MDHAR, DHAR, and GR [6] - have significant roles. Both AsA and GSH are found in the cytosol, nucleus, chloroplast, mitochondria, and peroxisome, where they operate the functions assisted by four enzymes and, therefore, each enzyme has several isoforms that are based on the cellular localization [10]. Both AsA and GSH are present in cellular organelles in a millimolar range, for instance, in Arabidopsis thaliana, AsA concentration is the highest ( $22.8 \mathrm{mM})$ in the peroxisome, where GSH is highest $(14.9 \mathrm{mM})$ in mitochondria [11,12]. AsA and GSH both have high redox potentials and, therefore, interact with many components and pathways towards the maintenance of a generally reduced state. There are few steps, by which AsA and GSH work coordinately to detoxify $\mathrm{H}_{2} \mathrm{O}_{2}$, and at the same time, both AsA and GSH are regenerated. First, the enzyme APX converts $\mathrm{H}_{2} \mathrm{O}_{2}$ into the water with the help of AsA as an electron donor, which is also converted into monodehydroascorbate (MDHA). This MDHA again regenerates AsA by the activity of MDHAR and a part of this is spontaneously converted into dehydroascorbate (DHA). Later, DHA is reduced to AsA again by using GSH, which results in its oxidation to produce GSSG. Finally, this GSSG regenerates GSH by the activity of GR using NADPH as the electron donor (Figure 1). Both AsA and GSH are strong antioxidants, but the maintenance of their redox state is important in conferring stress tolerance in plants, which largely depends on the activities of the four enzymes that are associated with the AsA-GSH cycle [6,13]. In the next sections, we have described all of the components of the AsA-GSH pathway.

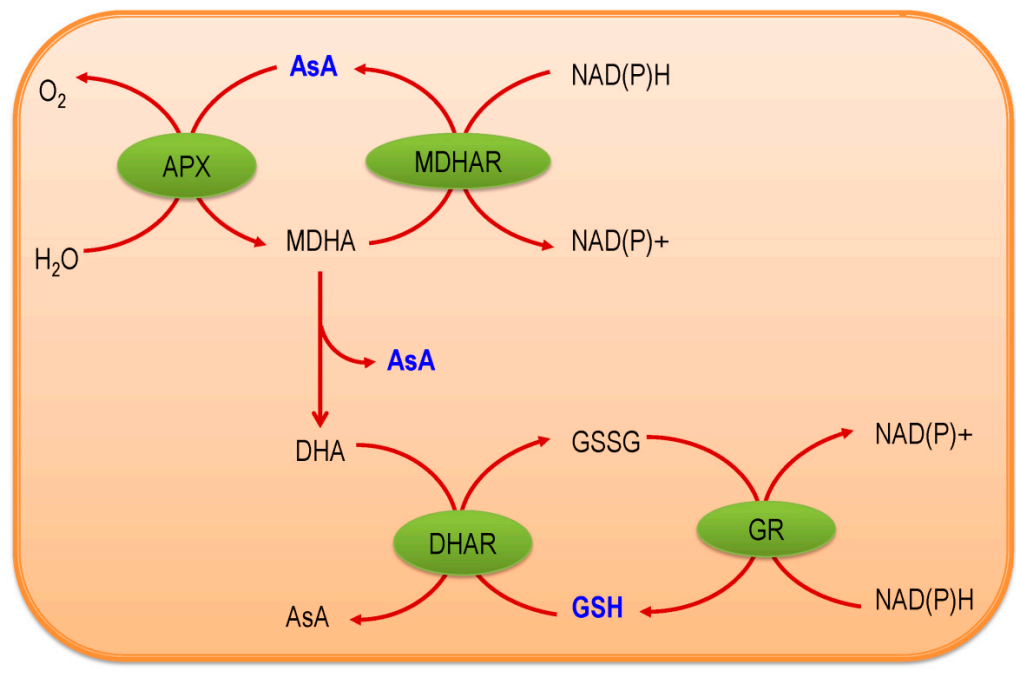

Figure 1. Ascorbate-Glutathione (AsA-GSH) (Ascorbate-Glutathione) pathway [ascorbate, AsA; ascorbate peroxidase, APX; monodehydroascorbate, MDHA; monodehydroascorbate reductase, MDHAR; dehydroascorbate, DHA; dehydroascorbate reductase, DHAR; glutathione, GSH; oxidized glutathione, GSSG; glutathione reductase, GR; Nicotinamide adenine dinucleotide phosphate (reduced form), NAD(P)H; Nicotinamide adenine dinucleotide phosphate (oxidized form), NAD $\left.(\mathrm{P})^{+}\right]$. 


\section{Components of AsA-GSH Pathway}

\subsection{Ascorbate}

All living organisms either make AsA (also known as Vitamin C) or get it in their foodstuffs. Naturally abundant L-AsA is of a simplest chemical structure and is related to C6 sugars. It is a hexonic acid aldono-1,4-lactone (either L-galacturonic or L-gulonic acid), having an enediol group at C2 and C3 [14]. The enediol group enables L-AsA for donating one or two electrons to form an initial oxidized intermediate (MDHA) and further to an oxidized (DHA) form. The C5 and C6-OH group serves to provide alcoholic nature. They can react with produced acetals, ketals by reacting with aldehydes and ketones, respectively. Having two asymmetric C, L-AsA illustratesa positive optical rotation, which is unaltered by the acidicpH of solution but greatly affected by alkaline $\mathrm{pH}$, which increases over $+160^{\circ}$ in $2 \mathrm{~N} \mathrm{NaOH}$ solution [14].

In solid-state, L-AsA is stable but oxidizes readily in solution, in particular in the presence of $\mathrm{Cu}$, $\mathrm{Fe}$, or alkali to form DHA. Afterward, two MDHA can undergo spontaneous reaction to rejuvenate one molecule of L-AsA and one molecule of DHA [15].

Ascorbate biosynthesis system is one of the ancient pathways and formed in very primitive life process on this planet. In plant tissue, AsA can be synthesized from several biochemical pathways. D-glucose is the primary substrate for producing AsA, and in this pathway, a set of ten reactions occurred (Figure 2). Ascorbate can be formed via four pathways viz. L-galactose, L-gulose, D-galacturonic acid, and myo-inositol pathway [16-18]. The biosynthesis of AsA is lineal with the cell wall formation. After the initial reactions, the D-galacturonic acid and L-galactose pathways both yielded L-galactono-1,4-lactone. Besides, in L-gulose and myo-inositol pathway, L-gulonic acid is produced, which is further hydrolyzes to form L-gulono-1,4-lactone, are catalyzed for the synthesizing of AsA in the mitochondria (Figure 2) [19].

In an organism, AsA metabolism comprises of biosynthesis (catabolism) and degradation (anabolism), and the balance between catabolism and anabolism determines the intracellular concentration of AsA. In the previous paragraph, we briefly discussed the biosynthesis of AsA. Hence, we will discuss the degradation and turnover of AsA in this paragraph. In some plants, the AsA turnover rate is relatively very high [20]. On the other hand, AsA is neither stable nor is restricted to oxido-reduction, which changes the equilibrium of AsA and DHA in plant tissue. The AsA pool undergoes turnover in plants. As AsA has prominent responsibility in the redox function metabolism, therefore the recycling of AsA from MDHA (catalyzed by MDHAR using NADPH) and DHA (DHAR using GSH) is the necessity to keep the redox balance as well as the higher total AsA pool [21]; and the functioning of the water-water cycle to optimize photosynthesis [22]. If the oxidized forms are not recovered, they will undergo further degradation to form oxalic or L-tartaric acids (Figure 2) [23]. In a plant cell, AsA act as a multifunctional biosynthetic precursor. While using radioactive ${ }^{14} \mathrm{C}$ AsA, some studies tried to understand the degradation of AsA and DHA, but the mechanism is still not fully understood (Figure 2) [24]. However, it is well understood that the cleavage between C2 and $\mathrm{C} 3$ results in oxalate formation, whereas the cleavage between $\mathrm{C} 3$ to $\mathrm{C} 6$ produces L-threonate, via L-idonate [25,26]. Furthermore, DHA can be hydrolyzed into 2,3-L-diketogulonate, being further oxidized to unknown intermediate (Figure 2) and catalyzed by ascorbate oxidase (AO). Sometimes, this intermediate produces toxic $\mathrm{H}_{2} \mathrm{O}_{2}$ non-enzymatically and it may inhibit peroxidase [24,27]. 


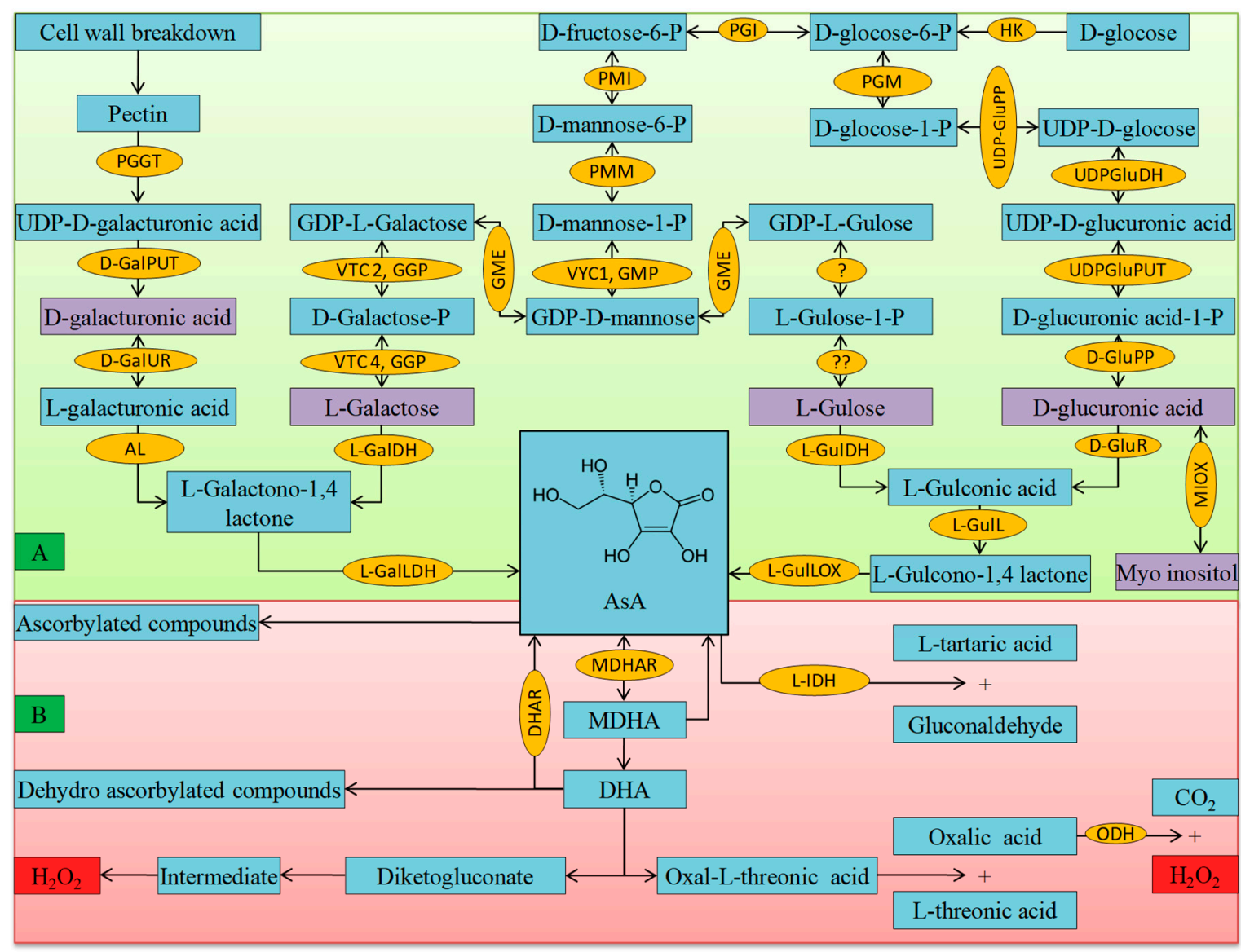

Figure 2. Ascorbate biosynthesis and metabolism is a complex set of reactions, some involving unidentified enzymes; some of the products are reactive and potentially damaging carbonyl compounds, (A) biosynthetic pathway; and, (B) regeneration and degradation pathways in plants. The metabolites in the violate box represent the name of each biosynthetic pathway. The elaborated name of enzymes are as follows (HK: Hexokinase; PGI: glucose-6-phosphate isomerase; PMI: mannose-6-phosphate isomeras; PMM: phosphomannomutase; TC1 or GMP: GDP-D-mannose pyrophosphorylase/mannose-1-phosphate guanylyltransferase; VTC2 or GGP: GDP-D-mannose 3',5'-epimerase, GME: GDP-L-galactose phosphorylase;VTC4 or GPP:L-galactose-1-phosphate phosphatase; GalDH: L-galactose dehydrogenase; L-GalLDH: L-galactono-1,4-lactone dehydrogenase; ?: nucleotide pyrophosphatase or sugar-1-phosphate guanyltransferase; ??: sugar phosphatase; L-GulDH: L-gulose dehydrogenase; L-GulL: L-gulonolactonase; L-GulLOX: L-gulono-1,4-lactone oxidase; PPGT: polygalacturonate 4-alpha-galacturonosyltransferase; D-GalPUT: D-galacturonate-1-phosphate uridyltransferase; D-GalUR: D-galacturonate reductase; AL: aldonolactonase; PGM: phosphoglucomutase; UDPGluPP: UDP-glucose-pyrophosphorylase; UDP-GluDH: UDP-glucose dehydrogenase; UDP-GluPUT: glucuronate-1-phosphate uridylyltransferase; D-GluPP: D-glucurono-1-phosphate phosphatase; MIOX: myo-inositol oxygenase; D-GluR: D-glucuronate reductase; MDHAR: monodehydroascorbate reductase; DHAR: dehydroascorbate reductase;L-IDH: L-Idodonate dehydrogenase).

\subsection{Glutathione}

Glutathione is an omnipresent low molecular weight tripeptide ( $\gamma$-L-glutamyl-L-cysteinylglycine; $\gamma$-Glu-Cys-Gly), which is a strong antioxidant and an essential metabolite with a multifarious role in plants [28,29]. It was first discovered from yeast cells subsequently in many plants and animal tissue. Later on, in 1936, it was found as the reducing agent present in the plant tissue [30].

Although GSH is composed of glutamine (Glu), cysteine (Cys), and glycine (Gly), three essential amino acids; but some plant may contain homologues of GSH, where Gly is replaced by other amino 
acids [31]. In plants, reduced GSH accounts for $>98 \%$ of total GSH [10]. Generally, cells possess three major reservoirs of GSH cytosol (80-85\%), mitochondria (10-15\%), and endoplasmic reticulum [32]. The thiol group is specific to $\gamma$-glutamyltranspeptidase (GGT) and it allows GSH a higher degree of stability [32,33]. Nevertheless, GSH plays a vital role, including antioxidant defense, xenobiotics detoxification, cell cycle regulation, and apoptosis, reserving cysteine, maintaining redox balance as well as immunity modulation and fibrogenesis [10,29].

In plants, GSH biosynthesis involves two enzymatic steps, which require ATP and the constituent amino acids (Figure 3). In the earliest stratum, $\gamma$-glutamylcysteine ( $\gamma$-EC) is produced by $\gamma$-glutamylcyteine synthetase ( $\gamma$-ECS, EC 6.3.2.2) catalysis and participation from Glu and Cys. In the next stratum, GSH is synthesized from $\gamma$-EC and Gly via bonding from the Cys residue of $\gamma$-EC with $\alpha$-amino group of Gly, catalyzed by GSH synthetase (GSH-S, EC 6.3.2.3, also known as GSH synthase). After synthesis in the cytoplasm, GSH is transported to other cellular organelles [34].

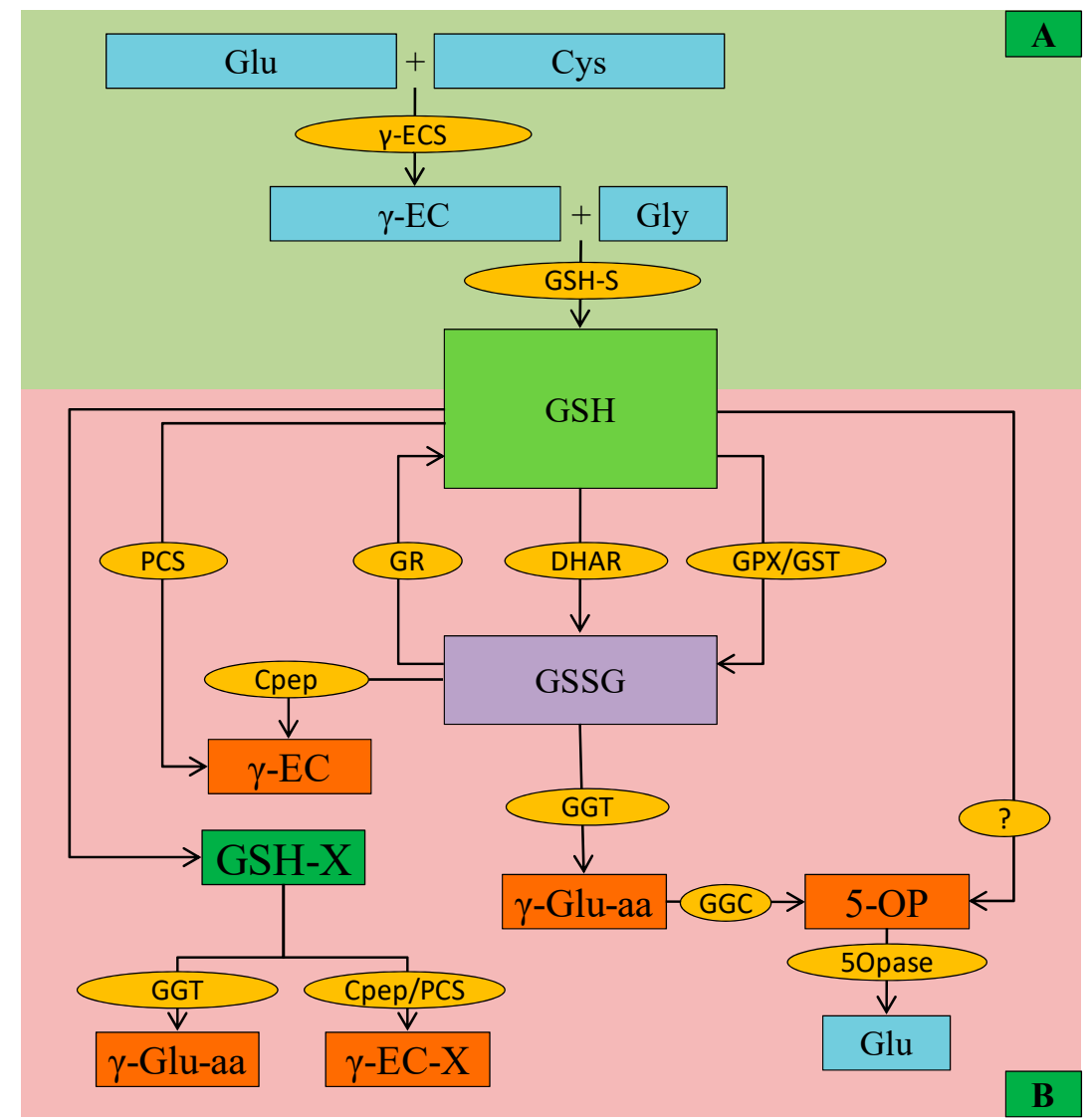

Figure 3. Glutathione biosynthesis, metabolism, and degradation in plants. (A) Biosynthesis the first step occurred in plastid: Glu and Cys form $\gamma$-glutamylcysteine $(\gamma$-EC) catalyzed by $\gamma$-EC synthetase ( $\gamma$-ECS). The second step occurred in the cytosol or in plastid: $\gamma$-EC and Gly bond together to form GSH catalyzed by GSH-S (glutathione synthase). Further, GSH participates in ROS scavenging and is converted into GSH/glutathione disulfide (GSSG) by the enzyme glutathione peroxidase (GPX), glutathione $S$-transferase (GST), and DHAR. Further GSSG can be recycled to GSH by the activity of glutathione reductase (GR). (B) In the degradation pathway, GSH and S-conjugated compound (GS-X) can be degraded to $\gamma$-EC and $\gamma$-EC-X by phytochelatin synthase (PCS). While, carboxypeptidase (Cpep) and $\gamma$-glutamyl transpeptidase (GGT) both could degrade GS-X to form $\gamma$-Glu-aa (aa, amino acid) and $\gamma$-EC-X, respectively. Similarly, GSSG is degraded by GGT and Cpep to form $\gamma$-Glu-aa and $\gamma$-EC, respectively. Further, the produced $\gamma$-Glu-aa is converted to 5-oxoproline (5-OP) by $\gamma$-glutamyl cyclotransferase (GGC). Besides, GSH is also converted to 5-OP. Although it is thought that this reaction is catalyzed by GGC, still it is unclear. 5-OP is converted to Glu in the next step by the action of 5-oxoprolinase (OPase). 
Glutathione is very important for various physiological processes, especially during abiotic stress; it coordinates with AsA turnover and is oxidized to GSSG [35]. Moreover, some other thiol-dependent enzymes, GPX and GST use GSH as co-factor, hence converted to GSSG, which is further reduced back to GSH, with GR catalysis. In higher plants, there are two genes that are reported to encode GRs (GR1 and GR2), where GR2 is essential for plant development [31,34].

The degradation of GSH is another important phenomenon of GSH metabolism (Figure 3). Up to now, as many as four types of GSH degrading enzymes have been described, which either use GSH or act on GSSG or other GSH-conjugates. Among them, carboxypeptidase activity could degrade GSH itself or GSH-conjugates. Cytosolic PCS is another enzyme that is responsible for the breakdown of GSH-conjugates that are mainly activated during metal/metalloid(s) stress. Another enzyme $\gamma$-glutamyl transpeptidase (GGT) acts in GSH transpeptidation or hydrolysis, which is further converted to free Glu by the action of GGC ( $\gamma$-glutamyl cyclotransferases) and 5-oxoprolinase (5-OPase) (Figure 3) [31,36]. Moreover, another vacuolar GGTs have been reported in Arabidopsis, which breaks GSH-conjugates [37]; hence, along with PCS, GGTs is important for metabolizing GSH-conjugates that is formed during secondary metabolites synthesis [37,38].

\subsection{Ascorbate Peroxidase}

The class I heme-peroxidases; APX (EC 1.11.1.11) occurred in several isoforms in plant cell, viz. cytosolic APX isoform (cAPX), mitochondrial APX isoform (mitAPX), peroxisomal and glyoxysomal APX isoform (mAPX), and chloroplastic APX isoform (chAPX) differed in their substrate specificity, molecular weight, optimal $\mathrm{pH}$ ranges between 7 and 8 for maximum activity and stability [39-41]. More importantly, isoforms activity is not stable when AsA is absent. For example, AsA concentrations those are lower than $20 \mu \mathrm{M}$ greatlyreduced chAPX activity. All of the APX isoforms are heme peroxidase they are inhibited by cyanide and azide. Iron plays a vital role in the APX catalytic site; hence, despite the presence of high AsA concentration, Fe deficiency reduced the activity of cAPX [42]. If the single Cys32 residue near arginine (Arg) 172 residue is altered, APX loses the ability to oxidize AsA to DHA, but it can oxidize other small aromatic molecules. Therefore, the APX properties differ with the guaiacol peroxidases, but they are 33\% identical with cytochrome c peroxidase (CCP) [43].

During $\mathrm{ROS}\left(\mathrm{H}_{2} \mathrm{O}_{2}\right)$ detoxification, APX binds $\mathrm{H}_{2} \mathrm{O}_{2}$ producing intermediate $(\mathrm{I})$, and heme iron $[\mathrm{Fe}(\mathrm{V})]$ is oxidized forming oxyferryl species $\left(\mathrm{Fe}^{4+}=\mathrm{O}\right)$. Afterward, APX is regenerated from $\mathrm{I}$, in a two-step reaction withAsA, where the AsA donate an electron and become oxidized. Detailed reactions are shown below (HS = Substrate, $\mathrm{S}=$ One electron oxidized form of the substrate).

$$
\begin{gathered}
\mathrm{APX}+\mathrm{H}_{2} \mathrm{O}_{2} \rightarrow \text { Intermediate }(\mathrm{I})+\mathrm{H}_{2} \mathrm{O} \\
\text { Intermediate } \mathrm{I}+\mathrm{HS} \rightarrow \text { Intermediate } \mathrm{II}+\mathrm{S} \\
\text { Intermediate } \mathrm{II}+\mathrm{HS} \rightarrow \mathrm{APX}+\mathrm{S}+\mathrm{H}_{2} \mathrm{O}
\end{gathered}
$$

In plant cell, APX scavenges $\mathrm{H}_{2} \mathrm{O}_{2}$, which mainly participates in AsA-GSH cycle catalyzes the reactions produces MDHA (Figure 4) and, subsequently, MDHA yields DHA [6,10,44]. 


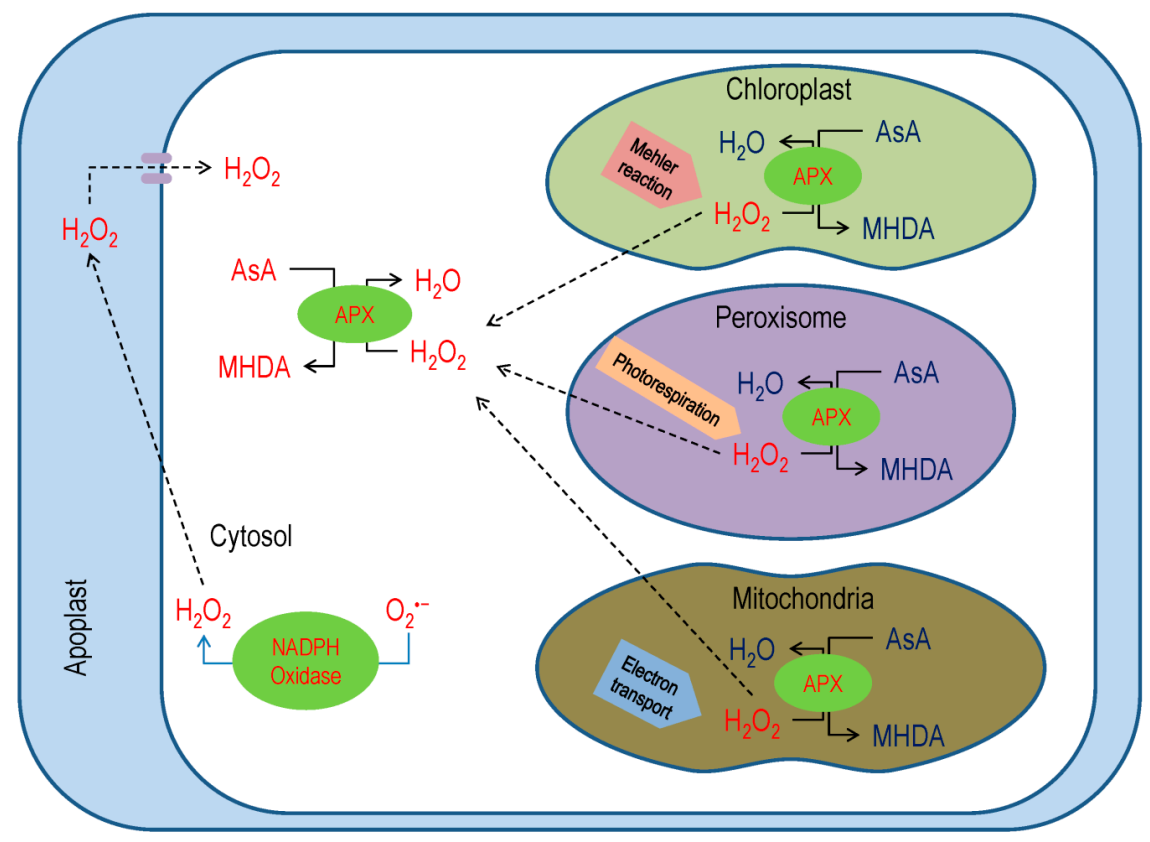

Figure 4. The function of Ascorbate peroxidase (APX) for the abolition of excess reactive oxygen species (ROS) generation in various cellular compartments. Additional details are in the text.

\subsection{Monodehydroascorbate Reductase}

The MDHAR (EC 1.6.5.4) helps in the revival of AsA [35], having several isoforms that are found in different organelles. Reports suggested that there are three MDHAR genes in tomato, five genes and six isoforms in Arabidopsis and rice, and as many as nineteen genes in wheat. In the plant cell, MDHAR activity was detected in different cell organelles, for instance, cytosol, mitochondria, chloroplasts, peroxisomes, and glyoxysomes (Figure 5) [45].

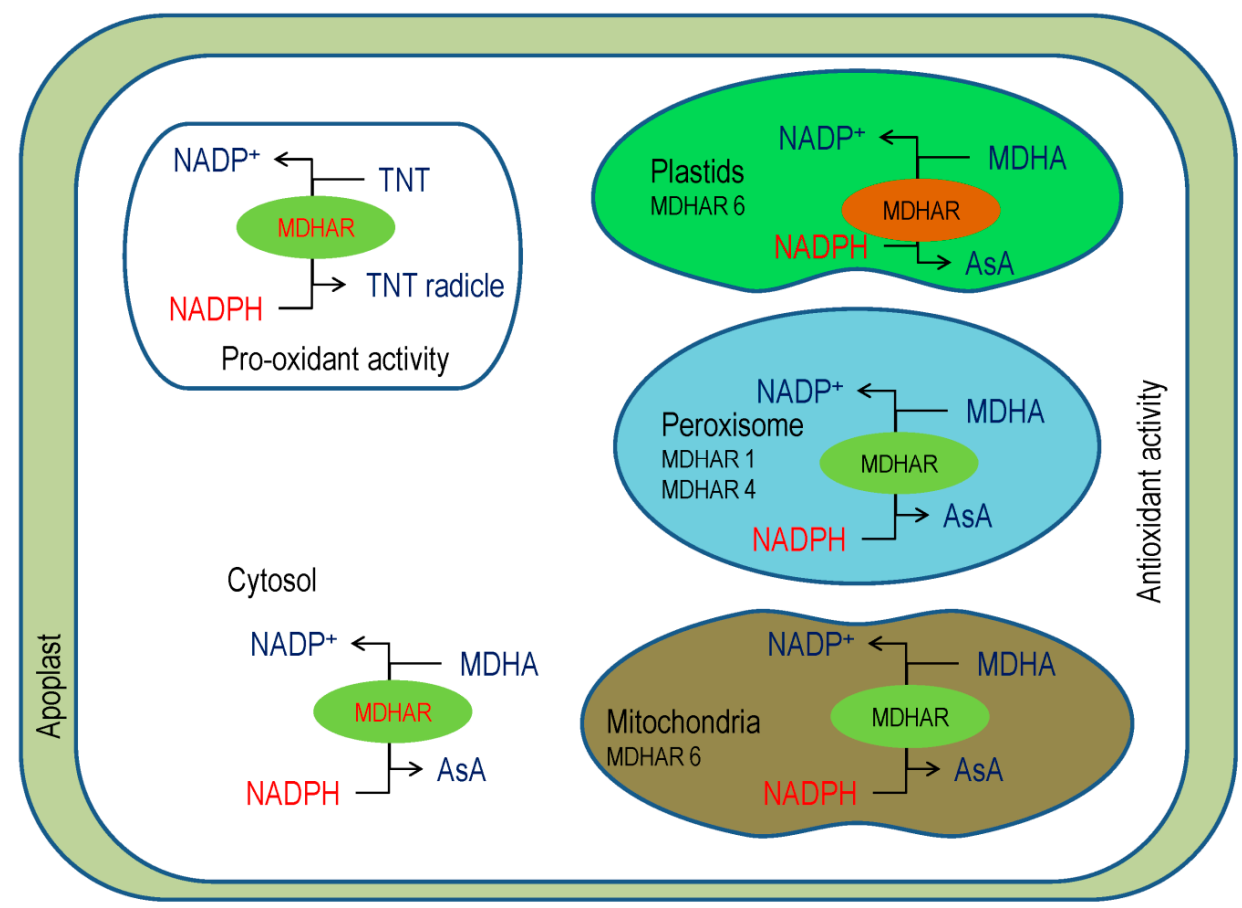

Figure 5. The antioxidant of MDHAR in regenerating AsA to support the removal of reactive oxygen species (ROS) (lower left) contrasts the pro-oxidant role of MDHAR creating 2,4,6-trinitrotoluene (TNT) toxicity. 
Although the enzyme is purified from several sources, the detailed structure of this enzyme was published in recent past. Begara-morales et al. [46] coined three-dimensional structure after conducting silico analysis of pea peroxisomal MDHAR. More recently, Park et al. [47] described details MDHAR composition from japonica rice. Those indicated that the structure of MDHAR consists of flavin adenine dinucleotide (FAD) and pyridine binding domain. The structure resembles Fe-S protein reductase [47]. The elucidated structure also indicates that rice MDHAR contains a typical $\alpha / \beta$ fold, and Arg320 and tyrosine (Tyr) 349 residues are vital for its activity. On the fad-binding domain, the fad is bounded by hydrogen and van der waals bond, where, Gly13, 15 and 297, alanine (Ala) 122 and 319, and threonine (Thr) 123 are involved and highly conservedin the bottom of the crevice. Moreover, Lys53 and Glu178 bridged together, which further bonded with proline (Pro) 49, where both Glu178 and Pro49, are highly conserved, as well as lysine (Lys) 53, Glu178, and FAD bonded each other. Among others, Arg48 compensate FAD phosphate group's negative charge.

In rice, MDHAR $\alpha$-helices surround $\beta$-sheets in the nicotinamide adenine dineucleotide (NAD)-binding domain, where the Tyr174, histidine (His) 315, and phenylalanine (Phe) 348 residues are shifted. Sandwiching between the FAD isoalloxazine ring and Tyr174, as well as steric hindrance moved Tyr174 away. The Phe348 residue shifts outward while His315 comes towards NAD binding site. In addition, the hydrogen bond is formed between Glu178 and nicotinamide ring; Arg202 and ribose and phosphate group, Glu314 and ribose; Glu196 and adenosine ring. Moreover, Glu196 offers rice MDHAR selectivity to NAD; preferring NADH over NADPH [47].

Interestingly, MDHAR can bind substrates other than MDHA, such as isoascorbic acid Evidence showed that phenoxyl radicals, like ferulic acid, quercetin, chlorogenic acid, and coniferyl alcohol, might be reduced by MDHAR [48]. In Arabidopsis, MDHAR activity reduces 2,4,6-trinitrotoluene (TNT) and creates its toxicity (Figure 5), but the MDHAR6 mutants are more tolerant, as TNT could not reduce and thus autooxidizes to creates $\mathrm{O}_{2}^{-}$[49].

Reports imply that MDHAR response to abiotic stress conditions by reducing MDHA that produces by the excess ROS scavenging, which was observed in many test species (Figure 5) $[50,51]$. The chlMDHAR is involved in photosynthetic activity during lack of peroxiredoxin [52]. In addition, chlMDAHR activity increased by three- to six-fold during pepper fruit ripening [53].

\subsection{Dehydroascorbate Reductase}

A major enzyme for GSH assisted DHA recycling is DHAR (EC 1.8.5.1), which is also known by GSH:DHA oxidoreductase or GSH dehydrogenase (AsA) [51,54]. This regeneration process is accomplished at alkaline $\mathrm{pH}$ and it is a well known biochemical reaction in plants.

The plant GSH-dependent DHAR is a monomeric enzyme, which is a member of the GSHS-transferase superfamily [55]. Arabidopsis possesses three functional DHAR encoding genes, DHAR1 (At1g19570), DHAR2 (At1g75270), and DHAR3 (At5g16710). In recent decades, the attention of researchers towards the DHAR activity in plants for regenerating DHA increased, and a number of investigations were carried out to elucidate the structure and molecular mechanism of DHAR.

The overall three-dimensional structure of DHAR from different plant origin is almost identical, except with some additional short-chain before the $\alpha 1$-helix. The enzyme has several binding sites. The G site is responsible for binding the GSH in the enzyme. The GSH cysteinyl sulfur bonded Cys20 and occupied disulfide bond. The GSH $\gamma$-glutamyl is stabilized, via $\mathrm{H}$-bonds $\mathrm{H}_{2} \mathrm{O}$ molecule, and then forms the backbone with serine (Ser) 73 and aspartic acid (Asp) 72. The Phe22 is engaged with the $\gamma$-glutamyl group by the van der Waals bond, in addition to hydrogen bonds with Lys59. The Val60 stabilizes the central cysteinyl region. The glycinyl group of GSH is loosely bound, forming a salt bridge with Lys47 [54].

The substrate-binding site or DHA binding site or H-site of DHAR enzyme typically exhibits more structural plasticity, but not simultaneously. From the structure of Pennisetum glaucum DHAR gene (PgDHAR1), it was observed that Lys8 and Asp19 are responsible for DHA binding [56]. 
The DHAR catalyzing accomplished by the following three reactions (Figure 6):

$$
\begin{gathered}
\text { DHAR-S + DHA } \rightarrow \text { DHAR-SOH + AsA (Reaction 1) } \\
\text { DHAR-SOH + GSH } \rightarrow \text { DHAR-S-SG (Reaction 2) } \\
\text { DHAR-S-SG + GSH } \rightarrow \text { DHAR-S + GSSG (Reaction 3) }
\end{gathered}
$$

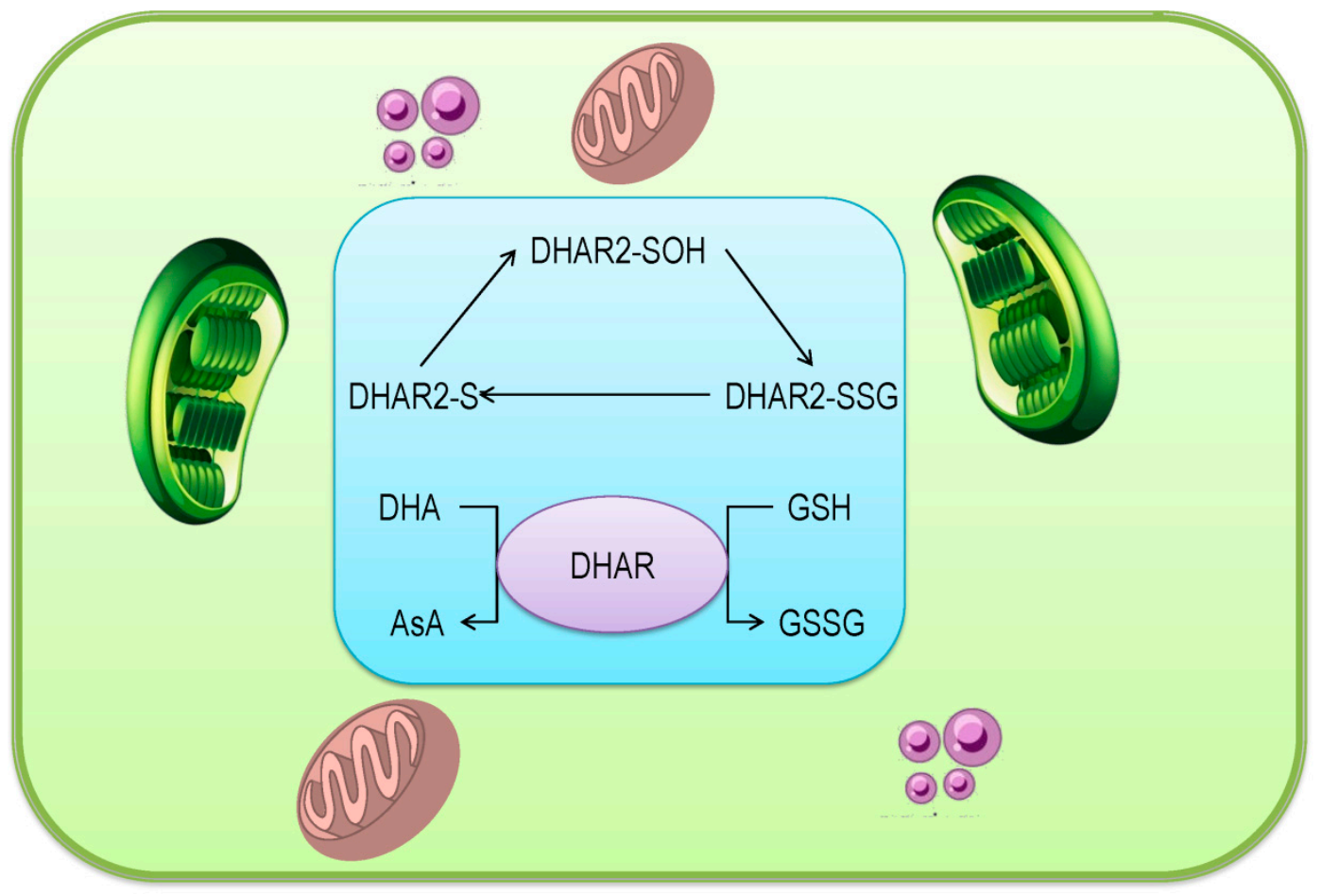

Figure 6. The mechanistic scheme, the ping-pong mechanism for the enzymatic reduction of dehydroascorbate (DHA).

Therefore, the process can be summarized by the following reaction:

$$
2 \mathrm{GSH}+\mathrm{DHA} \rightarrow \mathrm{GSSG}+\mathrm{AsA}(\text { Reaction } 4)
$$

As stated earlier, the integral function of DHAR is to reduce DHA to regenerate AsA. During this process, the active site of Cys is oxidized by DHA and further converted to the sulfenic acid. The reaction requires one molecule of $\mathrm{H}_{2} \mathrm{O}$. Knockout mutants of Arabidopsis DHAR1, DHAR2, and DHAR3, did not show any significant differences in total AsA content until facing the abiotic stress condition, which confirmed the necessity of DHAR in reducing the DHA during stress [55].

\subsection{Glutathione Reductase}

The flavoprotein oxidoreductase GR (glutathione reductase, EC 1.8.1.7) and reduced GSSG to GSH, also known by the term GSR or NADP ${ }^{+}$oxidoreductase, as it employs NADPH for its cellular activity. Although GR is stated as a dimer, the monomeric, heterodimeric, and heterotetrameric forms have also been illustrated [29].

No less than two genes that encoded GR were reported, viz. GR1 and GR2 from higher plants. Where GR1 is cytosolic or peroxisomal and shorter, contrary, GR2 comprises a long N-terminal sequence and mitochondrial or chloroplastic [57]. Up to date, several researchers reported GR isoforms in many plants, for instance, tobacco, spinach, etc. [10]. Although being found in above-stated organelles of the 
cell, the chloroplastic isoforms are accounted for $80 \%$ of GR [58]. The enzyme possesses a different quaternary structure that is based on the source from which it was purified [29].

Resembles with flavin-containing enzymes, GR exhibits the Rossmann folds, which is very much conserved and serves as the FAD and NADPH binding domains [59]. There is a controversy regarding the number of domain present in GR. Some reports suggested three, while some suggested four. Some researchers suggested an interface domain in GR protein; therefore, the enzyme has four domains, viz FAD-binding domain, NADPH-binding domain, GSSG-binding domain, and an interface domain [60]. Two Arg residues Arg287 and Arg293 are exclusively necessary for the enzymatic activity of GR [61]. Two Cys residue formed a disulfide bridge, which is redox-active and highly conserved. Serl64 replaces Cys residue in higher plants [62].

The enzyme shows high specificity to substrate binding, although the enzyme reduces GSH conjugates as well as mixed GSSG. Although Plant GR can employ NADP ${ }^{+-}$, its affinity towards NADPH is high [29]. The catalytic mechanism of GR accomplishes in two steps. The first step involves NADPH dependent reduction of the flavin moiety, which is further oxidized, meanwhile the disulfide bridge in active site reduced to form an anion-thiolate and release Cys. In the next step, GSSG molecule binds in the active site forming a disulfide bond together with a Cys and histidine (His) separately of the active site. Afterward, one GSH leaves the His, while another followed it and then leaves the Cys residue leaving the disulfide the bridge in the enzyme active site [63].

The brief reaction catalyzing by GR is as follows (Figure 7):

$$
\mathrm{GSSG}+\mathrm{NADPH}+\mathrm{H}^{+}=\mathrm{GSH}+\mathrm{NADP}^{+}
$$

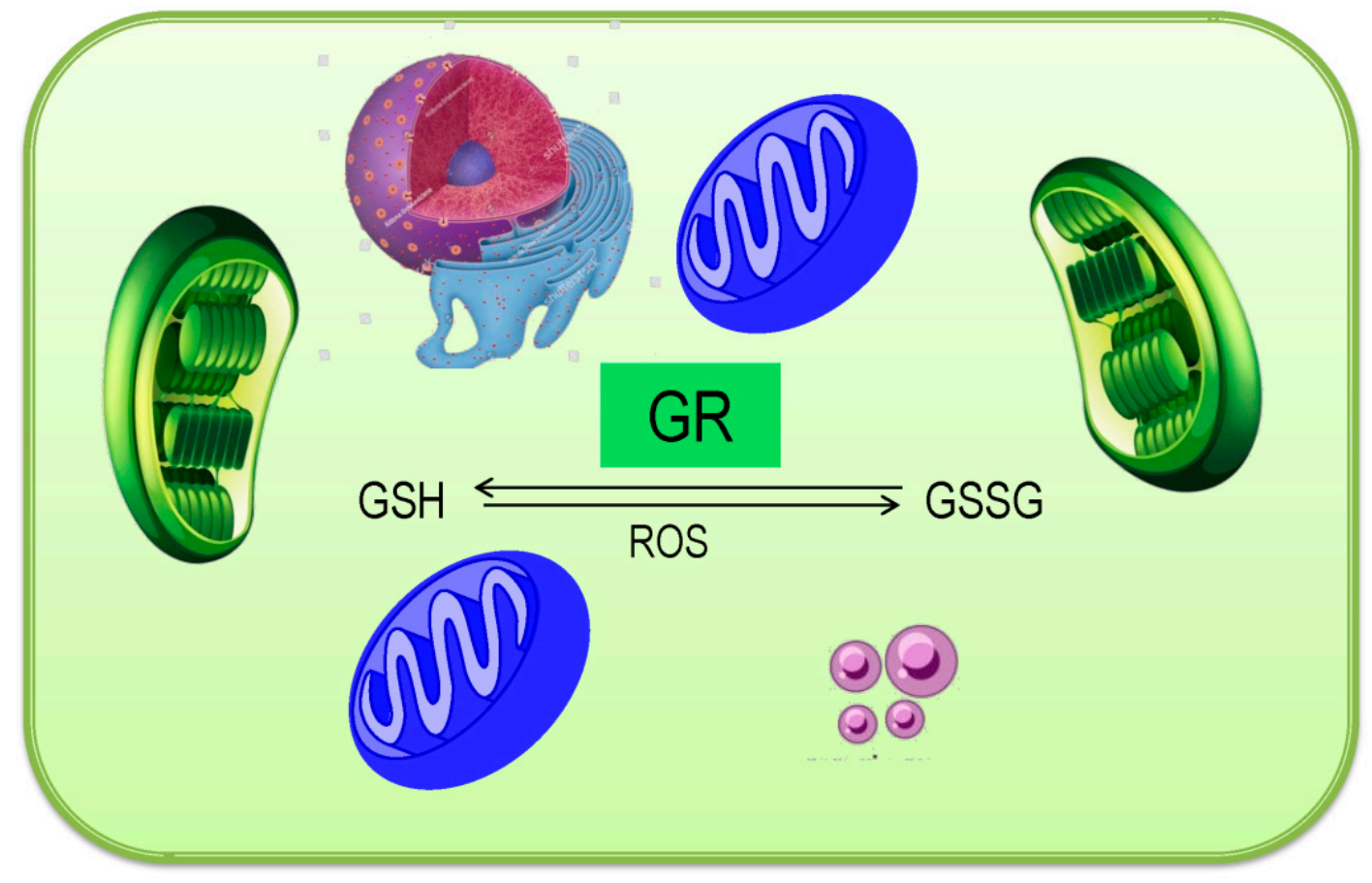

Figure 7. Mechanistic scheme for the enzymatic reduction of glutathione/oxidized glutathione (GSSG) in a plant cell.

During catalysis, $\mathrm{pH}$, and NADPH, and GSSG concentration modulate GR activity. It was reported that low NADPH concentration reduces the GR activity, while below pH 5.5 and over 7.0 is not suitable for GR actions. On the other hand, NADPH-induced GR inhibition was prevented by GSSG [64]. 


\section{Ascorbate and glutathione Redox and its Role in Plant Metabolism}

Balanced metabolism is the prerequisite for better productivity in plants, which is always disturbed due to biotic and abiotic stresses. Thus, redox balance is one of the key features of life, by which oxidized products are reduced for further oxidization and energy supply. Moreover, plant cells should counter the oxidation of vital cellular component that occurs continuously due to the presence of $21 \%$ atmospheric molecular $\mathrm{O}_{2}$, which is further complicated due to light-induced overproduction of ROS during photosynthesis. In addition, to keep the electron transport cascades active, simultaneous conversion of electron carriers between reduced and oxidized forms are required. Furthermore, photosynthetic and respiration needs regular electron flux to the electron transport chains from a different site. Therefore, the primary consequence is the generation of $\mathrm{O}_{2}{ }^{-}$and, subsequently, other ROS, from different enzyme catalysis $[10,65]$. Although playing a signaling role, over generation of ROS is harmful to cells; thus should be regulated to govern the redox homeostasis $[66,67]$. For example, AsA, GSH, tocopherols, thioredoxin, glutaredoxin, and peroxiredoxin, and energy metabolism mediators and electron carriers, for example, AsA/DHA, GSH/GSSG, FADH/FAD ${ }^{+}$, NADPH/NADP ${ }^{+}$, and $\mathrm{NAD}^{+} / \mathrm{NADH}$ play vital roles in plant cell for maintaining the redox balance and are termed as redox managers [68]. Among the redox managers, there are significant contributions drawn by AsA and GSH, hence in this section; we will discuss their role to keep redox balance as well as maintaining smooth cellular metabolism.

Reports suggested that, under control condition, the AsA/DHA ratio remains $>9$. Ascorbate becomes oxidized during ROS scavenging, electron donation to photosystem II (PSII), violaxanthin de-epoxidation, and $\alpha$-tocopherol reductive quenching $[69,70]$. While the direct reduction of MDHA by ferredoxin at photosystem I (PSI) and by MDHAR, as well as DHA reduction by GSH dependent DHAR activity, maintains a highly reduced state of AsA pool [2,71]. The biosynthesis and metabolism of AsA are discussed earlier in this article (Section 3.1). In the apoplast and vacuoles, AsA pool is an important redox buffer for ROS detoxification, where AsA recycling is mainly accomplished in the cytosol, and AsA/DHA acts as an oxidative stress sensor [72].

The GSH redox potential depends on the GSH concentration and the ratio of GSH/GSSG. In the GSH pool [GSH/GSSG], if the GSSG remains constant, but total GSH decreases, the equilibrium position dropped and redox balance is disrupted. Thus, proper judgment of the GSH/GSSG could give the idea of the redox ratio [73]. Glutathione serves in a multiplicity of metabolic functions; for instance, it participates in the regeneration of AsA from DHA in the chloroplast by DHAR [74]. Moreover, GSH plays a role in reducing glutaredoxins, functions as a precursor of phytochelatin (PC) synthesis for chelating heavy metal, signal transduction, sulfur metabolism, xenobiotics detoxification, and protects protein thiols against irreversible oxidation with disulfide formation or glutathionylation, which inhibited enzymes, like enolase and 6-phosphogluconolactonase [75]. Plant cells have distinct compartmentation of GSH. Although all other cellular compartments, except vacuole, contain GSH/GSSG redox buffer, the only vacuole is the storehouse of GSH where the GSH-conjugates are degraded [76].

As discussed in earlier (Section 2), both AsA and GSH are connected to the reactions network, the AsA-GSH pathway, and the cellular redox homeostasis depends on the pathway components [76]. In this cycle, AsA performs electron donation for APX that works for $\mathrm{H}_{2} \mathrm{O}_{2}$ detoxification. Due to its high attraction for $\mathrm{H}_{2} \mathrm{O}_{2}$, APX is capable of efficient ROS scavenging, even in a low concentration, which gives rise to DHA. The produced DHA is further recycled back, which maintains a high ratio of AsA/DHA. If DHA cannot reduce, it might further be irreversibly hydrolyzed, which decreases the ability of AsA redox pool [77]. In the catalysis process GSSG produced, which is further recycled back, which maintains not only a high GSH/GSSG ratio, but also the balance between GSH and AsA pools [10].

In addition, the redox couples of AsA/DHA and GSH/GSSG can also function in another way for accomplishing redox signaling [78]. As discussed earlier, the AsA/DHA couples create redox balance inside cells. Moreover, AO converts AsA to DHA in the apoplast [79], and it creates a redox 
gradient to connect intra- and extra-cellular atmosphere transverse the plasma membrane. Hence, AsA/DHA redox pair functions in apoplastic and cytoplasmic signals [80]. In contrast, the GSH/GSSG couple plays their functions in balancing intracellular redox potential, which in the intracellular redox signaling [81]. In this regard, the GSH distribution in different cellular organelle is very important for understanding cellular redox situation, for which signaling, as well as cellular metabolism, are smoothly going on [12].

\section{Overview of Oxidative Stress and Antioxidant Defense in Plants}

The production of ROS in living organisms is a usual cellular metabolism, and it is found in a large number in the internal constituents of the cell-like chloroplast, mitochondria, cytosol, peroxisomes, etc. [82-84].

Each plant cell maintains a dynamic balance between ROS and ROS-scavenging antioxidants. Abiotic stress destroys such cellular balance in favor of oxidative reactions by producing a huge amount of ROS [85]. Insufficient energy indulgence in the photosynthetic process during abiotic stresses reduces molecular oxygen and then produces a large amount of ROS, including $\mathrm{H}_{2} \mathrm{O}_{2}, \mathrm{O}_{2}{ }^{-}$, ${ }^{1} \mathrm{O}_{2}, \mathrm{OH}^{\bullet}$, and so on (Figure 8) $[10,86]$. Reactive oxygen species are extremely reactive molecules and they can damage a large variety of cellular biomolecules, including carbohydrates, nucleic acids, lipids, proteins, etc., and alter their functions [85,87]. In addition, MG, a cytotoxic compound and reactive oxidizer, spontaneously produced in a cell in little amount but under abiotic stresses, its production increased and participated in developing oxidative stress (Figure 8). Similar to ROS, MG production is increased under abiotic stress, which can damage the ultra-structural constituents of cell and cause mutation, and ultimately provokes programmed cell death (PCD) [10].

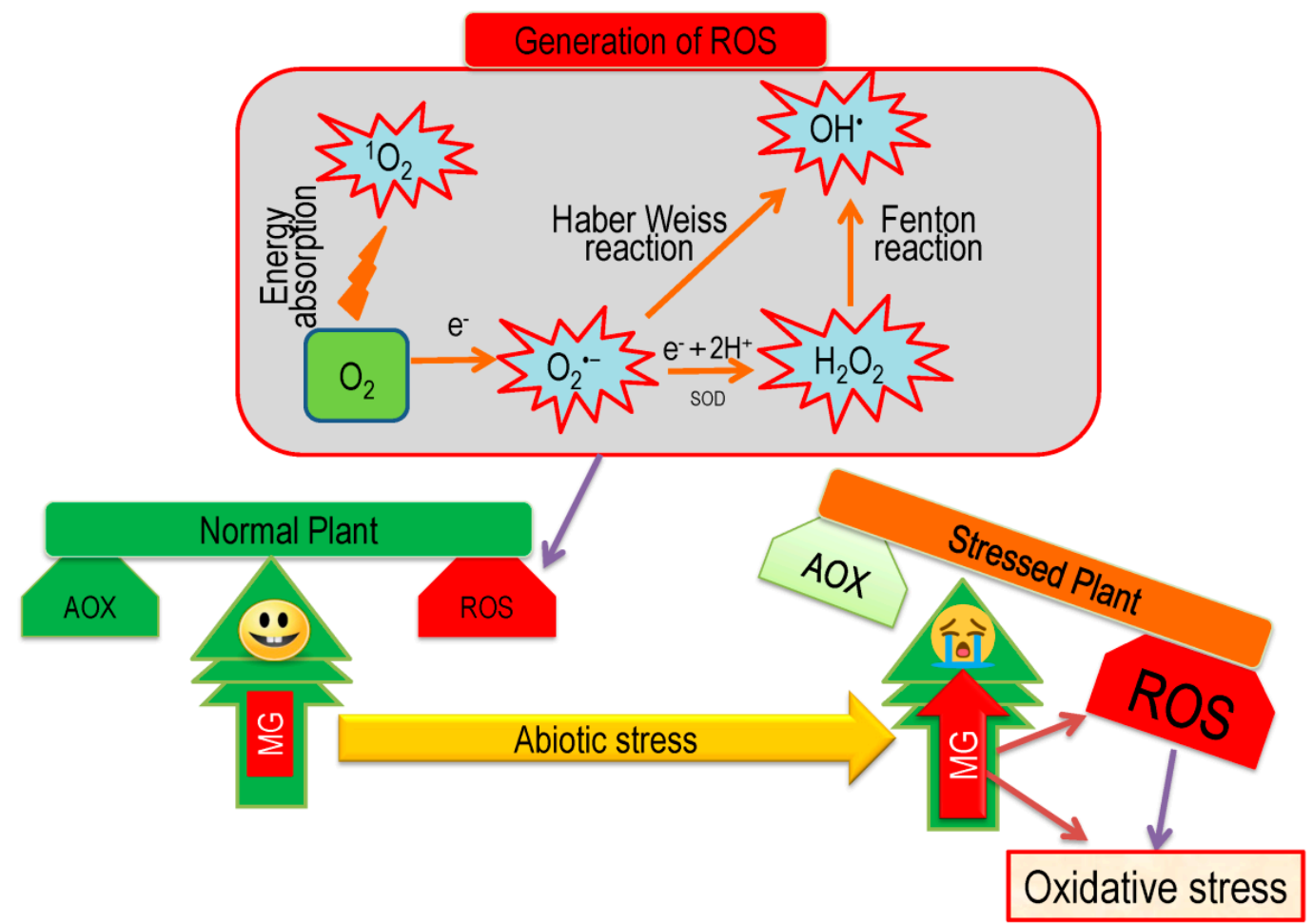

Figure 8. Abiotic stress-induced oxidative stress through the generation of ROS. Additional details are in the text.

Besides causing oxidative stress, ROS and MG play signaling roles for stress tolerance, which controls acclimation and defense responses by modulating some antioxidants and their respective 
genes $[10,86]$. The excess generation of ROS and MG is also able to activate interruption in redox homeostasis, which can give the signal for cellular death or shortening plant life cycle [10,82].

Plant cells have well established antioxidant defense and glyoxalase system for scavenging toxic ROS and MG, respectively. The antioxidant defense system consists of some non-enzymatic components (AsA, GSH, alkaloids, $\alpha$-tocopherol, non-protein amino acids, and phenolic compounds) and enzymatic components (SOD, CAT, APX, MDHAR, DHAR, GR, GST, and GPX [5,28]). Within the antioxidant defense system, the AsA-GSH pool performs the direct and significant role for minimizing stress effect through scavenging of ROS by using key four enzymes, e.g. APX, MDHAR, DHAR, and GR $[28,88,89]$. In our previous section (Section 3.3, 3.4, 3.5, and 3.6), we elaborately discussed the function of these four enzymes in ROS detoxification. Usually, in the antioxidant defense system, SOD gives frontline protection against ROS by converting $\mathrm{O}_{2}{ }^{-}$to $\mathrm{H}_{2} \mathrm{O}_{2}$. Subsequently, CAT and APX scavenge $\mathrm{H}_{2} \mathrm{O}_{2}$ to $\mathrm{H}_{2} \mathrm{O}$. Glutathione peroxidase and GST also scavenge $\mathrm{H}_{2} \mathrm{O}_{2}$ to $\mathrm{H}_{2} \mathrm{O}$ with the help of GSH (Figure 9) [28].

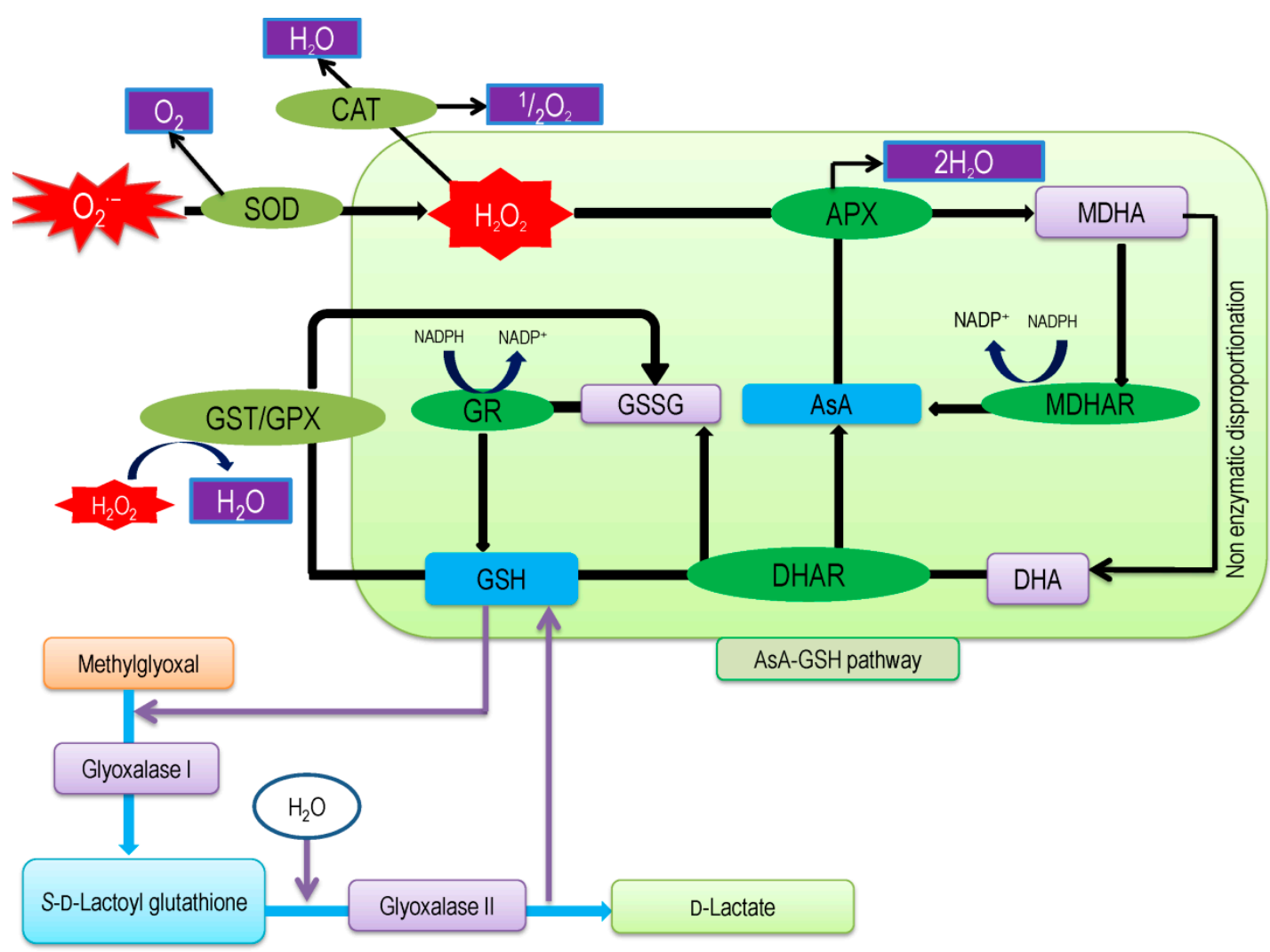

Figure 9. AsA-GSH pathway of the antioxidant defense system and its relation with the glyoxalase system. Additional details are in the text.

Toxic MG is detoxified in the cell by glyoxalase system. Glutathione is not only the major element of AsA-GSH cycle, but it also plays a significant function in the MG detoxification system. Glyoxalase system is composed of two vital enzymes, Gly I and Gly II. In glyoxalase system, MG is detoxified to non-toxic compound in two steps reactions; in the initial step, MG is transformed to $S$-D-lactoyl-glutathione through the utilization of GSH and in the final step S-D-lactoyl-glutathione transformed in to D-Lactate, where GSH is recycled back [11]. Moreover, GSH contributes to metal chelation. It enhances the amount of PC under stress condition, which makes a complex with metal and drives into the cell vacuole as inert form [90]. 


\section{Role of AsA-GSH in Regulating Oxidative Stress under Abiotic Stresses}

Abiotic stress-induced excess ROS causes oxidative stress in plants followed by cellular damage, even death. Hence, the plant itself defends against this higher ROS accumulation by their defense mechanism. Plant significantly activates the AsA-GSH pathway for ROS detoxification. In this section, we will discuss the involvement of AsA-GSH cycle for alleviating oxidative stress upon various abiotic stresses reviewing recently published articles (Tables $1-3$ ).

\subsection{Salinity}

One of the most devastating abiotic stress factors-salinity by which cultivable land is becoming barren thus reduces total crop production day by day. Oxidative stress is the most dangerous event under salt inundation is imposed by salinity-induced ionic and osmotic stress [10]. Hence, these ionic and osmotic stress both disturb the photosystem, and thus cause excess ROS, such as ${ }^{1} \mathrm{O}_{2}, \mathrm{O}_{2}{ }^{-}, \mathrm{H}_{2} \mathrm{O}_{2}$, and $\mathrm{OH}$. Salinity-persuaded acute ROS accumulations, then bother cellular redox followed by cellular damage counting membrane dysfunction, DNA damage, collapse the enzymatic action, along with distraction of the antioxidant defense system [91,92]. At this point, the plant synthesizes cellular AsA and GSH, which act as non-enzymatic antioxidants by involving their enzymatic components to detoxify ROS up to tolerable levels (Table 1).

However, the enzymes of AsA-GSH pathway showed their differential responses intolerant and sensitive varieties due to saline toxicity. Among salt-tolerant (Pokkali) and sensitive (BRRI dhan29) rice cultivars. Pokkali responded by enhancing the enzymatic activities of the AsA-GSH cycle, where, lowered APX and higher DHAR activity along with unchanged MDHAR and GR activities were found from BRRI dhan29. Rahman et al. [91,93] reported about the well involvement of AsA-GSH cycle in salt-stressed $O$. sativa where ROS generation was extreme. Here, salt exposed rice enhanced the reduced and oxidized GSH content with a lesser amount of AsA by the higher APX, MDHAR, DHAR, and GR activities against overproduced ROS. Vigna radiata was grown under the saline condition [94] and where salt-induced oxidative stress was marked with extreme $\mathrm{O}_{2}{ }^{-}$and $\mathrm{H}_{2} \mathrm{O}_{2}$ overgeneration. Salt-stressed $V$. radiata augmented GSH and GSSG contents along with lowered AsA, whereas up-regulated the activity of all enzymatic antioxidants of AsA-GSH cycle and thus responded with elevated ROS [95]. Salt exposed Lens culinaris up-stimulated both MDHAR and DHAR activities, which resulted in a lesser amount of AsA and indicated the overproduced $\mathrm{H}_{2} \mathrm{O}_{2}$ detoxification [96]. Recently, Singh et al. [97] disclosed the incremental activity of enzymatic antioxidants, including APX, DHAR, and GR, with lower AsA, GSH, and GSSG contents, because of salt-induced higher ROS accumulation in Solanum lycopersicum. Similarly, $150 \mathrm{mM}$ salt-treated S. lycopersicum also decreased AsA content, which might be used in $\mathrm{H}_{2} \mathrm{O}_{2}$ detoxification, while better GSH showed its role in lowering $\mathrm{H}_{2} \mathrm{O}_{2}$. Ahmad et al. [98] also observed higher APX, and GR activities, while MDHAR and DHAR activities again reduced as well as supported AsA-GSH mediated ROS regulation. Ahanger et al. [99] reported the same response of S. lycopersicum upon saline toxicity. Both activities of APX and GR were enhanced in salt-treated Triticum aestivum besides elevated $\mathrm{H}_{2} \mathrm{O}_{2}$ generation and resulted in higher GSH accumulation [100]. The activity of APX, MDHAR, DHAR, and GR enhanced in salt-stressed S. lycopersicum to check the excessive $\mathrm{H}_{2} \mathrm{O}_{2}$ generation, which resulted in lowered AsA and GSH contents [92].

The changes in AsA-GSH pathway were investigated in salt-stressed Nitraria tangutorum by applying a varied level of $\mathrm{NaCl}(100,200,300$, and $400 \mathrm{mM})$ [101]. They noticed a gradual enhancement of AsA, DHA, GSH, and GSSG contents by keeping pace with sequential increment of salt-induced $\mathrm{H}_{2} \mathrm{O}_{2}$. Here, increased MDHAR and DHAR activities in stressed seedlings also contributed to increasing AsA, and higher DHAR and GR were responsible for better GSH and GSSG contents [92,102]. Talaat et al. corroborated these results with salt-exposed Phaseolus vulgaris [103]. Thus, as a part of plant antioxidant defense under salinity, AsA-GSH pathway is very efficient to regulate extra ROS for being tolerant. 


\subsection{Drought}

Drought is another most important abiotic stress, which generates excess ROS accumulation and thus causes variation in the enzymatic activities of AsA-GSH pathway for ROS detoxification. The enzymatic responses of AsA-GSH pathways varied, depending upon plant species, plant age, drought intensity, and duration [10]. Commonly, drought up-regulated the enzymatic antioxidant activities of AsA-GSH pool $[10,104]$. Plant tolerance to drought stress is categorized based on stress-induced endogenous antioxidants contents along with enzymatic activities (Table 2). Dendranthema grandiflorum responded differentially according to their tolerant and sensitive varieties, where tolerant one comparatively displayed better enzyme activity of antioxidants than sensitive [105]. Lou et al. [106] demonstrated how T. aestivum responded upon drought exposure. Hence, they noticed that the AsA-GSH cycle responded considerably with excess ROS generation by significant variation of GSH/GSSG and AsA/DHA redox along with the steady increment of $\mathrm{H}_{2} \mathrm{O}_{2}$. Their team also observed the enzymatic up-stimulation of AsA-GSH pathway to alleviate stress by scavenging excess ROS in T. aestivum spike. Thus, T. aestivum showed higher participation of AsA with higher APX activity in drought exposure for scavenging extra $\mathrm{H}_{2} \mathrm{O}_{2}$, as well as higher enzymatic activity to run the AsA-GSH pathway systematically [107].

Table 1. Role of AsA-GSH in regulating oxidative stress under salinity and drought.

\begin{tabular}{|c|c|c|c|c|}
\hline Plant Species & Stress Levels & Status of AsA-GSH Component(s) & ROS Regulation & References \\
\hline Triticum aestivum $\mathrm{L}$. & $100 \mathrm{mM} \mathrm{NaCl}$ & $\begin{array}{l}\text { GSH content increased by } 15 \% \text {; } \\
\text { Stimulated APX and GR activities } \\
\text { by } 78 \% \text { and } 56 \% \text {, respectively }\end{array}$ & $\begin{array}{c}\text { Increased } \mathrm{H}_{2} \mathrm{O}_{2} \\
\text { content about } 79 \%\end{array}$ & [100] \\
\hline $\begin{array}{l}\text { T. aestivum L. cv. } \\
\text { BARI Gom-21 }\end{array}$ & $\begin{array}{c}12 \% \text { PEG for } 48 \\
\text { and } 72 \mathrm{~h}\end{array}$ & $\begin{array}{l}\text { Decreased AsA content at } 48 \text { h, but } \\
\text { after } 72 \text { h, AsA content again } \\
\text { enhanced; Increased GSH and } \\
\text { GSSG content where GSH/GSSG } \\
\text { ratio decreased time-dependently; } \\
\text { Enhanced the activities of APX, } \\
\text { MDHAR, and GR }\end{array}$ & $\begin{array}{l}\text { Enhanced the } \\
\mathrm{H}_{2} \mathrm{O}_{2} \text { content by } \\
62 \% \text { and increased } \\
\mathrm{O}_{2}{ }^{-} \text {accumulation }\end{array}$ & [113] \\
\hline T. aestivum L. & $10 \%$ PEG & $\begin{array}{c}\text { Reduced AsA/DHA and GSH/GSSG } \\
\text { redox; Increased enzymatic } \\
\text { antioxidants actions of AsA-GSH } \\
\text { cycle }\end{array}$ & $\begin{array}{c}\text { Increased } \mathrm{H}_{2} \mathrm{O}_{2} \\
\text { production }\end{array}$ & {$[107]$} \\
\hline T. aestivum L. & $\begin{array}{c}35-40 \% \text { field } \\
\text { capacity }(\mathrm{FC}) \text { water }\end{array}$ & $\begin{array}{l}\text { Increased GSH/GSSG by } 64 \% \text { while } \\
\text { decreased AsA/DHA by } 52 \% \\
\text { respective with a duration of stress; } \\
\text { Enhanced APX, MDHAR, DHAR } \\
\text { and GR activities }\end{array}$ & $\begin{array}{l}\text { Increased } \mathrm{H}_{2} \mathrm{O}_{2} \\
\text { along with stress } \\
\text { duration }\end{array}$ & {$[106]$} \\
\hline $\begin{array}{l}\text { T. aestioum cv. } \\
\text { Pradip }\end{array}$ & $\begin{array}{c}150 \text { and } 300 \mathrm{mM} \\
\mathrm{NaCl}\end{array}$ & $\begin{array}{l}\text { Reduced AsA content upto 52\%; } \\
\text { Increased reduced and oxidized } \\
\text { GSH accumulation by } 55 \% \text { and } 18 \% \text {, } \\
\text { respectively with } 32 \% \text { higher } \\
\text { GSH/GSSG ratio; Increased APX } \\
\text { activity with } 29 \% \text { reduction of GR } \\
\text { activity; Slightly increased MDHAR } \\
\text { and DHAR activity }\end{array}$ & $\begin{array}{c}\text { Enhanced } \mathrm{H}_{2} \mathrm{O}_{2} \\
\text { generation by } 60 \%\end{array}$ & [28] \\
\hline $\begin{array}{l}\text { Oryza sativa L. cv. } \\
\text { BRRI dhan } 47\end{array}$ & $150 \mathrm{mM} \mathrm{NaCl}$ & $\begin{array}{c}\text { Increased GSH accumulation while } \\
\text { reduced AsA content by } 49 \% \\
\text { Increased GSH content and lowered } \\
\text { the redox status of both AsA/DHA } \\
\text { and GSH/GSSG; Upregulated the } \\
\text { activity of APX, MDHAR, DHAR, } \\
\text { and GR }\end{array}$ & $\begin{array}{l}\text { Increased the } \\
\text { production of } \mathrm{O}_{2}^{-} \\
\text {with } 82 \% \text { higher } \\
\qquad \mathrm{H}_{2} \mathrm{O}_{2} \\
\text { accumulation }\end{array}$ & [93] \\
\hline
\end{tabular}


Table 1. Cont.

\begin{tabular}{|c|c|c|c|c|}
\hline Plant Species & Stress Levels & Status of AsA-GSH Component(s) & ROS Regulation & References \\
\hline $\begin{array}{l}\text { O. sativa L. cv. } \\
\text { BRRI dhan } 49\end{array}$ & $300 \mathrm{mM} \mathrm{NaCl}$ & $\begin{array}{c}\text { Reduced AsA and GSH } \\
\text { accumulation by } 51 \% \text { and } 57 \% \text {, } \\
\text { respectively; Decrease GSH/GSSG } \\
\text { redox by } 87 \% \text {; Showed lowered } \\
\text { APX ( } 27 \%), \text { MDHAR }(24 \%), \text { DHAR } \\
\text { and GR }(25 \%) \text { activities }\end{array}$ & $\begin{array}{c}\text { Increased } \mathrm{H}_{2} \mathrm{O}_{2} \\
\text { content upto } 69 \%\end{array}$ & [114] \\
\hline $\begin{array}{l}\text { O. sativa L. cv. } \\
\text { BRRI dhan } 54\end{array}$ & $300 \mathrm{mM} \mathrm{NaCl}$ & $\begin{array}{l}\text { Improved AsA content by } 51 \% \text { with } \\
\text { higher GSH content; Decreased } \\
\text { GSH/GSSG ratio by } 53 \% \text {; Showed } \\
\text { higher APX ( } 27 \%) \text { and DHAR } \\
\text { activities while decreased both GR } \\
(23 \%) \text { and MDHAR activities }\end{array}$ & $\begin{array}{c}\text { Accumulated } 63 \% \\
\text { higher } \mathrm{H}_{2} \mathrm{O}_{2} \\
\text { content }\end{array}$ & [114] \\
\hline $\begin{array}{c}\text { Brassica napus L. cv. } \\
\text { BINA sharisha } 3\end{array}$ & 100 and $\mathrm{mM} \mathrm{NaCl}$ & $\begin{array}{c}\text { Reduced the AsA content by } 22 \% \text {; } \\
\text { Increased GSH content by } 72 \% \text { and } \\
\text { GSSG content by } 88 \% \text {; Unaltered the } \\
\text { GSH/GSSG ratio; Amplified APX } \\
\text { activity by } 32 \% \text {, decreased DHAR } \\
\text { activity by } 17 \% \text {; Slightly increased } \\
\text { GR activity }\end{array}$ & $\begin{array}{c}\text { Accumulated } \\
\text { higher } \mathrm{H}_{2} \mathrm{O}_{2} \\
\text { content by } 76 \%\end{array}$ & [115] \\
\hline $\begin{array}{l}\text { B. napus L. cv. } \\
\text { BINA sharisha } 3\end{array}$ & $200 \mathrm{mM} \mathrm{NaCl}$ & $\begin{array}{l}\text { Reduced the AsA content (40\%) } \\
\text { along with increased GSH ( } 43 \%) \\
\text { and GSSG (136\%) contents; } \\
\text { Decreased the GSH/GSSG ratio } \\
(40 \%) \text {; Amplified the APX activity } \\
(39 \%) \text { and reduced the MDHAR } \\
(29 \%) \text { and DHAR }(35 \%) \text { activities; } \\
\text { Improved GR activity }(18 \%)\end{array}$ & $\begin{array}{c}\text { Showed } 90 \% \text { more } \\
\mathrm{H}_{2} \mathrm{O}_{2} \text { content }\end{array}$ & [115] \\
\hline B. napus L. & $15 \%$ PEG & $\begin{array}{l}\text { The AsA accumulation remained } \\
\text { unaltered and reduced the } \\
\text { AsA/DHA ratio; Enhanced GSH } \\
\text { content by } 19 \% \text { and GSSG by } 67 \% \\
\text { and decreased GSH/GSSG ratio; } \\
\text { Increased APX, MDHAR, DHAR } \\
\text { and GR activities }\end{array}$ & $\begin{array}{c}\text { Higher } \\
\text { accumulation of } \\
\mathrm{H}_{2} \mathrm{O}_{2} \text { by } 55 \%\end{array}$ & [116] \\
\hline B. campestris L. & $15 \%$ PEG & $\begin{array}{l}\text { Decreased AsA content by } 27 \% \text { with } \\
\text { a decrease of AsA/DHA ratio; } \\
\text { Increased GSH content by } 33 \% \text { with } \\
\text { higher GSSG content by } 79 \% \text { and } \\
\text { lowered GSH/GSSG ratio; } \\
\text { Decreased DHAR activity }\end{array}$ & $\begin{array}{c}\text { Higher } \\
\text { accumulation of } \\
\mathrm{H}_{2} \mathrm{O}_{2} \text { about } 109 \%\end{array}$ & [116] \\
\hline B. juncea L. & $15 \%$ PEG & $\begin{array}{l}\text { Increased the AsA content and did } \\
\text { not affect the AsA/DHA ratio; } \\
\text { Increased GSH content by } 48 \% \text { and } \\
\text { GSSG by } 83 \% \text { and decreased } \\
\text { GSH/GSSG ratio; Increased APX, } \\
\text { MDHAR, DHAR and GR activities }\end{array}$ & $\begin{array}{l}\text { Accumulation of } \\
37 \% \text { higher } \mathrm{H}_{2} \mathrm{O}_{2}\end{array}$ & [116] \\
\hline $\begin{array}{l}\text { B. juncea L. cv. } \\
\text { BARI Sharisha } 11\end{array}$ & $10 \%$ PEG & $\begin{array}{l}\text { Reduced AsA content }(14 \%) \text { while } \\
\text { increased both GSH (32\%) and } \\
\text { GSSG }(48 \%) \text { contents; Enhanced } \\
\text { APX activity (24\%); Decreased } \\
\text { MDHAR and DHAR (33\%) } \\
\text { activities along with } 31 \% \text { increased } \\
\text { GR activity }\end{array}$ & $\begin{array}{l}\text { Acute generation } \\
\text { of } \mathrm{H}_{2} \mathrm{O}_{2}(41 \%)\end{array}$ & [117] \\
\hline $\begin{array}{l}\text { B. juncea L. cv. } \\
\text { BARI Sharisha } 11\end{array}$ & $20 \%$ PEG & $\begin{array}{c}\text { Decreased AsA content by } 34 \% \\
\text { while increased the content of GSH } \\
\text { by } 25 \% \text { and GSSG by } 101 \% \text {; } \\
\text { Up-regulated APX activity by } 33 \% \text {; } \\
\text { Decreased activity of MDHAR and } \\
\text { DHAR }(30 \%)\end{array}$ & $\begin{array}{l}\text { Extreme generation } \\
\text { of } \mathrm{H}_{2} \mathrm{O}_{2} \text { by } 95 \%\end{array}$ & [117] \\
\hline
\end{tabular}


Table 1. Cont.

\begin{tabular}{|c|c|c|c|c|}
\hline Plant Species & Stress Levels & Status of AsA-GSH Component(s) & ROS Regulation & References \\
\hline $\begin{array}{l}\text { B. napus L. cv. } \\
\text { BINA Sarisha } 3\end{array}$ & $10 \%$ PEG & $\begin{array}{c}\text { Increased AsA ( } 21 \%) \text {, GSH ( } 55 \%) \\
\text { and GSSG contents while decreased } \\
\text { GSH/GSSG ratio Unaltered the } \\
\text { activities of APX, and increased the } \\
\text { activity of MDHAR, DHAR, and GR } \\
(26 \%)\end{array}$ & $\begin{array}{l}\text { Elevated the } \mathrm{H}_{2} \mathrm{O}_{2} \\
\text { production }\end{array}$ & [11] \\
\hline $\begin{array}{l}\text { B. napus L. cv. } \\
\text { BINA Sarisha } 3\end{array}$ & $20 \%$ PEG & $\begin{array}{l}\text { Unaltered AsA content along with } \\
\text { higher content of GSH ( } 46 \% \text { ) and } \\
\text { GSSG and reduced GSH/GSSG ratio; } \\
\text { Reduced the APX and MDHAR } \\
\text { activities along with the higher } \\
\text { activity of DHAR and GR }(23 \%)\end{array}$ & $\begin{array}{l}\text { Showed higher } \\
\mathrm{H}_{2} \mathrm{O}_{2} \text { production }\end{array}$ & {$[11]$} \\
\hline $\begin{array}{l}\text { B. napus L.cv. } \\
\text { BINA sharisha } 3\end{array}$ & $10 \%$ PEG & $\begin{array}{l}\text { Increased AsA, GSH (31\%) and } \\
\text { GSSG (83\%) accumulation with } \\
\text { lowered GSH/GSSG ratio; Increased } \\
\text { APX activity while reduced } \\
\text { MDHAR and DHAR activities, but } \\
\text { GR activity remained unaltered }\end{array}$ & $\begin{array}{l}\text { Increased } \mathrm{H}_{2} \mathrm{O}_{2} \\
\text { content by } 53 \%\end{array}$ & {$[52]$} \\
\hline $\begin{array}{l}\text { B. napus L. cv. } \\
\text { BINA Sharisha } 3\end{array}$ & $20 \%$ PEG & $\begin{array}{l}\text { Slightly increased AsA content with } \\
26 \% \text { and } 225 \% \text { increase of GSH and } \\
\text { GSSG content, respectively; } \\
\text { Reduced GSH/GSSG ratio; } \\
\text { Increased APX activity while } \\
\text { decreased the activity of MDHAR, } \\
\text { DHAR, and GR }(30 \%)\end{array}$ & $\begin{array}{c}\text { Increased about } \\
93 \% \mathrm{H}_{2} \mathrm{O}_{2} \text { content }\end{array}$ & [52] \\
\hline $\begin{array}{l}\text { B. rapa L. cv. BARI } \\
\text { Sharisha- } 15\end{array}$ & $20 \%$ PEG & $\begin{array}{l}\text { Slightly increased AsA content with } \\
72 \% \text { and } 178 \% \text { increase of GSH and } \\
\text { GSSG content, respectively; } \\
\text { Reduced GSH/GSSG ratio by } 38 \% ; \\
\text { Increased APX, MDHAR, DHAR, } \\
\text { and GR activity }\end{array}$ & $\begin{array}{c}\text { Increased about } \\
131 \% \mathrm{H}_{2} \mathrm{O}_{2} \text { content }\end{array}$ & [104] \\
\hline $\begin{array}{l}\text { Cucumis melo L. cv. } \\
\text { Yipintianxia No. } \\
208\end{array}$ & $\begin{array}{c}50 \mathrm{mM} \text { of } \\
\mathrm{NaCl}: \mathrm{Na}_{2} \mathrm{SO}_{4}: \\
\mathrm{NaHCO}_{3}: \mathrm{Na}_{2} \mathrm{CO}_{3} \\
(1: 9: 9: 1 \mathrm{M})\end{array}$ & $\begin{array}{c}\text { Improved AsA, GSSG and DHA } \\
\text { contents; Lowered GSH content; } \\
\text { Reduced the ratio of AsA/DHA and } \\
\text { GSH/GSSG; Stimulated the activity } \\
\text { of APX by } 96 \% \text { and DHAR by } 38 \% \\
\text { while reducing the activity of } \\
\text { MDHAR and GR by } 48 \% \text { and } 34 \% \text {, } \\
\text { respectively }\end{array}$ & $\begin{array}{c}\text { Increased } \mathrm{H}_{2} \mathrm{O}_{2} \\
\text { accumulation }\end{array}$ & [118] \\
\hline $\begin{array}{l}\text { Solanum } \\
\text { lycopersicum L., var. } \\
\text { Lakshmi }\end{array}$ & $\begin{array}{c}0.3 \text { and } 0.5 \mathrm{~g} \mathrm{NaCl} \\
\mathrm{kg}^{-1} \text { soil }\end{array}$ & $\begin{array}{l}\text { Reduced AsA and AsA/DHA ratio; } \\
\text { Lowered GSH and GSSG } \\
\text { accumulation with decreased } \\
\text { GSH/GSSG redox; Increased APX } \\
\text { activity by } 28 \% \text {, DHAR activity by } \\
28 \% \text { and GR activity by } 14 \%\end{array}$ & $\begin{array}{l}\text { Enhanced } \mathrm{H}_{2} \mathrm{O}_{2} \\
\text { and } \mathrm{O}_{2}^{-} \\
\text {accumulation }\end{array}$ & [97] \\
\hline $\begin{array}{c}\text { S. lycopersicum L.cv. } \\
\text { Boludo }\end{array}$ & $\begin{array}{l}60 \mathrm{mM} \mathrm{NaCl}, \\
30 \text { days }\end{array}$ & $\begin{array}{c}\text { Reduced the activities of APX, } \\
\text { DHAR, and GR; Increased MDHAR } \\
\text { activity }\end{array}$ & $\begin{array}{c}\text { Higher } \mathrm{H}_{2} \mathrm{O}_{2} \\
\text { generation }\end{array}$ & [119] \\
\hline $\begin{array}{l}\text { S. lycopersicum L. } \\
\text { var. Pusa Ruby }\end{array}$ & $150 \mathrm{mM} \mathrm{NaCl}$ & $\begin{array}{c}\text { Decreased AsA and GSH content } \\
\text { with a higher content of DHA and } \\
\text { GSSG; Increased APX, MDHAR, } \\
\text { DHAr and GR activities }\end{array}$ & $\begin{array}{l}\text { Higher generation } \\
\text { of } \mathrm{H}_{2} \mathrm{O}_{2} \text { and } \mathrm{O}_{2}^{-}\end{array}$ & [92] \\
\hline $\begin{array}{l}\text { S. lycopersicum L. } \\
\text { var. Pusa Rohini }\end{array}$ & $150 \mathrm{mM} \mathrm{NaCl}$ & $\begin{array}{l}\text { Reduced AsA content by } 42 \% \text {; } \\
\text { Increased both GSH and GSSG } \\
\text { accumulation; Enhanced the activity } \\
\text { of APX and GR by } 86 \% \text { and } 29 \% \text {, } \\
\text { respectively with reduction of the } \\
\text { activity of MDHAR and DHAR by } \\
38 \% \text { and } 32 \% \text {, respectively }\end{array}$ & $\begin{array}{l}\text { Accumulated } \\
\text { about } 3 \text { fold higher } \\
\mathrm{H}_{2} \mathrm{O}_{2} \text { content }\end{array}$ & [99] \\
\hline
\end{tabular}


Table 1. Cont.

\begin{tabular}{|c|c|c|c|c|}
\hline Plant Species & Stress Levels & Status of AsA-GSH Component(s) & ROS Regulation & References \\
\hline $\begin{array}{l}\text { S. lycopersicon L. } \\
\text { cv.K-21 }\end{array}$ & $150 \mathrm{mM} \mathrm{NaCl}$ & $\begin{array}{l}\text { Reduced AsA content by } 40 \% \text { with } \\
50 \% \text { higher GSH content; Lowered } \\
\text { GSSG content by } 23 \% \text { while } \\
\text { increased GSH/GSSG ratio by } 112 \% \text {; } \\
\text { Increased APX ( } 86 \% \text { ) and GR }(92 \%) \\
\text { activity along with the lowered } \\
\text { activity of MDHAR }(32 \%) \text { and } \\
\text { DHAR }(30 \%)\end{array}$ & $\begin{array}{c}\text { Elevated } \mathrm{H}_{2} \mathrm{O}_{2} \\
\text { content about } 175 \%\end{array}$ & [98] \\
\hline $\begin{array}{l}\text { Nitraria Tangutorum } \\
\text { Bobr. }\end{array}$ & $\begin{array}{c}100,200,300 \text { and } \\
400 \mathrm{mM} \mathrm{NaCl}\end{array}$ & $\begin{array}{l}\text { Increased AsA, DHA, GSH and } \\
\text { GSSG accumulation decreased their } \\
\text { redox status; Enhanced the activity } \\
\text { of APX and GR; Unvaried the } \\
\text { activity of DHAR and MDHAR but } \\
\text { increased DHAR activity only at } \\
\quad 300 \mathrm{mM} \mathrm{NaCl}\end{array}$ & $\begin{array}{l}\text { Increased } \mathrm{O}_{2}^{-} \text {and } \\
\mathrm{H}_{2} \mathrm{O}_{2} \text { content by } \\
38-98 \text { and } 49-102 \% \\
\text { respectively }\end{array}$ & [101] \\
\hline $\begin{array}{l}\text { Camellia sinensis (L.) } \\
\text { O.Kuntze }\end{array}$ & $300 \mathrm{mM} \mathrm{NaCl}$ & $\begin{array}{l}\text { Enhanced the AsA and GSH } \\
\text { content; Increased APX activity }\end{array}$ & $\begin{array}{c}\text { Elevated } \mathrm{H}_{2} \mathrm{O}_{2} \text { and } \\
\mathrm{O}_{2}{ }^{-} \text {content }\end{array}$ & [120] \\
\hline $\begin{array}{l}\text { Phaseolus vulgaris L. } \\
\text { cv. Nebraska }\end{array}$ & $\begin{array}{l}2.5 \text { and } 5.0 \mathrm{dS} \mathrm{m}^{-1} \\
\text { prepared from a } \\
\text { mixture of } \mathrm{NaCl} \text {, } \\
\mathrm{CaCl}_{2} \text {, and } \mathrm{MgSO}_{4}\end{array}$ & $\begin{array}{c}\text { Increased AsA, GSH, DHA and } \\
\text { GSSG accumulations; Enhanced } \\
\text { AsA/DHA and GSH/GSSG status; } \\
\text { Stimulated the enzymatic activity of } \\
\text { APX, MDHAR, DHAR and GR } \\
\text { activities }\end{array}$ & $\begin{array}{l}\text { Accumulated } \\
\text { higher } \mathrm{H}_{2} \mathrm{O}_{2} \\
\text { content }\end{array}$ & [103] \\
\hline $\begin{array}{l}\text { Vigna radiate } \mathrm{L} . \mathrm{cv} \text {. } \\
\text { BINA moog-1 }\end{array}$ & $25 \%$ PEG & $\begin{array}{l}\text { Reduced AsA content along with } \\
\text { higher GSH content of } 92 \% ; \\
\text { Increased GSSG content by } 236 \% \\
\text { and reduced GSH/GSSG ratio; } \\
\text { Amplified the activity of APX (21\%) } \\
\text { and GR while reduced MDHAR } \\
\text { and DHAR activities }\end{array}$ & $\begin{array}{l}\text { Elevated } \mathrm{H}_{2} \mathrm{O}_{2} \\
\text { content by } 114 \% \\
\text { with higher } \mathrm{O}_{2}^{-} \\
\text {generation }\end{array}$ & [111] \\
\hline$V$. radiata $\mathrm{L}$. & $200 \mathrm{mM} \mathrm{NaCl}$ & $\begin{array}{l}\text { Reduced AsA content; Increased } \\
\text { GSSG and GSH accumulation and } \\
\text { lowered GSH/GSSG ratio; } \\
\text { Amplified the activity of APX, } \\
\text { MDHAR, DHAR, and GR }\end{array}$ & $\begin{array}{c}\text { Increased } \mathrm{H}_{2} \mathrm{O}_{2} \\
\text { content by } 80 \% \text { and } \\
\mathrm{O}_{2}^{-} \text {generation by } \\
86 \%\end{array}$ & [95] \\
\hline $\begin{array}{l}\text { V. radiata L. cv. } \\
\text { BARI Mung-2 }\end{array}$ & $5 \%$ PEG & $\begin{array}{l}\text { Reduced AsA content where } \\
\text { decreased AsA/DHA ratio by } 54 \% \text {; } \\
\text { Increased GSSG content; } \\
\text { Upregulated the activity of APX and } \\
\text { GR }(42 \%) \text { while downregulated the } \\
\text { MDHAR }(26 \%) \text { and DHAR activities }\end{array}$ & $\begin{array}{l}\text { Elevated } \mathrm{H}_{2} \mathrm{O}_{2} \text { and } \\
\mathrm{O}_{2}^{-} \text {accumulation }\end{array}$ & [50] \\
\hline $\begin{array}{l}\text { Lens culinaris } \\
\text { Medik cv. BARI } \\
\text { Lentil-7 }\end{array}$ & $20 \%$ PEG & $\begin{array}{l}\text { Lowered AsA content with higher } \\
\text { total GSH content; Unaltered the } \\
\text { APX and GR activities while the } \\
\text { increased activity of MDHAR and } \\
\text { DHAR }(64 \%)\end{array}$ & $\begin{array}{l}\text { Accumulated } \\
\text { higher } \mathrm{H}_{2} \mathrm{O}_{2} \\
\text { content }\end{array}$ & [96] \\
\hline $\begin{array}{l}\text { L. culinaris Medik } \\
\text { cv. BARI Lentil-7 }\end{array}$ & $100 \mathrm{mM} \mathrm{NaCl}$ & $\begin{array}{c}\text { Reduced AsA content by } 87 \% \text { while } \\
\text { increased total GSH content by } \\
260 \% \text {; Improved the activity of APX, } \\
\text { MDHAR, DHAR }(286 \%) \text { and GR } \\
(162 \%)\end{array}$ & $\begin{array}{l}\text { Increased } \mathrm{H}_{2} \mathrm{O}_{2} \\
\text { content by } 15 \%\end{array}$ & [96] \\
\hline $\begin{array}{l}\text { Anacardium } \\
\text { occidentale } \mathrm{L} \text {. }\end{array}$ & $\begin{array}{l}\text { 21-day water } \\
\text { withdrawal }\end{array}$ & $\begin{array}{l}\text { Enhanced total AsA and GSH } \\
\text { content; Increased APX activity }\end{array}$ & $\begin{array}{l}\text { Reduced } \mathrm{H}_{2} \mathrm{O}_{2} \\
\text { generation }\end{array}$ & [112] \\
\hline Arabidopsis & $\begin{array}{l}\text { 12-day water } \\
\text { withhold }\end{array}$ & $\begin{array}{l}\text { Showed higher GSH and GSSG } \\
\text { accumulation; Reduced GSH/GSSG } \\
\text { ratio; Increased GR activity }\end{array}$ & $\begin{array}{l}\text { Increased } \mathrm{H}_{2} \mathrm{O}_{2} \\
\text { accumulation rate }\end{array}$ & [108] \\
\hline Cajanus cajan L. & $\begin{array}{c}\text { Complete water } \\
\text { withholding for } 3,6 \\
\text { and } 9 \text { days }\end{array}$ & $\begin{array}{c}\text { Decreased GSH/GSSG ratio; } \\
\text { Increased the activity of APX, } \\
\text { DHAR, and GR }\end{array}$ & $\begin{array}{l}\text { Higher } \mathrm{H}_{2} \mathrm{O}_{2} \\
\text { content }\end{array}$ & [109] \\
\hline
\end{tabular}


Table 1. Cont.

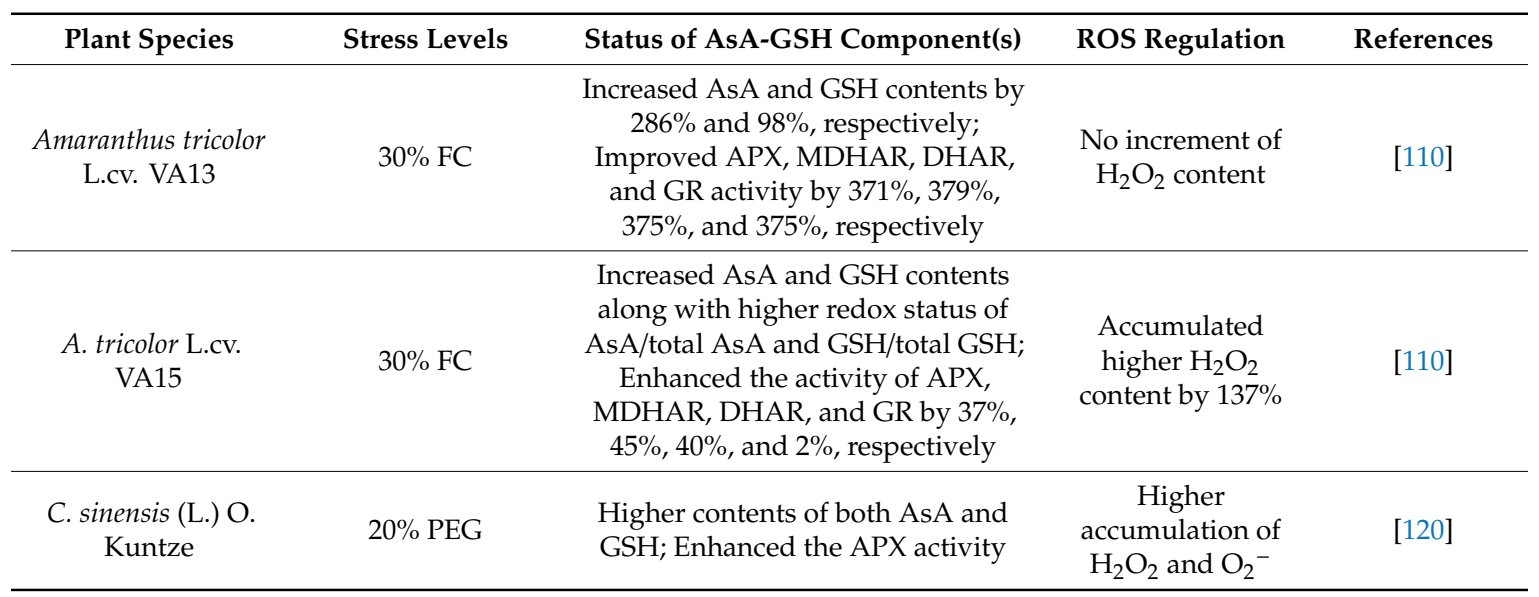

Drought-stressed A thaliana enhanced GSH and GSSG content along with the higher GR activity [108]. Hence, Arabidopsis showed the GSH dependent $\mathrm{H}_{2} \mathrm{O}_{2}$ detoxification to attain tolerance. Higher total AsA was accumulated in Cajanus cajan upon complete water restriction conditions for up to nine days to defend against excess $\mathrm{H}_{2} \mathrm{O}_{2}$ toxicity [109]. Hence, drought enhanced the enzymatic activity of APX, DHAR, and GR for decreasing GSH/GSSG, as well as controlling ROS level.

Similarly, tolerant genotype VA13 of Amaranthus tricolor showed comparatively better tolerance under drought stress than sensitive one (VA15) by expressing differential responses of the enzymatic and non-enzymatic ROS detoxification pathways [110]. Hence, VA13 expressed remarkable increment in AsA-GSH redox by accelerating the enzymatic antioxidative actions by which increased non-enzymatic antioxidants (AsA and GSH) accumulation, which are vital for ROS detoxification.

Vigna radiata responded differently regarding different drought intensity [111] to control diverse levels of ROS. Moderate drought imposed by $10 \%$ polyethylene glycol (PEG) induced comparatively lowered ROS than severe drought (by 20\% PEG). Therefore, severe drought-stressed Brassica showed a larger use of AsA-GSH pathways against higher $\mathrm{H}_{2} \mathrm{O}_{2}$ generation than moderate stress. Here, higher stress caused a higher increase of APX activity along with lowest MDHAR and DHAR activity, while GR activity reduced differently than lower stress exposure to rapeseeds seedlings. Additionally, Hasanuzzaman et al. [52] also observed AsA and GSH both antioxidants contents reduced under severe drought condition, but increased under moderate stress. Bhuiyan et al. [104] found increased AsA content in B. rapa under drought (20\% PEG). They also observed increased APX activity in drought-stressed seedlings, which assisted in efficiently scavenging the $\mathrm{H}_{2} \mathrm{O}_{2}$. Another two enzymes related to AsA regeneration MDHAR and DHAR also upregulated, as a result the AsA level was increased and strongly maintained its redox balance during oxidative stress situation. Nahar et al. [111] narrated the function of AsA as ROS detoxifier under drought stress where AsA content reduced in $V$. radiata with the increasing of ROS generation. Here, drought-induced higher APX activity enhanced the oxidation of AsA by scavenging $\mathrm{H}_{2} \mathrm{O}_{2}$ and improved GR activity increased the supply of GSH for involving ROS detoxification. Anacardium occidentale also showed the active participation of AsA-GSH cycle by integrative responses of both non-enzymatic and enzymatic antioxidants for drought-induced excess ROS regulation, where the higher accumulation of AsA and GSH, along with APX activity, coordinately reduced the overproduced $\mathrm{H}_{2} \mathrm{O}_{2}$ [112]. Thus, the AsA-GSH pathways involve in $\mathrm{ROS}$ detoxification as well as ROS homeostasis by eliminating excess ROS for keeping them up to the requirement of functioning cell signals.

\subsection{Toxic Metals/Metalloids}

Due to fast industrialization of the modern world and unrestrained anthropogenic activities, toxic metals/metalloids stresses have become a gargantuan problem for the plant growth and 
development [121]. Plants experience toxic metals/metalloids stress try to survive to some extent by using their well established antioxidant defense system. But, the activity and performance of defense system differ with stress concentration, stress duration, plant type, and age of the plant.

The enzymes of AsA-GSH pathway confirmed their differential responses to different toxic metals/metalloids stress (Table 2). Mahmud et al. [122] confirmed that due to $\mathrm{Cr}$ stress, the few components of AsA-GSH pathway increased their amount or activity in B. juncea L. cV. BARI Sharisha-11. They found five days duration of $0.15 \mathrm{mM}$ and $0.3 \mathrm{mM} \mathrm{K}{ }_{2} \mathrm{CrO}_{4}$ treatment decreased the content of AsA, but did not change the GSH content. Moreover, activities of APX and GR were enhanced; however, the activities of MDHAR and DHAR were diminished. The higher APX and GR activity might play a function in scavenging excess ROS. A similar upregulation of APX and GR was also recorded in B. napus L. cv. BINA sharisha 3 due to $\mathrm{Cd}$ treatment [123]. From two separate experiments, they also found $\mathrm{Cd}$ stress $(0.5 \mathrm{mM}$ and $1.0 \mathrm{mM} \mathrm{CdCl}$ ) for $48 \mathrm{~h}$ decreased the AsA content, but increased GSH content only under $0.5 \mathrm{mM} \mathrm{CdCl}_{2}$ treatment. Exposure of Gossypium to 50 and $100 \mu \mathrm{M} \mathrm{Pb}\left(\mathrm{NO}_{3}\right)_{2}$ for six weeks increased the $\mathrm{H}_{2} \mathrm{O}_{2}$ content and APX activity [124]. The addition of $150 \mu \mathrm{M} \mathrm{NiCl}_{2} \cdot 6 \mathrm{H}_{2} \mathrm{O}$ in growing media of $B$. juncea L. for one week increased the $\mathrm{H}_{2} \mathrm{O}_{2}$ content. Moreover, Ni stress decreased the AsA level but augmented the content of GSH and GSSG. Nickel also diminished the function of DHAR and MDHAR, however enhanced APX and GR activity [125]. Similar differential responses of AsA-GSH pathway components were also observed under As [126] and $\mathrm{Al}$ [50] toxicity. It can be stated that overproduced ROS plays the signaling role to some extent and inaugurate the higher activity of AsA-GSH enzymes under metals/metalloids toxicity. The upregulation of enzymes plays a significant role in maintaining the redox balance of AsA-GSH pathway under stress condition.

Table 2. Status of AsA-GSH in regulating oxidative stress under metal/metalloid stress.

\begin{tabular}{|c|c|c|c|c|}
\hline Plant Species & Stress Levels & Status of AsA-GSH Component(s) & ROS Regulation & References \\
\hline $\begin{array}{c}\text { Brassica napus L. cv. } \\
\text { BINA sharisha } 3\end{array}$ & 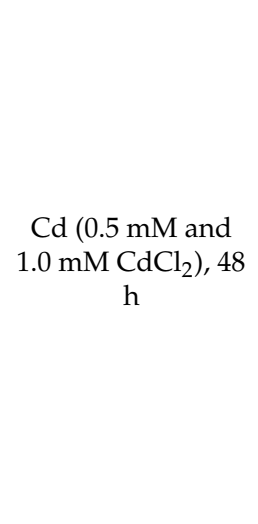 & $\begin{array}{l}\text { Reduced AsA content by } 20 \% \text { under } \\
0.5 \mathrm{mM} \text { and } 32 \% \text { under } 1.0 \mathrm{mM} \\
\mathrm{CdCl}_{2} \text { treatment; Increased } \mathrm{GSH} \\
\text { content only under } 0.5 \mathrm{mM} \mathrm{CdCl} 2 \\
\text { stress but enhanced level of } \mathrm{GSSG} \\
\text { by } 34 \% \text { under } 0.5 \mathrm{mM} \text { and } 65 \% \\
\text { under } 1.0 \mathrm{mM} \mathrm{CdCl} 2 \text { treatment; } \\
\text { Increased function of APX by } 39 \% \\
\text { and } 43 \% \text { under } 0.5 \mathrm{mM} \text { and } 1.0 \mathrm{mM} \\
\mathrm{CdCl}_{2} \text { treatment but } \mathrm{MDHAR} \text { and } \\
\text { DHAR activity were diminished in } \\
\text { dose dependant fashion; GR activity } \\
\text { increased by } 66 \% \text { due to } 0.5 \mathrm{mM} \\
\mathrm{CdCl}_{2} \text { treatment but reduced by } \\
24 \% \text { due to } 1.0 \mathrm{mM} \mathrm{CdCl} \text { treatment }\end{array}$ & $\begin{array}{l}\text { Enhanced } \mathrm{H}_{2} \mathrm{O}_{2} \\
\text { content by } 37 \% \\
\text { under } 0.5 \mathrm{mM} \text { and } \\
60 \% \text { under } 1.0 \mathrm{mM} \\
\mathrm{CdCl}_{2} \text { treatment }\end{array}$ & {$[88]$} \\
\hline $\begin{array}{c}\text { Gossypium spp. } \\
\text { (genotype } \mathrm{MNH} \\
886)\end{array}$ & $\begin{array}{l}\mathrm{Pb}[50 \text { and } 100 \mu \mathrm{M} \\
\left.\mathrm{Pb}\left(\mathrm{NO}_{3}\right)_{2}\right], 6 \text { weeks }\end{array}$ & Increased APX activity & $\begin{array}{c}\text { Increased } \mathrm{H}_{2} \mathrm{O}_{2} \\
\text { content }\end{array}$ & {$[124]$} \\
\hline $\begin{array}{l}\text { T. aestivum L. cv. } \\
\text { Pradip }\end{array}$ & $\begin{array}{c}\text { As }(0.25 \text { and } \\
0.5 \mathrm{mM} \\
\left.\mathrm{Na}_{2} \mathrm{HAsO}_{4} 7 \mathrm{H}_{2} \mathrm{O}\right) \\
72 \mathrm{~h}\end{array}$ & $\begin{array}{c}\text { Reduced AsA content by } 14 \% \text { under } \\
0.25 \text { and } 34 \% \text { underd } 0.5 \mathrm{mM} \\
\mathrm{Na}_{2} \mathrm{HAsO}_{4} \cdot 7 \mathrm{H}_{2} \mathrm{O} \text { treatment; } \\
\text { Increased } \mathrm{GSH} \text { content by } 46 \% \text { and } \\
34 \% \text {, GSSG content by } 50 \text { and } 101 \% \\
\text { under } 0.25 \text { and } 0.5 \mathrm{mM} \\
\mathrm{Na}_{2} \mathrm{HAsO}_{4} \cdot 7 \mathrm{H}_{2} \mathrm{O} \text { stress; Enhanced } \\
\mathrm{APX}_{\text {function by } 39 \% \text { and } 43 \% \text { but }} \\
\text { decreased } \mathrm{DHAR} \text { function by } 33 \% \\
\text { and } 30 \% \text { under } 0.25 \text { and } 0.5 \mathrm{mM} \\
\mathrm{Na}_{2} \mathrm{HAsO} \cdot 7 \mathrm{H} \mathrm{H}_{2} \mathrm{O} \text { treatment; } \\
\text { Increased GR function by } 31 \% \\
\text { under } 0.25 \text { mM }\end{array}$ & $\begin{array}{c}\text { Increased } \mathrm{H}_{2} \mathrm{O}_{2} \\
\text { content by } 41 \% \\
\text { under } 0.25 \text { and } 95 \% \\
\text { under } 0.5 \mathrm{mM} \\
\mathrm{Na}_{2} \mathrm{HAsO}_{4} \cdot 7 \mathrm{H}_{2} \mathrm{O} \\
\text { treatment }\end{array}$ & {$[127]$} \\
\hline
\end{tabular}


Table 2. Cont.

\begin{tabular}{|c|c|c|c|c|}
\hline Plant Species & Stress Levels & Status of AsA-GSH Component(s) & ROS Regulation & References \\
\hline $\begin{array}{l}\text { B. napus L. viz. ZS } \\
758, \text { Zheda619, ZY } \\
50 \text { and Zheda } 622\end{array}$ & $\begin{array}{l}\mathrm{Cr}(400 \mu \mathrm{M}) \\
15 \text { days }\end{array}$ & $\begin{array}{l}\text { Increased GSH and GSSG content; } \\
\text { Increased APX activity }\end{array}$ & $\begin{array}{l}\text { Increased } \mathrm{H}_{2} \mathrm{O}_{2} \\
\text { content }\end{array}$ & [128] \\
\hline $\begin{array}{l}\text { Oryza sativa } \mathrm{L} . \mathrm{cv} . \\
\text { BRRI dhan } 29\end{array}$ & $\begin{array}{c}\text { As }(0.5 \mathrm{mM} \text { and } \\
\left.1 \mathrm{mM} \mathrm{Na}_{2} \mathrm{HAsO}_{4}\right) \\
5 \text { days }\end{array}$ & $\begin{array}{l}\text { Decreased AsA content by } 33 \text { and } \\
51 \% \text { and increased DHA content by } \\
27 \% \text { and } 40 \% \text { under } 0.5 \mathrm{mM} \text { and } \\
1 \mathrm{mM} \mathrm{Na}_{2} \mathrm{HAsO}_{4} \text { treatment, } \\
\text { respectively; Decreased ratio of } \\
\text { AsA/DHA; Enhanced GSH content } \\
\text { by } 48 \text { and } 82 \% \text { under } 0.5 \mathrm{mM} \text { and } \\
1 \mathrm{mM} \mathrm{Na}_{2} \mathrm{HAsO}_{4} \text { treatment, } \\
\text { respectively; Enhanced GSSG } \\
\text { content whereas lessened } \\
\text { GSH/GSSG ratio by } 25 \% \text { under } \\
0.5 \mathrm{mM} \text { and } 41 \% \text { under } 1 \mathrm{mM} \\
\mathrm{Na}_{2} \mathrm{HAsO}_{4} \text { treatment; Augmented } \\
\text { the function of APX, MDHAR, and } \\
\text { GR, however, reduced the activity } \\
\text { of DHAR }\end{array}$ & $\begin{array}{c}\text { Increased } \mathrm{H}_{2} \mathrm{O}_{2} \\
\text { content by } 65 \% \text { and } \\
89 \% \text { under } 0.5 \mathrm{mM} \\
\text { and } 1 \mathrm{mM} \\
\mathrm{Na}_{2} \mathrm{HAsO}_{4} \\
\text { treatment, } \\
\text { respectively }\end{array}$ & [126] \\
\hline $\begin{array}{l}\text { O. sativa } \mathrm{L} . \mathrm{cv} \text {. } \\
\text { Disang (tolerant) }\end{array}$ & $100 \mu \mathrm{M} \mathrm{AlCl}, 48 \mathrm{~h}$ & $\begin{array}{l}\text { Increased AsA content in both roots } \\
\text { and shoots; Enhanced the GSH } \\
\text { content in shoots; Higher activities } \\
\text { of APX, MDHAR, DHAR, and GR, }\end{array}$ & $\begin{array}{l}\text { Elevated the } \\
\text { generation of } \mathrm{H}_{2} \mathrm{O}_{2} \\
\text { and } \mathrm{O}_{2}^{-}\end{array}$ & [129] \\
\hline $\begin{array}{l}\text { O. sativa L.cv. } \\
\text { Joymati (sensitive) }\end{array}$ & $100 \mu \mathrm{M} \mathrm{AlCl}, 48 \mathrm{~h}$ & $\begin{array}{l}\text { Higher accumulation of AsA in both } \\
\text { roots and shoots; Reduced the GSH } \\
\text { content in roots while shoots } \\
\text { content was unaltered; Increased } \\
\text { APX, MDHAR, DHAR activities; } \\
\text { Slightly increased GR activities }\end{array}$ & $\begin{array}{c}\text { Higher } \\
\text { accumulation of } \\
\mathrm{H}_{2} \mathrm{O}_{2} \text { and } \mathrm{O}_{2}^{-}\end{array}$ & [129] \\
\hline $\begin{array}{l}\text { V. radiata } \mathrm{L} . \mathrm{cv} \text {. } \\
\text { BARI Mung-2 }\end{array}$ & $\begin{array}{l}\mathrm{Cd}(\text { mild: } 1.0 \mathrm{mM} \\
\mathrm{CdCl} \text {, severer: } \\
\left.1.5 \mathrm{mM} \mathrm{CdCl}_{2}\right), 48 \\
\text { h }\end{array}$ & $\begin{array}{l}\text { Declined AsA content by } 31 \% \text { due } \\
\text { to mild and } 41 \% \text { due to severe } \\
\text { stress; Enhanced DHA level and } \\
\text { reduced AsA/DHA ratio; GSH } \\
\text { content did not change due to mild } \\
\text { stress but enhanced owing to stress } \\
\text { severity; GSSG level enhanced, and } \\
\text { GSH/GSSG ratio decreased in } \\
\text { dose-dependent manner; Increased } \\
\text { function of APX but lessened } \\
\text { MDHAR and DHAR function due } \\
\text { to both level of stress; GR activity } \\
\text { increased only due to severe stress }\end{array}$ & $\begin{array}{c}\mathrm{H}_{2} \mathrm{O}_{2} \text { level and } \\
\mathrm{O}_{2}^{-} \text {generation rate } \\
\text { was augmented by } \\
73 \% \text { and } 127 \% \text { due } \\
\text { to mild and } 69 \% \\
\text { and } 120 \% \text { due to } \\
\text { severe Cd stresses }\end{array}$ & [130] \\
\hline $\begin{array}{l}\text { V. radiata } \mathrm{L} . \mathrm{cv} \text {. } \\
\text { BARI Mung- } 2\end{array}$ & $\begin{array}{c}\mathrm{Cd}(1.5 \mathrm{mM} \mathrm{CdCl} \\
48 \mathrm{~h}\end{array}$ & $\begin{array}{l}\text { AsA content decreased by } 27 \% \text {, and } \\
\text { the ratio of AsA/DHA reduced by } \\
80 \% \text { whereas DHA content } \\
\text { increased considerably; Augmented } \\
\text { the function of APX and GR } \\
\text { however lessened function of } \\
\text { MDHAR and DHAR }\end{array}$ & $\begin{array}{c}\text { Increased } \mathrm{H}_{2} \mathrm{O}_{2} \\
\text { level and } \mathrm{O}_{2}^{-} \\
\text {generation rate }\end{array}$ & [131] \\
\hline $\begin{array}{l}\text { O. sativa L. cv. } \\
\text { BRRI dhan } 29\end{array}$ & $\begin{array}{l}\mathrm{Cd}(0.25 \mathrm{mM} \text { and } \\
\left.0.5 \mathrm{mM} \mathrm{CdCl}_{2}\right) \\
3 \text { days }\end{array}$ & $\begin{array}{l}\text { AsA content and AsA/DHA ratio } \\
\text { reduced by } 37 \% \text { and } 57 \% \text { due to } \\
0.25 \mathrm{mM} \mathrm{CdCl}_{2} \text { and reduced by } 51 \% \\
\text { and } 68 \% \text { due to } 0.5 \mathrm{mM} \mathrm{CdCl} \mathrm{m}_{2} \\
\text { respectively; DHA content } \\
\text { increased significantly; GSH content } \\
\text { enhanced due to } 0.25 \mathrm{mM} \mathrm{CdCl} 2 \\
\text { stress, but reduced due to } 0.5 \mathrm{mM} \\
\mathrm{CdCl}_{2} \text { stress; GSSG content } \\
\text { enhanced by } 76 \% \text { under } 0.25 \mathrm{mM} \\
\text { and } 108 \% \text { under } 0.5 \mathrm{mM} \mathrm{CdCl} 2 \\
\text { stress; Reduced ratio of GSH/GSSG } \\
\text { in dose dependant manner; } \\
\text { Enhanced APX, MDHAR and GR } \\
\text { activity }\end{array}$ & $\begin{array}{c}\text { Enhenced } \mathrm{H}_{2} \mathrm{O}_{2} \text { by } \\
46 \% \text { under } \\
0.25 \mathrm{mM} \mathrm{CdCl}_{2} \text { and } \\
84 \% \text { under } 0.5 \mathrm{mM} \\
\mathrm{CdCl}_{2} \text { treatmen } \\
\text { whereas } \mathrm{O}_{2}^{-} \\
\text {generation rate } \\
\text { increased in dose } \\
\text { dependant manner }\end{array}$ & [132] \\
\hline
\end{tabular}


Table 2. Cont.

\begin{tabular}{|c|c|c|c|c|}
\hline $\begin{array}{l}\text { O. sativa L. cv. } \\
\text { BRRI dhan } 29\end{array}$ & $\begin{array}{c}\mathrm{Cd}\left(0.3 \mathrm{mM} \mathrm{CdCl}_{2}\right) \\
3 \text { days }\end{array}$ & $\begin{array}{l}\text { Lessened level of AsA and } \\
\text { AsA/DHA ratio but enhanced DHA } \\
\text { level; Enhanced the level of GSH } \\
\text { and GSSG however lessened } \\
\text { GSH/GSSG ratio; Enhanced the } \\
\text { action of APX, MDHAR, and GR } \\
\text { whereas declined DHAR function }\end{array}$ & $\begin{array}{l}\text { Overproduced ROS } \\
\left(\mathrm{H}_{2} \mathrm{O}_{2} \text { and } \mathrm{O}_{2}^{-}\right)\end{array}$ & [133] \\
\hline $\begin{array}{c}\text { O. sativa L. } \\
\text { Zhunliangyou } 608\end{array}$ & $\begin{array}{c}\mathrm{Cd}(5 \mu \mathrm{M} \\
\left.\mathrm{Cd}\left(\mathrm{NO}_{3}\right)_{2} \cdot 4 \mathrm{H}_{2} \mathrm{O}\right) \\
6 \text { days }\end{array}$ & $\begin{array}{l}\text { Reduced AsA content; Increased } \\
\text { GSH content; Slightly reduced the } \\
\text { APX activity }\end{array}$ & $\begin{array}{c}\mathrm{H}_{2} \mathrm{O}_{2} \text { content } \\
\text { increased by } \\
22.73 \%\end{array}$ & [134] \\
\hline $\begin{array}{l}\text { Abelmoschus } \\
\text { esculentus L. } \\
\text { Moench }\end{array}$ & $\begin{array}{l}\mathrm{Pb}\left(100 \mathrm{mg} \mathrm{L}^{-1}\right) \\
21 \text { days }\end{array}$ & Increased AsA content & $\begin{array}{c}\text { Enhanced } \mathrm{H}_{2} \mathrm{O}_{2} \\
\text { content }\end{array}$ & [135] \\
\hline $\begin{array}{l}\text { B. juncea L. cv. } \\
\text { BARI Sharisha-11 }\end{array}$ & $\begin{array}{c}\mathrm{Cr} \text { (mild: } 0.15 \mathrm{mM} \\
\mathrm{K}_{2} \mathrm{CrO}_{4} \text {, severe: } \\
0.3 \mathrm{mM} \mathrm{K}_{2} \mathrm{CrO}_{4} \text { ) } \\
5 \text { days }\end{array}$ & $\begin{array}{l}\text { AsA content lessened by } 19 \% \text { due to } \\
\text { mild and } 32 \% \text { due to severe stress } \\
\text { whereas DHA level enhanced by } \\
83 \% \text { due to mild and } 133 \% \text { due to } \\
\text { severe stress as well as AsA/DHA } \\
\text { ratio lessened by } 47 \% \text { due to mild } \\
\text { and } 82 \% \text { due to severe stress; GSH } \\
\text { content did not change considerably } \\
\text { but GSSG content enhanced by } 42 \% \\
\text { due to mild and } 67 \% \text { due to severe } \\
\text { stress as well as GSH/GSSG ratio } \\
\text { lessened by } 26 \% \text { due to mild and } \\
41 \% \text { due to severe stress; The } \\
\text { function of APX enhanced by } 21 \% \\
\text { due to mild and } 28 \% \text { due to severe } \\
\text { stress; The activity of MDHAR and } \\
\text { DHAR reduced by } 25 \text { and } 32 \% \\
\text { under mild and } 31 \text { and } 50 \% \text {, under } \\
\text { severe stress, respectively; Mild } \\
\text { stress increased the activity of GR } \\
\text { by } 19 \% \text { while severe stress increased } \\
\text { by } 16 \%\end{array}$ & $\begin{array}{c}\mathrm{H}_{2} \mathrm{O}_{2} \text { level } \\
\text { enhanced by } 24 \% \\
\text { and } 46 \% \text { due to } \\
\text { mild and severe } \\
\text { stress. Similarly, } \\
\mathrm{O}_{2}^{-} \text {generation } \\
\text { rate also raised in a } \\
\text { dose-dependent } \\
\text { manner }\end{array}$ & [122] \\
\hline $\begin{array}{l}\text { B. campestris L. cv. } \\
\text { BARISharisha } 9, B \text {. } \\
\text { napus L. cv. BARI } \\
\text { Sharisha } 13 \text { and } B \text {. } \\
\text { juncea L. cv. BARI } \\
\text { Sharisha } 16\end{array}$ & $\begin{array}{c}\mathrm{Cd} \text { (mild: } 0.25 \mathrm{mM} \\
\mathrm{CdCl}_{2} \text {, severer: } \\
\left.0.5 \mathrm{mM} \mathrm{CdCl}_{2}\right) \\
3 \text { days }\end{array}$ & $\begin{array}{l}\text { Decreased level ofAsA, augmented } \\
\text { level of DHA as well as decreased } \\
\text { AsA/DHA ratio in all studied } \\
\text { cultivars; GSH and GSSG level } \\
\text { enhanced, but GSH/GSSG ratio } \\
\text { lessened in all studied cultivars; } \\
\text { APX and GR activities of all species } \\
\text { increased significantly under both } \\
\text { levels of Cd toxicity }\end{array}$ & $\begin{array}{l}\text { Enhanced } \mathrm{H}_{2} \mathrm{O}_{2} \\
\text { level and } \mathrm{O}_{2}^{-} \\
\text {production rate in } \\
\text { all tested cultivars } \\
\text { in a } \\
\text { concentration-dependent } \\
\quad \text { fashion }\end{array}$ & [136] \\
\hline $\begin{array}{l}\text { B. juncea L. BARI } \\
\text { Sharisha- } 11\end{array}$ & $\begin{array}{l}\text { Cd (mild: } 0.5 \mathrm{mM} \\
\text { CdCl} \text {, severer: } \\
\left.1.0 \mathrm{mM} \mathrm{CdCl}_{2}\right) \\
3 \text { days }\end{array}$ & $\begin{array}{l}\text { Reduced AsA content with higher } \\
\text { DHA content and thus decreased } \\
\text { AsA/DHA ratio; Increased GSH and } \\
\text { GSSG levels as well as declined } \\
\text { GSH/GSSG ratio; APX activity } \\
\text { increased where GR increased at } \\
\text { mild stress but remained unaltered } \\
\text { at severe stress; Decreased MDHAR } \\
\text { and DHAR activities }\end{array}$ & $\begin{array}{l}\text { Enhanced the } \\
\mathrm{H}_{2} \mathrm{O}_{2} \text { and } \mathrm{O}_{2}^{-} \text {level }\end{array}$ & [137] \\
\hline $\begin{array}{l}\text { V. radiata L. cv. } \\
\text { BARI Mung-2 }\end{array}$ & $\begin{array}{c}\mathrm{Al}\left(\mathrm{AlCl}_{3}, 0.5 \mathrm{mM}\right) \\
48 \text { and } 72 \mathrm{~h}\end{array}$ & $\begin{array}{l}\text { Enhanced DHA content but } \\
\text { reduced AsA level and AsA/DHA } \\
\text { ratio; Increased level of GSH and } \\
\text { GSSG but the diminished ratio of } \\
\text { GSH/GSSG; Augmented APX } \\
\text { activity but decreased MDHAR and } \\
\text { DHAR activity }\end{array}$ & $\begin{array}{c}\text { Enhanced } \mathrm{H}_{2} \mathrm{O}_{2} \\
\text { level by } 83 \% \text { and } \\
\mathrm{O}_{2}^{-} \text {generation } \\
\text { rate by } 110 \%\end{array}$ & [50] \\
\hline
\end{tabular}


Table 2. Cont.

\begin{tabular}{|c|c|c|c|c|}
\hline $\begin{array}{l}\text { T. aestivum L. cv. } \\
\text { Pradip }\end{array}$ & $\begin{array}{c}\mathrm{Pb} \text { [mild: } 0.5 \mathrm{mM} \\
\mathrm{Pb}\left(\mathrm{NO}_{3}\right)_{2} \text {, severer: } \\
\left.1.0 \mathrm{mM} \mathrm{Pb}\left(\mathrm{NO}_{3}\right)_{2}\right] \\
2 \text { days }\end{array}$ & $\begin{array}{l}\text { AsA decreased in a dose-dependent } \\
\text { manner; Mild stress improved the } \\
\text { GSH level, but severe stress reduced } \\
\text { it; Increased GSSG content; } \\
\text { Increased APX activity; Diminished } \\
\text { activity of MDHAR and DHAR in a } \\
\text { concentration-dependent fashion; } \\
\text { Mild stress improved GR activity } \\
\text { but severe stress reduced it }\end{array}$ & $\begin{array}{c}\text { Mild stress } \\
\text { increased } \mathrm{H}_{2} \mathrm{O}_{2} \\
\text { levels by } 41 \% \text {, but } \\
\text { severe stress } \\
\text { enhanced it by } 95 \% \\
\text { while } \mathrm{O}_{2}{ }^{-} \\
\text {generation rate also } \\
\text { increased in a } \\
\text { dose-dependent } \\
\text { manner }\end{array}$ & [35] \\
\hline $\begin{array}{l}\text { B. juncea L.cv. } \\
\text { BARI Sharisha-11 }\end{array}$ & $\begin{array}{c}\text { Cd (mild: } 0.5 \mathrm{mM} \\
\mathrm{CdCl} \text {, severer: } \\
\left.1.0 \mathrm{mM} \mathrm{CdCl}_{2}\right) \\
3 \text { days }\end{array}$ & $\begin{array}{l}\text { AsA content decreased by } 24 \% \text { due } \\
\text { to mild and } 42 \% \text { due to severe stress } \\
\text { whereas DHA level enhanced by } \\
79 \% \text { due mild and } 200 \% \text { due to } \\
\text { severe stress; Decreased AsA/DHA } \\
\text { ratio in dose-dependent manner; } \\
\text { GSH and GSSG content enhanced } \\
\text { by } 19 \% \text { and } 44 \% \text {, respectively, due } \\
\text { to mild stress, while only GSSG } \\
\text { content enhanced due to severe } \\
\text { stress by } 72 \% \text {; The ratio of } \\
\text { GSH/GSSG declined by } 17 \% \text { due to } \\
\text { mild and } 43 \% \text { due to severe stress; } \\
\text { Enhanced APX by } 15 \% \text { due to mild } \\
\text { and } 24 \% \text { due to severe stress; The } \\
\text { activity of MDHAR and DHAR } \\
\text { reduced by } 12 \% \text { and } 14 \% \text { due to } \\
\text { mild stress whereas } 17 \% \text { and } 24 \% \text {, } \\
\text { due to severe stress, respectively; } \\
\text { The activity of GR enhanced under } \\
\text { mild stress by } 16 \% \text { and lessened } \\
\text { under severe stress by } 9 \%\end{array}$ & $\begin{array}{c}\text { Level of } \mathrm{H}_{2} \mathrm{O}_{2} \\
\text { enhanced by } 43 \% \\
\text { due to mild and } \\
54 \% \text { due to severe } \\
\text { stress. Augmented } \\
\mathrm{O}_{2}^{-} \text {generation } \\
\text { rate in a } \\
\text { dose-dependent } \\
\text { manner }\end{array}$ & [138] \\
\hline $\begin{array}{l}\text { B. juncea L. cv. } \\
\text { varuna }\end{array}$ & $\begin{array}{c}\mathrm{Ni},(150 \mu \mathrm{M} \\
\left.\mathrm{NiCl}_{2 .} 6 \mathrm{H}_{2} \mathrm{O}\right) \\
1 \text { week }\end{array}$ & $\begin{array}{l}\text { AsA content decreased by } 61 \% \\
\text { whereas GSH and GSSG content } \\
\text { increased by } 75 \% \text { and } 151 \% \text {, } \\
\text { respectively; Enhanced function of } \\
\text { APX by } 60 \% \text { and GR by } 72 \% \text {; DHAR } \\
\text { and MDHAR activities were } \\
\text { decreased by } 62 \% \text { and } 65 \%, \\
\text { respectively }\end{array}$ & $\begin{array}{c}\text { Increased } \mathrm{H}_{2} \mathrm{O}_{2} \text { by } \\
\text { 3.23-fold }\end{array}$ & [125] \\
\hline $\begin{array}{l}\text { Pisum sativum L. cv. } \\
\text { Corne de Bélier }\end{array}$ & $\begin{array}{c}\mathrm{Pb}(500 \mathrm{mg} \mathrm{PbCl} 2 \\
\left.\mathrm{kg}^{-1}\right), 28 \text { days }\end{array}$ & Increased APX and GR activity & $\begin{array}{c}\text { Increased } \mathrm{H}_{2} \mathrm{O}_{2} \\
\text { content }\end{array}$ & [139] \\
\hline $\begin{array}{l}\text { O. sativa L. cv. } \\
\text { BRRI dhan54 }\end{array}$ & $\begin{array}{c}\mathrm{Ni}(0.25 \mathrm{mMand} \\
0.5 \mathrm{mM} \\
\left.\mathrm{NiSO}_{4} \cdot 7 \mathrm{H}_{2} \mathrm{O}\right)\end{array}$ & $\begin{array}{c}\text { Diminished content of AsA and } \\
\text { enhanced content of DHA as well as } \\
\text { the lessened ratio of AsA/DHA by } \\
73 \% \text { and } 92 \% \text { under } 0.25 \mathrm{mM} \text { and } \\
0.5 \mathrm{mM} \mathrm{NiSO} \cdot 7 \mathrm{H}_{2} \mathrm{O} \text { stress; GSH } \\
\text { and GSSG level enhanced in a } \\
\text { dose-dependent manner. However, } \\
\text { the GSH/GSSG ratio reduced only } \\
\text { under } 0.5 \mathrm{mM} \mathrm{NiSO} \cdot 7 \mathrm{H}_{2} \mathrm{O} \\
\text { treatment; } \mathrm{Increased} \mathrm{APX}, \mathrm{MDHAR} \\
\mathrm{DHAR} \text { and } \mathrm{GR} \text { activity by } 70 \%, 61 \% \text {, } \\
19 \% \text { and } 37 \% \text { under } 0.25 \mathrm{mM} \\
\mathrm{NiSO}_{4} \cdot 7 \mathrm{H}_{2} \mathrm{O} \text { and } 114 \%, 115 \%, 31 \% \\
\text { and } 104 \% \text { under } 0.5 \mathrm{mM} \\
\mathrm{NiSO}_{4} \cdot 7 \mathrm{H}_{2} \mathrm{O} \text { treatment, respectively }\end{array}$ & $\begin{array}{c}\text { Increased } \mathrm{H}_{2} \mathrm{O}_{2} \\
\text { content by } 28 \% \text { and } \\
35 \% \text { due to } \\
0.25 \mathrm{mM} \text { and } \\
0.5 \mathrm{mM} \\
\mathrm{NiSO}_{4} \cdot 7 \mathrm{H}_{2} \mathrm{O} \\
\text { treatment }\end{array}$ & [68] \\
\hline $\begin{array}{l}\text { Capsicum annuum } \\
\text { L.cv. Semerkand }\end{array}$ & $\begin{array}{c}\mathrm{Cd}(0.1 \mathrm{mM} \mathrm{CdCl}) \\
3 \text { weeks }\end{array}$ & Enhanced AsA and GSH content & $\begin{array}{c}\text { Increased } \mathrm{H}_{2} \mathrm{O}_{2} \\
\text { content }\end{array}$ & [140] \\
\hline $\begin{array}{l}\text { C. annuum L. cv. } \\
\text { Semerkand }\end{array}$ & $\begin{array}{c}\mathrm{Pb}(0.1 \mathrm{mM} \mathrm{PbCl})_{2} \\
3 \text { weeks }\end{array}$ & Enhanced AsA and GSH content & $\begin{array}{c}\text { Increased } \mathrm{H}_{2} \mathrm{O}_{2} \\
\text { content }\end{array}$ & [140] \\
\hline $\begin{array}{c}\text { Zea mays L. cv. Run } \\
\text { Nong } 35 \text { and Wan } \\
\text { Dan } 13\end{array}$ & $\begin{array}{c}\mathrm{Cd}(50 \mathrm{mg} \\
3 \mathrm{CdSO}_{4} \cdot 8 \mathrm{H}_{2} \mathrm{O} \mathrm{kg}^{-1} \\
\text { soil }), 6 \text { months }\end{array}$ & Decreased GSH content & $\begin{array}{c}\text { Increased } \\
\text { accumulation of } \\
\mathrm{H}_{2} \mathrm{O}_{2}\end{array}$ & [141] \\
\hline
\end{tabular}




\subsection{Extreme Temperature}

Along with the rise in average global temperature, HT stress has been turned into a topic to be concerned about among environmentalists and researchers worldwide. In general, a $5{ }^{\circ} \mathrm{C}$ temperature rise above the optimum temperature of growth is considered to be extreme temperature stress or HT stress or heat shock to any plant species [142,143]. Heat stress causes denaturation of protein and membrane lipids, enzyme inactivation, inhibited protein synthesis, and loss of membrane integrity [144], which results from the disruption of cellular homeostasis through the ROS formed in a mass amount under heat stress $[143,145]$. Focusing on the role of AsA-GSH pathway to scavenge these ROS, different crop species under different levels of extreme or HT stress have been studied (Table 3).

Khanna-Chopra and Chauhan [146] selected a warmer season to induce HT stress to two different cultivars of wheat (T. aestivum), which are Hindi62 (heat-tolerant) and PBW343 (heat-sensitive). They sowed the wheat seeds in mid-January and considered it as heat stress environment, while the control plants were sown in mid-November and considered as the non-stress environment. Data were collected at seven days interval up to 35 days after anthesis (DAA), and the results showed a sharp increase in $\mathrm{H}_{2} \mathrm{O}_{2}$ content up to 14 days, but then declined. Whereas, MDHAR and DHAR enzymes' activity only increased in Hindi62, but APX and GR activities showed a fluctuating pattern of alteration in both cultivars [146]. Another cereal Z. mays when experimented similarly with two different cultivars; LM-11 (heat-sensitive) and CML-32 (heat-tolerant), exposed to $40{ }^{\circ} \mathrm{C}$ for $72 \mathrm{~h}$, resulted in higher APX and GR activities in CML-32 roots, while a reduction occurred in the shoot. In LM-11, none of the enzyme activity or AsA content was affected [147]. Higher levels of $\mathrm{O}_{2}^{-}$production rate and $\mathrm{H}_{2} \mathrm{O}_{2}$ content were observed in Ficus concinna seedlings under $48 \mathrm{~h}$ of $\mathrm{HT}\left(35^{\circ} \mathrm{C}\right.$ and $\left.40^{\circ} \mathrm{C}\right)$ stress condition, where AsA and GSH contents were unaffected at $35^{\circ} \mathrm{C}$, while declining AsA at $40^{\circ} \mathrm{C}$ temperature [148]. The activity of APX, MDHAR, DHAR, and GR enzymes increased at $35^{\circ} \mathrm{C}$, but then again reduced at $40{ }^{\circ} \mathrm{C}$ to the level of control plants [148]. Under similar heat stress condition $\left(40^{\circ} \mathrm{C}, 48 \mathrm{~h}\right), \mathrm{V}$. radiata seedlings resulted in decreased GSH content and MDHAR-DHAR activities, but higher APX-GR activities [50]. Kiwi fruit (Actinidia deliciosa) seedlings, when exposed to $45^{\circ} \mathrm{C}$ in an incubator for $8 \mathrm{~h}$, resulted in higher AsA content and enhanced activity of all the AsA-GSH cycle enzymes [143]. Tomato seedlings were studied in two different aspects: short-term heat shock $\left(40^{\circ} \mathrm{C}, 9 \mathrm{~h}\right)$ [149] and long-term heat stress (38/28 ${ }^{\circ} \mathrm{C}$ day/night, seven days) [150]. In both experiments, the enhancement of $\mathrm{O}_{2}{ }^{-}$generation rate and $\mathrm{H}_{2} \mathrm{O}_{2}$ content were recorded, but enzyme (APX and GR) activity was only increased at short-term stress condition [149], while the long-term heat exposure reduced all four enzymes activities and GSH content [150]. Similar enzymatic activity was observed in Nicotiana tabacum seedlings after seven days of heat $\left(35^{\circ} \mathrm{C}\right)$ stress [151]. From the above discussion, it can be stated that heat stress prevailing for longer duration is less likely to have the capability to modulate AsA-GSH pathway as compared to short-term heat stress.

Table 3. Role of AsA-GSH in regulating oxidative stress under extreme temperature, flooding, and atmospheric pollutant.

\begin{tabular}{ccccc}
\hline Plant Species & Stress Levels & Status of AsA-GSH Component(s) & ROS Mitigation & References \\
\hline Actinidia deliciosa & $45^{\circ} \mathrm{C}, 8 \mathrm{~h}$ & $\begin{array}{c}\text { Increased content of AsA; Higher } \\
\text { activity of APX, MDHAR, DHAR, } \\
\text { and GR }\end{array}$ & $\begin{array}{c}\text { Increased } \mathrm{H}_{2} \mathrm{O}_{2} \\
\text { content }\end{array}$ & {$[143]$} \\
\hline $\begin{array}{c}\text { Zea mays L. cv. } \\
\text { Ludan No. } 8\end{array}$ & $46^{\circ} \mathrm{C}, 16 \mathrm{~h}$ & $\begin{array}{c}\text { Decreased GSH, and GSSG content, } \\
\text { but interestingly GSH/(GSH + GSSG) } \\
\text { ratio increased; Reduced GR activity }\end{array}$ & - & {$[154]$} \\
\hline $\begin{array}{c}\text { Cinnamonum } \\
\text { camphora }\end{array}$ & $40{ }^{\circ} \mathrm{C}, 2$ days & $\begin{array}{c}\text { Reduced AsA content with higher } \\
\text { DHA content; Increased GSH and } \\
\text { GSSG content; Enhanced the activities } \\
\text { of APX, MDHAr, DHAR, and GR }\end{array}$ & $\begin{array}{c}\mathrm{Higher}_{2} \text { content of } \\
\mathrm{H}_{2} \mathrm{O}_{2} \text { and } \mathrm{O}_{2}{ }^{-}\end{array}$ & {$[166]$} \\
\hline $\begin{array}{c}\text { S. lycopersicum L. cv. } \\
\text { Ailsa Craig }\end{array}$ & $40^{\circ} \mathrm{C}, 9 \mathrm{~h}$ & $\begin{array}{c}\text { Higher APX and GR activities by } 74 \% \\
\text { and 45\%, respectively }\end{array}$ & $\begin{array}{c}\mathrm{H}_{2} \mathrm{O}_{2} \text { content } \\
\text { increased by } 49 \%\end{array}$ & {$[149]$} \\
\hline
\end{tabular}


Table 3. Cont

\begin{tabular}{|c|c|c|c|c|}
\hline Plant Species & Stress Levels & Status of AsA-GSH Component(s) & ROS Mitigation & References \\
\hline $\begin{array}{c}\text { S. lycopersicum L.cv. } \\
\text { Boludo }\end{array}$ & $35^{\circ} \mathrm{C}, 30$ days & $\begin{array}{l}\text { Increased the APX, DHAR and GR } \\
\text { activities; Reduced the MDHAR } \\
\text { activity }\end{array}$ & $\begin{array}{l}\text { Increased } \mathrm{H}_{2} \mathrm{O}_{2} \\
\text { content }\end{array}$ & [119] \\
\hline Vicia faba L. cv. C5 & $42{ }^{\circ} \mathrm{C}, 48 \mathrm{~h}$ & $\begin{array}{l}\text { Enhanced the AsA, GSH ans GSSG } \\
\text { content significantly; The enzymatic } \\
\text { activity of APX and GR also enhanced }\end{array}$ & $\begin{array}{c}\text { Extreme } \\
\text { accumulation of } \\
\mathrm{O}_{2}^{-} \text {and } \mathrm{H}_{2} \mathrm{O}_{2}\end{array}$ & [167] \\
\hline $\begin{array}{l}\text { V.radiata L. cv. } \\
\text { BARI Mung-2 }\end{array}$ & $40^{\circ} \mathrm{C}, 48 \mathrm{~h}$ & $\begin{array}{c}\text { Decreased } 64 \% \text { in AsA/DHA ratio; } \\
\text { GSSG pool increased; Higher APX } \\
(42 \%) \text { and GR ( } 50 \%) \text { activities but } \\
\text { declined activities of MDHAR }(17 \%) \\
\text { and DHAR }\end{array}$ & $\begin{array}{c}\text { Higher } \mathrm{H}_{2} \mathrm{O}_{2} \\
\text { content and } \\
\mathrm{O}_{2}^{-} \text {- production rate }\end{array}$ & [50] \\
\hline $\begin{array}{l}\text { Z. mays cv. CML-32 } \\
\text { and LM-11 }\end{array}$ & $40^{\circ} \mathrm{C}, 72 \mathrm{~h}$ & $\begin{array}{l}\text { Increased AsA content in both shoot } \\
\text { and root of tolerant (CML-32) one, but } \\
\text { unaffected in the susceptible (LM-11) } \\
\text { one; Both APX and GR activity } \\
\text { increased in roots of CML-32 but } \\
\text { reduced in the shoot }\end{array}$ & $\begin{array}{c}\text { Higher } \mathrm{H}_{2} \mathrm{O}_{2} \\
\text { accumulation, } \\
\text { especially in shoots }\end{array}$ & [147] \\
\hline $\begin{array}{l}\text { L. esculentum Mill. } \\
\text { cv. Puhong } 968\end{array}$ & $\begin{array}{l}38 / 28^{\circ} \mathrm{C} \text { day/night, } \\
7 \text { days }\end{array}$ & $\begin{array}{c}\text { AsA+DHA and DHA increased by } \\
220 \% \text { and } 99 \% \text { respectively; } \\
\text { AsA/DHA ratio decreased by } 33 \% \text {; } \\
\text { Higher GSSG (25\%), but reduced GSH } \\
\text { content ( } 23.4 \% \text { ) and GSH/GSSG ratio } \\
(39 \%) ; \text { APX, MDHAR, DHAR and GR } \\
\text { activities declined }\end{array}$ & $\begin{array}{l}\text { Enhanced } \mathrm{O}_{2}^{-} \\
\text {generation rate and } \\
\mathrm{H}_{2} \mathrm{O}_{2} \text { content by } \\
129 \% \text { and } 33 \% \\
\text { respectively }\end{array}$ & [150] \\
\hline $\begin{array}{c}\text { Nicotiana tabacum } \\
\text { cv. BY-2 }\end{array}$ & $35^{\circ} \mathrm{C}, 7$ days & $\begin{array}{l}\text { Total GSH and AsA contents rose after } \\
7 \text { days heat stress; Increased MDHAR. } \\
\text { DHAR and GR activities up to } 72 \mathrm{~h}\end{array}$ & $\begin{array}{l}\text { The increasing } \\
\text { trend of } \mathrm{H}_{2} \mathrm{O}_{2} \\
\text { generation was } \\
\text { observed up to } 72 \\
\text { h, and then a sharp } \\
\text { decline occurred }\end{array}$ & [151] \\
\hline $\begin{array}{l}\text { Ficus concinna var. } \\
\text { subsessilis }\end{array}$ & $\begin{array}{c}35^{\circ} \mathrm{C} \text { and } 40^{\circ} \mathrm{C}, 48 \\
\mathrm{~h}\end{array}$ & $\begin{array}{l}\text { AsA content reduced at } 40{ }^{\circ} \mathrm{C} \text { but } \\
\text { GSH content similar to control at both } \\
35 \text { and } 40{ }^{\circ} \mathrm{C} \text {; DHA content enhanced } \\
\text { by } 49 \% \text { at } 35^{\circ} \mathrm{C} \text { and by } 70 \% \text { at } 40{ }^{\circ} \mathrm{C} \text {; } \\
\text { APX activity increased by } 51 \% \text { and } \\
30 \% \text { at } 35^{\circ} \mathrm{C} \text { and } 40{ }^{\circ} \mathrm{C} \text {; Activities of } \\
\text { MDHAR, DHAR, and GR increased at } \\
35^{\circ} \mathrm{C} \text {, but GR activity decreased by } \\
34 \% \text { at } 40^{\circ} \mathrm{C}\end{array}$ & $\begin{array}{c}\text { At } 35^{\circ} \mathrm{C}, 103 \% \\
\text { higher } \mathrm{H}_{2} \mathrm{O}_{2} \\
\text { content and } 58 \% \\
\text { higher } \\
\mathrm{O}_{2}{ }^{-} \text {production rate } \\
\text { and at } 40^{\circ} \mathrm{C} \text { those } \\
\text { were } 3.3 \text { - and } \\
2.2 \text {-fold } \\
\text { respectively }\end{array}$ & [148] \\
\hline $\begin{array}{l}\text { T. aestivum cv. } \\
\text { Hindi62 and } \\
\text { PBW343 }\end{array}$ & $\begin{array}{l}\text { Heat stress } \\
\text { environment, Late } \\
\text { sown } \\
\text { (Mid-January) }\end{array}$ & $\begin{array}{c}\text { Higher activities of MDHAR and } \\
\text { DHAR was observed in heat-tolerant } \\
\text { (Hindi62) one whereas other enzyme } \\
\text { activities seemed mostly to decline } \\
\text { with time }\end{array}$ & $\begin{array}{l}\text { The content of } \\
\mathrm{H}_{2} \mathrm{O}_{2} \text { was higher } \\
\text { up to } 14 \text { DAA } \\
\text { compared to } \\
\text { non-stressed } \\
\text { seedlings }\end{array}$ & [147] \\
\hline G. hirsutum cv. Siza & $\begin{array}{l}\text { Waterlogged pot } \\
\text { for } 3 \text { days and } \\
6 \text { days }\end{array}$ & $\begin{array}{c}\text { Increased content of AsA by } 20 \% \text { at } \\
3 \text { days and } 30 \% \text { at } 6 \text { days of } \\
\text { waterlogging; Lower APX, MDHAR } \\
\text { and GR activities }\end{array}$ & $\begin{array}{c}\text { Enhanced } \mathrm{O}_{2}^{-} \\
\text {generation rate by } \\
22 \text { and } 53 \% \text { and } \\
\mathrm{H}_{2} \mathrm{O}_{2} \text { content by } 10 \\
\text { and } 39 \% \text { at } 3 \text { and } \\
6 \text { days of } \\
\text { waterlogging, } \\
\text { respectively }\end{array}$ & [154] \\
\hline $\begin{array}{l}\text { Sesamum indicum L. } \\
\text { cv. BARI Til-4 }\end{array}$ & $\begin{array}{l}\text { Waterlogged pot by } \\
2 \mathrm{~cm} \text { standing } \\
\text { water on the soil } \\
\text { surface for } 2,4,6 \\
\text { and } 8 \text { days }\end{array}$ & $\begin{array}{l}\text { Reduced AsA content upto } 38 \% \text {; } \\
\text { Enhanced GSH and GSSG content } \\
\text { significantly; Increased APX and } \\
\text { MDHAR activities; Reduced DHAR } \\
\text { activity upto 59\%; GR activity } \\
\text { decreased upto } 23 \%\end{array}$ & $\begin{array}{l}\text { Increased } \\
\mathrm{H}_{2} \mathrm{O}_{2} \text { content } \\
\text { sharply }\end{array}$ & [168] \\
\hline $\begin{array}{l}\text { Z. mays cv. } \\
\text { Huzum- } 265 \text { and } \\
\text { Huzum-55 }\end{array}$ & $\begin{array}{l}\text { Root portions } \\
\text { waterlogged for } \\
21 \mathrm{~h}\end{array}$ & $\begin{array}{l}\text { Reduced AsA content in both } \\
\text { cultivars; Increased APX activity in } \\
\text { both cultivars }\end{array}$ & - & [159] \\
\hline
\end{tabular}


Table 3. Cont

\begin{tabular}{|c|c|c|c|c|}
\hline Plant Species & Stress Levels & Status of AsA-GSH Component(s) & ROS Mitigation & References \\
\hline Glycine $\max \mathrm{L}$. & $\begin{array}{l}\text { Waterlogged pot } \\
\text { for } 14 \text { days }\end{array}$ & $\begin{array}{l}\text { GSH activity declined sharply in roots } \\
\text { but shoots unaffected; Reduced GR } \\
\text { activity in shoots but roots unaffected }\end{array}$ & - & [153] \\
\hline $\begin{array}{l}\text { Trifolium repens L. } \\
\text { cv. Rivendel and } \\
\text { T. pratense L. cv. } \\
\text { Raya }\end{array}$ & $\begin{array}{l}2 \mathrm{~cm} \text { standing } \\
\text { water on the soil } \\
\text { surface for } 14 \text { days } \\
\text { and } 21 \text { days }\end{array}$ & $\begin{array}{l}\text { Increased contents of both oxidized } \\
\text { and reduced AsA observed in both } \\
\text { genotypes }\end{array}$ & $\begin{array}{l}\text { Higher } \mathrm{H}_{2} \mathrm{O}_{2} \\
\text { generation in both } \\
\text { genotypes }\end{array}$ & [158] \\
\hline $\begin{array}{l}\text { V. radiata L. cvs. } \\
\text { T- } 44 \text { and Pusa } \\
\text { Baisakhi; and } V \text {. } \\
\quad \text { luteola }\end{array}$ & $\begin{array}{l}\text { Pot filled with } \\
\text { water to } 1-2 \mathrm{~cm} \\
\text { height below the } \\
\text { soil level, } 8 \text { days }\end{array}$ & $\begin{array}{l}\text { Increased activities of both APX and } \\
\text { GR in tolerant genotypes but in } \\
\text { susceptible one, activities reduced }\end{array}$ & $\begin{array}{l}\text { Reduced contents } \\
\text { of } \mathrm{O}_{2}^{-} \text {and } \mathrm{H}_{2} \mathrm{O}_{2} \text { in } \\
\text { susceptible (Pusa } \\
\text { Baisakhi) cultivar }\end{array}$ & [156] \\
\hline $\begin{array}{l}\text { O. sativa L. } \\
\text { MR219-4, MR219-9 } \\
\text { and FR13A }\end{array}$ & $\begin{array}{l}\text { Complete } \\
\text { submergence for } 4, \\
8 \text { and } 12 \text { days }\end{array}$ & $\begin{array}{l}\text { APX activity declined by } 88 \% \text { in } \\
\text { FR13A under } 4 \text { days of submergence } \\
\text { but decreased about } 64 \text { and } 83 \% \\
\text { under } 8 \text { and } 12 \text { days of submergence; } \\
\text { GR activity increased in FR13A and } \\
\text { MR219- } 4 \text { cultivars by } 10 \text { - and } 13 \text {-fold } \\
\text { respectively after } 8 \text { days }\end{array}$ & - & [152] \\
\hline $\begin{array}{l}\text { Allium fistulosum L. } \\
\text { cv. Erhan }\end{array}$ & $\begin{array}{l}\text { Waterlogging ( } 5 \\
\mathrm{~cm}) \text { at substrate } \\
\text { surface for } 10 \text { days }\end{array}$ & Lower APX and GR activities & $\begin{array}{c}\text { Increased rate of } \\
\mathrm{O}_{2}^{-} \text {generation by } \\
240.4 \% \text { and } 289.8 \% \\
\text { higher } \mathrm{H}_{2} \mathrm{O}_{2} \\
\text { content }\end{array}$ & [157] \\
\hline $\begin{array}{l}\text { C. cajan } \mathrm{L} \text {. } \\
\text { genotypes ICPL } \\
84,023 \text { and ICP } \\
7035\end{array}$ & $\begin{array}{l}\text { Soil surface } \\
\text { waterlogged (1-2 } \\
\mathrm{cm}) \text { for } 6 \text { days }\end{array}$ & $\begin{array}{l}\text { Reduced APX and GR activities in } \\
\text { susceptible genotype, which was } \\
\text { higher in tolerant one }\end{array}$ & $\begin{array}{c}\text { Lower } \\
\text { accumulation of } \\
\mathrm{H}_{2} \mathrm{O}_{2} \text { and rate of } \\
\mathrm{O}_{2}^{-} \text {generation }\end{array}$ & [155] \\
\hline $\begin{array}{l}\text { S. melongena L. cv. } \\
\text { EG117 and EG203 }\end{array}$ & $\begin{array}{l}\text { Flooding with a } \\
\text { water level of } 5 \mathrm{~cm} \text {, } \\
72 \mathrm{~h}\end{array}$ & $\begin{array}{l}\text { Increased AsA content in susceptible } \\
\text { EG117 genotype GSH content in both } \\
\text { genotypes; Increased APX activity but } \\
\text { decreased GR activity }\end{array}$ & - & [169] \\
\hline $\begin{array}{l}\text { S. lycopersicum cv. } \\
\text { ASVEG and L4422 }\end{array}$ & $\begin{array}{l}\text { Flooding with a } \\
\text { water level of } 5 \mathrm{~cm} \text {, } \\
72 \mathrm{~h}\end{array}$ & $\begin{array}{c}\text { Increase in both AsA and GSH } \\
\text { contents; Non-significant changes in } \\
\text { APX and GR activities }\end{array}$ & - & [169] \\
\hline Lolium perenne & $\begin{array}{l}\text { Grown in an area } \\
\text { with high air } \\
\text { pollution }\end{array}$ & $\begin{array}{c}\text { APX and DHAR activities decreased } \\
\text { while MDHAR and GR activities } \\
\text { increased }\end{array}$ & $\begin{array}{c}\text { A higher } \\
\text { concentration of } \\
\mathrm{H}_{2} \mathrm{O}_{2} \text { in pollens }\end{array}$ & [162] \\
\hline $\begin{array}{l}\text { Populus deltoides } \times \\
\text { Populus nigra cvs. } \\
\text { Carpaccio and } \\
\text { Robusta }\end{array}$ & $\begin{array}{l}\mathrm{O}_{3} \text { treatment }(120 \\
\mathrm{nmol} \mathrm{mol}^{-1} \text { for } 13 \\
\mathrm{~h}), 17 \text { days }\end{array}$ & $\begin{array}{l}\text { No impact on AsA and GSH contents; } \\
\text { DHAR activity decreased while GR } \\
\text { and MDHAR activity increased }\end{array}$ & - & [164] \\
\hline Fragaria $\mathrm{x}$ anansa & $\begin{array}{l}\text { High dose of } \\
\text { carbon monoxide } \\
(\mathrm{CO}) \text { nitroxide } \\
\left(\mathrm{NO}_{x}\right) \text { and sulfur } \\
\text { dioxide }\left(\mathrm{SO}_{2}\right)\end{array}$ & $\begin{array}{l}\text { The activity of both APX and GR } \\
\text { increased upto medium dose but } \\
\text { reduced under high dose }\end{array}$ & $\begin{array}{l}\mathrm{H}_{2} \mathrm{O}_{2} \text { content as } \\
\text { well as } \mathrm{O}_{2}^{-} \\
\text {generation rate } \\
\text { increased }\end{array}$ & [165] \\
\hline $\begin{array}{l}\text { O. sativa L. cvs. } \\
\text { SY63 and WXJ14 }\end{array}$ & $\begin{array}{l}\text { Continuous } \mathrm{O}_{3} \\
\text { exposure for up to } \\
79 \text { days }\end{array}$ & $\begin{array}{l}\text { Both AsA and GSH contents are more } \\
\text { likely to decrease; APX, MDHAR, } \\
\text { DHAR, and GR activity increased up } \\
\text { to } 70 \text { days of } \mathrm{O}_{3} \text { exposure }\end{array}$ & $\begin{array}{l}\text { Both } \mathrm{O}_{2}^{-} \\
\text {generation rate and } \\
\mathrm{H}_{2} \mathrm{O}_{2} \text { contents } \\
\text { increased }\end{array}$ & [163] \\
\hline Prosopis juliflora & $\begin{array}{l}\text { Grown in the } \\
\text { polluted industrial } \\
\text { region }\end{array}$ & $\begin{array}{c}\text { The content of AsA and APX activity } \\
\text { increased under polluted } \\
\text { environment }\end{array}$ & - & [161] \\
\hline Erythrina orientalis & $\begin{array}{l}\text { Grown in a } \\
\text { polluted industrial } \\
\text { area }\end{array}$ & $\begin{array}{l}\text { Increased activities of both APX and } \\
\text { GR enzymes recorded }\end{array}$ & - & [160] \\
\hline $\begin{array}{l}\text { T. aestivum L. cv. } \\
\text { BARI Gom- } 26\end{array}$ & $\begin{array}{l}\text { Acidic } \mathrm{pH}(4.5) \text { of } \\
\text { growing media }\end{array}$ & $\begin{array}{l}\text { Increased AsA and GSH content; } \\
\text { Improved redox balance of } \\
\text { GSH/GSSG; Increased activity of APX, } \\
\text { MDHAR, DHR, and GR }\end{array}$ & $\begin{array}{c}\mathrm{H}_{2} \mathrm{O}_{2} \text { contents } \\
\text { increased by } 209 \%\end{array}$ & [170] \\
\hline
\end{tabular}




\subsection{Flooding}

Changes in global climate result in the frequent or unexpected occurrence of heavy rainfall in different regions of the globe, which causes a sudden flood and disrupts the normal ecosystem [2]. Such changes in the ecosystem may cause the extinction of plants species and imbalance in the natural environment [2]. Flooding induced production of ROS and subsequent cellular damage has been authenticated in many studies so far [152-154]. Following are the discussion regarding crop species facing flooding stresses and modulation of their AsA-GSH pathway by flooding stress (Table 3).

Pigeon pea (C. cajan) seedlings that are exposed to waterlogged condition for six days revealed that tolerant cultivar could increase APX and GR activities, but a susceptible one cannot [155]. They also observed that, unlike other cases, waterlogging caused a lower accumulation of $\mathrm{H}_{2} \mathrm{O}_{2}$ and $\mathrm{O}_{2}{ }^{-}$[155]. In another experiment with $V$. radiata, Sairam et al. [156] showed that waterlogging similarly reduced the $\mathrm{H}_{2} \mathrm{O}_{2}$ and $\mathrm{O}_{2}{ }^{-}$production rate in susceptible cultivar, while the tolerant ones remained unaffected. However, both APX and GR enzymes' activity increased in tolerant genotypes, while the susceptible one got reduced [156]. The enhanced production rate of $\mathrm{O}_{2}{ }^{-}$and $\mathrm{H}_{2} \mathrm{O}_{2}$ content under flooding stress have been reported in cotton [154], Welsh onion [157], and clover [158] plants. Cotton (G. hirsutum cv. Siza) plants after three and six days of flood exposure raised the AsA content, but reduced the activity of APX, MDHAR, and GR [154]. A similar reduction in APX and GR enzymes activities was also recorded in Welsh onion (Allium fistulosum L.) after 10 days of waterlogging stress [157]. When Z. mays seedlings were waterlogged for $21 \mathrm{~h}$ at their root portions, they resulted in reduced AsA content and increased APX activity [159]. On the other hand, under long duration (14 days) flooding stress, Glycine $\max$ L. plants showed a reduction of GSH activity in roots and GR activity in the shoot, but the GSH in shoot and GR in root were not affected [153]. In case of complete submergence of O. sativa L. plants for two, four, or eight days, elevated levels GR enzyme activity was recorded, while APX enzyme activity increased only in tolerant cultivar [152]. Accordingly, the discussion reveals that the impact of flooding stress on AsA-GSH pathway varies depending upon the plant species and duration.

\subsection{Atmospheric Pollutants}

Atmospheric pollutants are the substances that are assembled in the air to a level or magnitude that is dangerous for living beings. Plants that are grown under different levels of atmospheric pollution have shown their oxidative stress responses and AsA-GSH pathway regulation in different manners (Table 3).

Erythrina orientalis plants were grown in three different locations of Philippines: La Mesa (a non-polluted area); and, Makati and Quezon (highly air-polluted cities). The results revealed that plants grown in the non-polluted area had lower activities of APX and GR as compared to the ones grown in highly polluted areas [160]. A similar increase in APX activity along with higher AsA content was recorded in Prosopis juliflora plants grown under polluted industrial region [161]. In a recent experiment, Lucas et al. [162] studied Lolium perenne plants that were grown under two different areas of Spain, Madrid, and Ciudad Real, where Madrid was considered to be more polluted than Ciudad Real. The findings indicated that the pollens of L. perenne accumulated higher concentration of $\mathrm{H}_{2} \mathrm{O}_{2}$ and in shoots APX and DHAR activity declined, but the activity of MDHAR and GR increased in the shoot of L. perenne plants that were grown in Madrid [162]. When rice seedlings were exposed to continuous $\mathrm{O}_{3}$ treatment, the results showed a remarkable increase in both $\mathrm{O}_{2}{ }^{-}$generation rate and $\mathrm{H}_{2} \mathrm{O}_{2}$ content. In addition, contents of AsA and GSH reduced, while APX, MDHAR, DHAR, and GR activity increased upto 70 days of $\mathrm{O}_{3}$ exposure in SY63 cultivar and upto 79 days of $\mathrm{O}_{3}$ exposure in WXJ14 cultivar [163]. Ascorbate and GSH contents were not affected by $\mathrm{O}_{3}$ exposure in the Populus seedlings, but DHAR activity was lower, while the activity of GR and MDHAR was higher after 17 days of $\mathrm{O}_{3}$ treatment [164]. Young strawberry (Fragaria $\mathrm{x}$ anansa) seedlings were exposed to three different levels of $\mathrm{CO}, \mathrm{NO}_{\mathrm{x}}$, and $\mathrm{SO}_{2}$, which are as follows: $\mathrm{CO} @ 133,267$, and 533 ppm, $\mathrm{NO}_{\mathrm{x}}$ and $\mathrm{SO}_{2} @ 25,50$, and 199 ppm corresponding to low, medium, and high dose, respectively. As a result of exposure to these atmospheric pollutants, $\mathrm{H}_{2} \mathrm{O}_{2}$ content as well as $\mathrm{O}_{2}{ }^{-}$generation rate increased. 
However, at low and medium doses of their exposure APX and GR activity increased, while at a high dose that decreased [165]. All sorts of atmospheric pollutants have a remarkable effect on AsA-GSH pathway, but further studies are required to demonstrate that those pollutants completely induced the modification of the AsA-GSH pathway.

\subsection{Other Stress}

Conklin et al. confirmed the positive role of AsA in protecting plants from ultraviolet (UV) radiation [159], where they found that Vit-C deficient mutant of $A$. thaliana was suffered by stress-induced damages than that of wild type. AsA-deficient mutants also showed sensitivity to $\mathrm{O}_{3}$ stress due to a lower biosynthesis of AsA [171]. Gao and Zhang [172] reported that vitc1 mutants of A. thaliana showed physiological disorders and greater oxidative damages than the wild type, which was due to lower activities of antioxidant enzymes. Mutant plants also showed lower GSH/GSSG and higher $\mathrm{DHA} /(\mathrm{AsA}+\mathrm{DHA})$ ratio than the wild type. Singh et al. [173] observed a decrease in AsA-GSH cycle enzymes in UV-exposed plants, which in turn affected the plants with oxidative stress. Similar to higher plants, marine macroalga Ulva fasciata also showed a positive correlation between enhanced the functions of AsA-GSH cycle and better tolerance of plants to UV radiation [174]. In their study, scavenging of $\mathrm{H}_{2} \mathrm{O}_{2}$ was regulated by AsA-GSH cycle components, especially APX and GR. Noshi et al. [175] reported that AsA-GSH redox pool provided better protection of Arabidopsis from high-light mediated oxidative stress, which was mainly attained due to the higher activities of DHAR. However, both AsA and GSH were found to be responsible for conferring high light (HL) stress [175]. Later, Zheng et al. [176] that susceptibility of Arabidopsis mutant was to HL stress were related to the deficiency of AsA and GSH. When AsA deficient A. thaliana mutant (vtc2-1) exposed to HL, they generated a high level of $\mathrm{H}_{2} \mathrm{O}_{2}$ (an oxidative stress marker) than the wild type, which was highly and negatively correlated with the total AsA content. The lack of AsA also resulted in lower chlorophyll (chl) content, chl fluorescence parameters, and PSII photochemistry [176]. Recently, Choudhury et al. [177] studied the metabolomics of $A$. thaliana grown under HL and found that the increased biosynthesis of GSH supports the photochemistry that supports Arabidopsis better survival under HL stress.

The pivotal role of the AsA-GSH cycle was also observed in low pH stress also. Bhuyan et al. [170] tested five spring wheat cultivars at different levels of low $\mathrm{pH}$ stress. Their observation exhibited that low-pH stress resulted in elevated $\mathrm{O}_{2}{ }^{-}$and $\mathrm{H}_{2} \mathrm{O}_{2}$ generation. A decrease in AsA content with increased DHA content was observed, although the APX activity decreased. Increased MDHAR activity was observed, but the ratio of AsA/DHA was not increased. Decreased GSH content and increased GSSG content were found where DHAR and GR activity decreased, resulting in a drop of the GSH/GSSG ratio.

\section{Exogenous Use of AsA and GSH in Conferring Abiotic Stress Tolerance}

While considering the vital role of both AsA and GSH and their redox researches have been trying to explore the possibilities of using exogenous AsA and GSH in protective plants from abiotic stress. However, the effects are not straightforward due to their species and dose dependency. In the next sections, we provided a summary of the recent results on plant abiotic stress tolerance while applying exogenous AsA and GSH.

\subsection{Exogenous AsA}

As a non-enzymatic antioxidant, AsA is vital for plant defense mechanism by involving in stress perception and subsequent signaling, and therefore plant responses [178]. Besides its regenerative nature, AsA is also able to donate electrons with and/or without the help of enzymes, and thus significantly detoxifies ROS [179]. Thus, exogenous AsA application is the most prominent for enhancing plant tolerance due to its efficient protection against lipids and proteins oxidation under abiotic stresses [180].

Ascorbate can be exogenously applied as a foliage application, seed treatment, and co-treatment for the alleviation of stress-induced damages [181]. Many researchers reported about the supplemental 
AsA-mediated antioxidant defense regulation in various plant species under different stressors, such as salt stress [182], drought [183], extreme temperature [184], ozone [185], and heavy metal stress [186].

Supplemental AsA application effectively lowered the oxidative stress in salt-stressed Phaseolus vulgaris, as indicated by the reduction of malondialdehyde (MDA) and ROS accumulation through activating their immune systems related with up-regulation of SOD, CAT and GR activities [187]. The AsA recovered salinity-induced oxidative damage in Caralluma tuberculata by lowering the activity of APX, POD, CAT, and GR, which were increased upon saline toxicity [188]. Exogenous AsA-induced plant tolerance, especially on the AsA-GSH pathway, is cultivar dependent [189]. Hence, they used both salt-tolerant $O$. sativa cv. Pokkali and salt-sensitive O. sativa cv. Peta to exogenously apply AsA as co-treatment with salinity and found a reduction of $\mathrm{H}_{2} \mathrm{O}_{2}$ generation in both cultivars. Here, AsA enhanced endogenous AsA and GSH, along with higher SOD, APX, and GR activities in salt-stressed both cultivars in line with lowered ROS and MDA production. However, Pokkali showed more prominent responses of salt tolerance than Peta. Finally, Wang et al. [189] suggested that exogenous AsA differentially increased the salt tolerance mechanism, and thus lessened salt-induced ROS in two rice cultivars. Exogenous AsA enhanced the salinity tolerance of $Z$. mays through protecting oxidative stress with stimulation of plant antioxidant defense [190]. In this study, AsA was used as seed priming against $100 \mathrm{mM} \mathrm{NaCl}$, and AsA restored the salt-induced membrane damage. Hence, external AsA improved the non-enzymatic antioxidants, including Pro, AsA, and GSH accumulation, where SOD and GPX activities increased. Rady and Hemida [190] found lowered CAT activity in AsA treated seedlings under salt stress, which pointed out the AsA-induced decline of $\mathrm{H}_{2} \mathrm{O}_{2}$ generation.

Plants get relief from drought stress by exogenous AsA application, which was reported by previous researchers [114,191]. Alam et al. [114] studied the AsA induced attenuation of oxidative stress in B. napus, B. campestris, and B. juncea under 15\% PEG, indicated by decreasing lipoxygenase (LOX) activity, $\mathrm{H}_{2} \mathrm{O}_{2}$, and MDA contents. This AsA mediated oxidative stress mitigation was described by AsA caused the strengthening of plant antioxidant defense mechanisms. Hence, exogenous AsA not only responsible for modulating AsA-GSH cycle, but also increased other enzymatic antioxidants activities, such as CAT, GPX, Gly I, and Gly II in all plant species, except GST, which was only increased in B. napus. Exogenous AsA mitigated the PEG-induced oxidative stress in Z. mays where AsA used as co-treatment, later endogenous AsA content increased, followed by scavenging surplus $\mathrm{H}_{2} \mathrm{O}_{2}$ generation and a reduction of lipid peroxidation [191].The higher transcript levels of SOD, CAT, APX, GR, MDHAR, and DHAR were induced in tall fescue by AsA application under PEG-induced water crisis, in respect with the only stressed condition [192]. Subsequently, Xu et al. [192] recommended AsA as a phytoprotectant to improved plants tolerances upon drought stress.

Exogenously applied $50 \mu \mathrm{M}$ AsA decreased high temperature (HT, 45/35 $\left.{ }^{\circ} \mathrm{C}\right)$-induced elevated $\mathrm{H}_{2} \mathrm{O}_{2}$ and MDA contents with lowered electrolyte leakage (EL) in $V$. radiata [184]. Hence, supplemental AsA altered the heat-induced lowered SOD, CAT, APX, and GR activities with increasing endogenous AsA and GSH contents. The AsA also enhanced the antioxidant capacity of tomato to cope with low-temperature stress [193]. The foliar application of AsA decreased the EL and MDA content in T. aestivum seedlings when exposed to the combined stress of herbicide and low temperature $\left(-2{ }^{\circ} \mathrm{C}\right)$ [194]. This AsA-induced lowered oxidative damage might be because of ROS scavenging under stress indicated by AsA mediated lowered $\mathrm{O}_{2}{ }^{-}$and $\mathrm{H}_{2} \mathrm{O}_{2}$, which were attributed by increasing POD, APX, and GR activities.

Seed priming with AsA also increased plant tolerance to metal stress. Hence seed priming with AsA of $A$. esculentus showed the alleviation of $\mathrm{Pb}$-induced oxidative stress that was confirmed by lowered $\mathrm{H}_{2} \mathrm{O}_{2}$ and MDA contents [135]. This AsA-induced alleviation of oxidative stress supported by exogenous AsA mediated increment of endogenous AsA contents, as well as upregulation of SOD, POD, and CAT activities in Pb-stressed A. esculentus. The AsA priming also increased the anthocyanins content in $\mathrm{Pb}$-exposed seedlings, which again enhanced the metal tolerance by checking ROS production. Previously, exogenous foliar application of AsA on rice seedlings increased AsA, and 
GSH contents, while enhanced both AsA/DHA and GSH/GSSG redox status, along with higher APX and GR activities under Cd stress [195].

Alamri et al. [196] investigated the potentiality of exogenous AsA to remove the metal-induced oxidative stress in T. aestivum. They observed that AsA suppressed the higher content of MDA and $\mathrm{H}_{2} \mathrm{O}_{2}$ in $\mathrm{Pb}$ exposed seedlings by improving the antioxidant enzymes activities, including SOD, CAT, and GR. Thus, AsA-mediated higher activity of enzymatic antioxidants could be responsible for the lowered membrane damage indicated by $\mathrm{EL}$ as well as $\mathrm{Pb}$ tolerance.

The AsA supplementation also showed its effective role in the mitigation of $\mathrm{Cd}$-induced oxidative stress. Zhang et al. [141] reported that AsA application, as a foliar spray, could become a potent tool to alleviate $\mathrm{Cd}$ toxicity in Z. mays. They used $0.1,0.3$, and $0.5 \mathrm{mM}$ of AsA in against $3.36 \mathrm{mM} \mathrm{Cd}$ contamination, while they observed a remarkable gradual reduction of both $\mathrm{H}_{2} \mathrm{O}_{2}$ and MDA contents under stressed conditions with increasing AsA levels. Foliar AsA application improved endogenous GSH along with the augmentation of SOD, POD, CAT, and GR activities, which are in line with AsA-induced lessening of oxidative stress in Cd-exposed Z. mays.

Thus, exogenous AsA application scavenges ROS in the plant under abiotic stresses, and then protects cell membrane stability. Therefore, reduced MDA content and EL were reported with AsA application as a sign of AsA-induced alleviation of oxidative damages. Accordingly, such exogenous AsA-induced strengthening of plant antioxidant defense, along with lessening oxidative stress, explained the potential of AsA for conferring abiotic stresses.

\subsection{Exogenous GSH}

At endogenous level, being an active participant of AsA-GSH cycle, GSH scavenges $\mathrm{H}_{2} \mathrm{O}_{2}$ in enzyme-dependent pathways; GSH is a substrate for GPX; GSH detoxifies lipid hydroperoxides together with GSTs; and, GSH/GSSG induces signals for abiotic stress adaptation [6]. Moreover, several research studies reported that the exogenous application of GSH proved to confirm the additional beneficial effects for enhanced the antioxidant defense system and abiotic stress tolerance.

After exogenous GSH pretreatment, mung bean plants were imposed with $\mathrm{HT}\left(42{ }^{\circ} \mathrm{C}\right)$, and beneficial effects were noticed. It enhanced chl and leaf RWC; increased cellular GSH content and GSH/GSSG lowering GSSG content; amplified APX, MDHAR, DHAR, GR, GPX, GST, and CAT activities; exogenous GSH pretreatment upheld the activity of Gly I and Gly II of MG detoxification system. The upregulation of both antioxidant and glyoxalase system ensured the HT tolerance. Meanwhile, GSH supplementation with $\mathrm{HT}$ decreased $\mathrm{H}_{2} \mathrm{O}_{2}, \mathrm{O}_{2}{ }^{-}$, MDA level, the activity of LOX, and MG content [95]. Increased temperature $\left(35^{\circ} \mathrm{C}\right)$ in root-zone variably affected physiological processes, growth, and Calvin cycle, which mediated inconsistency in antioxidant components; HT also affected antioxidant enzymes' gene expression of Cucumis sativus L. seedlings. HT-induced reduction of GSH content, the ratio of GSH/GSSG, photosynthetic pigments level, photosynthesis, and changes of linked gene expression were evident. HT also augmented soluble protein, proline (Pro), $\mathrm{O}_{2}{ }^{-}$generation and MDA level, expression of genes, and antioxidant enzymes functioning. The application of supplemental GSH with HT upheld soluble protein, Pro, antioxidant enzymes activity, and its linked gene expression, as well as inhibited $\mathrm{O}_{2}{ }^{-}$generation and lipid peroxidation, than to HT treatment without GSH [197].

Exogenous GSH improved AsA, and GSH contents, GSH/GSSG, APX, MDHAR, DHAR, and GPX activity of antioxidant system in drought exaggerated mung bean seedlings, which helped to relieve the adverse effect reducing the ROS including $\mathrm{H}_{2} \mathrm{O}_{2}$ and $\mathrm{O}_{2}{ }^{-}$, both in content and visually in the leaf spots of which were visualized through histochemical detection. Exogenous GSH also decreased the LOX activity, which caused the oxidation of lipid. Exogenous GSH also up-regulated the activity of Gly I and Gly II, therefore, reduce the toxic consequence of MG, and MG-induced oxidative damage [111].

Exogenous GSH $(1.0 \mathrm{mM})$ positively regulated an antioxidant system in wheat plants facing lead $(\mathrm{Pb})$ stress. The imposition of $\mathrm{Pb}$ diminished growth, the relative water content of leaf, and $\mathrm{chl} a$ and $b$ content; amplified Pro level, $\mathrm{H}_{2} \mathrm{O}_{2}$, and $\mathrm{O}_{2}{ }^{-}$generation, and lipid peroxidation. Glutathione supplementation with $\mathrm{Pb}$ stress improved the AsA and GSH contents, GSH/GSSG, activities of MDHAR, 
DHAR, GR, SOD, CAT, and GPX, and decreased oxidative damage. The decline of $\mathrm{H}_{2} \mathrm{O}_{2}$ and $\mathrm{O}_{2}{ }^{-}$ generation and membrane lipid peroxidation was clear evidence, together with an increased level of Pro and chl, which contributed overall tolerance to Pb toxicity [35]. Pretreatment with $100 \mu \mathrm{M}$ GSH with $50 \mu \mathrm{M} \mathrm{Cd}$ reversed growth reduction and concealed Cd-provoked MDA buildup. In contrast to Cd compelled plants, GSH pretreatment reversed photosynthetic pigment destruction, downregulated $\mathrm{Cd}$ accumulation in root and shoot. Exogenous GSH considerably increased the functioning of POD and SOD. In contrast to the $\mathrm{Cd}$ affected plants, exogenous GSH pretreated plants extensively reassured decrease in $\mathrm{Cu}$ or augmented in Fe levels, which were due to Cd [198]. Exogenous GSH and Cys were applied on lead (100 and $500 \mathrm{mg} \mathrm{L}^{-1}$ ) affected Iris lactea var. chinensis, growth, accumulation of $\mathrm{Pb}$, and nonprotein thiol (NPT) accumulation pattern were observed. The addition of GSH improved GSH biosynthesis in root and shoot. Endogenous shoot level Cys was recorded for exogenous Cys addition. Exogenous GSH application, together with buthionine sulfoximine (BSO) addition, regulated enzymes involved in GSH biosynthesis. This GSH played an imperative function in $\mathrm{Pb}$ accumulation and adaptation to this stress [199]. Exogenous GSH application improved the germination and growth of Arabidopsis, tobacco, and pepper under mercury ( $\mathrm{Hg}$ ) stress. Exogenous GSH also conferred $\mathrm{Cd}, \mathrm{Cu}$, and $\mathrm{Zn}$ stress tolerance. Exogenous GSH downregulated $\mathrm{H}_{2} \mathrm{O}_{2}$ and $\mathrm{O}_{2}{ }^{-}$generation and MDA content, whereas upregulated chl level under $\mathrm{Hg}$. Outstandingly, exogenous GSH reduced $\mathrm{Hg}$ accumulation in Arabidopsis. GSH showed high binding empathy to $\mathrm{Hg}$, as compared to $\mathrm{Cd}, \mathrm{Cu}$, or $\mathrm{Zn}$ [200].

Salt-tolerant Pokkali and sensitive cultivar Peta of rice were scrutinized for the role of exogenous GSH on them. Exogenous GSH increased the activity of SOD, APX, and GR, the amount of AsA and GSH, and reversed chloroplasts' $\mathrm{H}_{2} \mathrm{O}_{2}$ and MDA accumulation in either cultivar affected by salinity $(200 \mathrm{mM} \mathrm{NaCl})$. However, tolerance was prominent in cv. Pokkali [163]. The supplementation of GSH inverted the pessimistic properties of salinity stressed $(\mathrm{NaCl} 100 \mathrm{mM})$ tomato plants improving the transcript levels and activities of enzymes that are linked to GSH biosynthesis and metabolism. The biosynthesis-related enzymes were gamma-glutamylcysteine synthetase ( $\gamma$-ECS), glutathione synthetase (GS), whereas, others were GST, GPX, and GR. Exogenous supplemental GSH helped to upregulate the activity of SOD, peroxidase (POD), CAT, APX, MDHAR, DHAR and GR, GSH level, and GSH/GSSG in salt-stressed plants [201]. Externally applied GSH lessened the oxidative damage in different soybean genotypes via reducing $\mathrm{H}_{2} \mathrm{O}_{2}$ and MDA level, which were produced due to salinity. Glutathione supplementation minimizing the oxidative damage further contributed in yield attributes, and yield performance, which was seeds plant ${ }^{-1}$ and pods plant ${ }^{-1}, 100$-seed weight and yield [202]. Defensive function of supplemental GSH (1 mM GSH) was examined for salt (200 mM $\mathrm{NaCl}$ ) stressed mung bean. Mung bean plants when imposed with exogenous $\mathrm{GSH}$ and $\mathrm{NaCl}$ elevated AsA and GSH levels, GSH/GSSG, enhanced APX, MDHAR, DHAR, GR, SOD, CAT, GPX, and GST activities were recoded. Exogenous supplemental GSH also augmented the activity of Gly I and Gly II under salinity. Enhanced antioxidant and glyoxalase system components that resulted from the effect of exogenous GSH application had several beneficial effects. MDA, $\mathrm{H}_{2} \mathrm{O}_{2}$, and $\mathrm{MG}, \mathrm{O}_{2}{ }^{-}$production turned down, and leaf RWC and chl level raise; all of which made mung bean seedlings capable to perform better under saline growing media [95]. Glutathione was exogenously applied on tomato plants affected by salinity. Additional of GSH decreased oxidative stress. The reason behind this was revealed as redistribution of light energy in PSII, higher cellular GSH, GSH/GSSH ratio and activities of SOD, CAT and APX, MDHAR, DHAR, GR, and GRx. Glutathione supplementation revolutionized growth inhibition, $\mathrm{Na}^{+}$and $\mathrm{Cl}^{-}$ions balance, and $\mathrm{Na}^{+} / \mathrm{K}^{+}$. Choloplast, as well as stomatal function related to photosynthetic performance, were documented to improve after the application of GSH with salinity [203].

\section{Interaction of Other Pathways with AsA-GSH Pathways in Regulating ROS Metabolism}

Beside oxidative stress mitigation, the AsA-GSH cycle also interacts other pathways to reduce ROS and oxidative stress. Therefore, in this section, we will discuss the potentiality of AsA-GSH 
pathway components and their interaction with other pathways to modulate the ROS metabolism in plants.

\subsection{Interaction of AsA-GSH Cycle with NO Metabolic Pathway}

Although AsA-GSH cycle protects cellular components from oxidative damage, its components, especially the proteins (APX, MDHAR, DHAR, and GR), are also vulnerable to the oxidative damage, which can modify their activity, hence breaking down the antioxidant defense. In plants, nitric oxide can be produced from several biochemical pathways, both oxidative and reductive [35]. In the GSH pool, the reduced form of GSH can interact with NO and produce GSNO, which is further catalyzed by the action of GSNO reductase (GSNOR) and release NO and GSSG, and maintains the equilibrium of NO and nitrosothiols, as well as balance the redox state in the cell [204]. Moreover, S-nitrosylation could modify protein interactions, thus tinkering the antioxidant response [205]. Reports suggest that all of the proteins of the AsA-GSH cycle are influenced through S-nitrosylation and/or nitration, which are accomplished from the interaction with NO. Among the AsA-GSH cycle, enzymes APX is the most studied, which is directly influenced by NO metabolism. For example, the inactivation of APX1 is caused due to the oxidation of Cys32 [205]. Contrary, nitrosylation of APX1 active-site Cys32 increases its activity and this post translation modification (PTM) is performed during salinity stress, which increases oxidative stress as well as S-nitrosothiols [206]. Among the other enzymes, MDHAR is negatively modulated by nitration, which cuses enzymatic inactivity by altering the position of the cofactor binding site [206], and hence disturb the AsA recycling process. Although information is available on the nitration and activity modulation of DHAR proteins $[207,208]$, but the involvement of Try in this process, as well as the structural alteration impact of the enzyme, is still unclear. Moreover, GR is also targeted for nitration, which is reported to inhibit its activity in a mammalian cell, but the chloroplasic and cytosolic GR of pea is not affected by nitration [206].

\subsection{Signaling Role of AsA-GSH Cycle Components and Interaction with Other Pathways}

Ascorbate serves as the co-factor for redox enzymes, as well as a precursor for several biosynthetic pathways. In addition, AsA is an important reducing agent for $\mathrm{Fe}, \mathrm{Cu}$, and $\mathrm{Mn}$, thus act as a pro-oxidant controlling toxic $\mathrm{OH}^{\bullet}$ production from the Haber-Weiss and Fenton reaction [209]. Besides, its role as an antioxidant is the most important part of detoxifying ROS. As a pro-oxidant AsA regenerate $\alpha$-tocopherol. Moreover, AsA also works in the photo-protection that is mediated by the xanthophylls cycle, where violaxanthin de-epoxidase use AsA as a co-factor [210]. Moreover, AsA is employed as the substrate for organic acid (oxalate and tartrate) biosynthesis (Figure 2). Rapid cell expansion is correlated with AO activity, which oxidized AsA [211]. During cell expansion, Pro residues present in the glycoproteins of cell wall undergo hydroxylation where prolyl hydroxylase use AsA as a cofactor [210]. Furthermore, AsA can potentially upregulate cytosolic free $\mathrm{Ca}^{2+}$ via anion channels and play a signaling role [212]. More than this breakdown of AsA to DHA by APX or AO creates an electrochemical gradient over the plasma membrane, which also has a signaling role.

Under abiotic stress conditions, GSH triggers adaptation or PCD by intercellular signaling [213]. Glutathionylation of protein Cys residues suggests its redox signaling role, which alters the transcription of proteins [214]. In Arabidopsis, stomatal movement induced from methyl jasmonate (MeJA) is regulated by intracellular GSH [215]. In tobacco, both GSH and GSSG application induce $\mathrm{Ca}^{2+}$ signaling as well

as the expression of a specific gene, which supports the involvement of GSH with signal pathways that connect the $\mathrm{Ca}^{2+}$-dependent protein kinase [216]. The protein family peroxiredoxins (Prxs) are also GSH dependent and catalyze the reduction of $\mathrm{H}_{2} \mathrm{O}_{2}$ [217]. The GSSG can be exchanged with sulfhydryl groups of proteins and produce protein-GSH disulfide conjugates, which has a long half-life and plays a vital role in cellular signaling [218]. Moreover, GSH influences translation, and PTM of proteins, modulation of metabolism, and gene expression [219]. Hence, the mechanistic process of GSH signaling role should be focused on in future studies. 


\subsection{AsA-GSH Cycle Interaction with Phytohormone Biosynthesis Pathways}

Ascorbate regulates phytohormone biosynthesis; hence, modulating plant development [220]. Ascorbate shows activity, where cell developments are affected by hormonal signaling and modulate effective signaling processes [221]. The abscisic acid (ABA) involvement in stagnating growth and metabolism suggests the crucial role of AsA sensing for plant survival [222]. In addition, a number of dioxygenases that are directly related to hormonal biosynthesis require AsA is a cofactor [223]. Moreover, a low AsA induces PR proteins, but do not alter antioxidative enzymes. Thus, AsA acts as a "crosstalking" signal, where ABA acts as an important intermediary signal induces PR1 proteins in many plants. Hence, phytohormone signaling arises the AsA-dependent PR genes regulation [224]. On the other hand, 1-aminocyclopropane-1-carboxylate (ACC) synthase (ACS) and ACC oxidase (ACO) genesencoding ethylene biosynthetic enzymes is induced by GSH. Further, GSH increases serine acetyl transferase (SAT) level and confers Ni toxicity tolerance [225]. In rice, the overexpression of SA metabolism genes gave raise to both SA and GSH content under oxidative stress [226]. Therefore, GSH triggers phytohormones, and vice versa, along with other signaling genes [227].

\subsection{Interaction of AsA-GSH Pathway with Glyoxalase Pathway}

There is an intimate relationship between AsA-GSH cycle and the glyoxalase pathway through GSH, where it plays a vital role in the detoxification of MG. Methylglyoxal is a respiratory byproduct and produced usually in plants and detoxifies by the glyoxalase system. However, MG is overproduced under stress, which causes toxicity [51]. Moreover, MG can disfunctionate antioxidant enzymes [1]. In the MG detoxification process, Gly I (EC 4.4.1.5) and Gly II (EC 3.1.2.6) work simultaneously to detoxify MG (Discussed in Section 6). In this pathway, Gly I uses GSH as a cofactor and conjugates MG with GSH to form S-D-lactoylglutathione (SLG), Gly II, and then produce D-lactate breaking SLG, and regenerate GSH (Figure 9) [1], thus playing important interaction with glyoxalase system.

\subsection{Interaction AsA-GSH Pathway with Xenobiotics Detoxification Pathways}

Xenobiotic detoxification involves the conjugation of toxic xenobiotics with GSH, which are further transferred to the vacuole by using ATP driven tonoplast transporter. This detoxification enables secondary metabolites biosynthesis as well as storing in the vacuole, such as anthocyanin. Plants are having GSH-dependent enzyme, GST, which detoxify herbicides by conjugating it with GSH. Therefore, the glutathionylated metabolites are imported to vacuolar by ABC (ATP-binding cassette) transporters. However, the GST mainly functions in catalyzing natural products that were observed with xenobiotics and, similar to those, catalyzes alternative GSH-dependent biotransformation reactions and binds and carries phytochemicals between cellular compartments [228].

\subsection{AsA-GSH Cycle Interaction with Metal Chelation Process}

Maintaining lower metal/metalloid(s) level inside the cell involves metal sequestration by low molecular weight thiols, for instance, metallothioneins (MTs) and phytochelatins (PCs). The two important enzymes involved in this process, glutaredoxin (GRx) and thioredoxin (TRx), are GSH dependent and neutralize $\mathrm{H}_{2} \mathrm{O}_{2}$ or controls of protein thiols [229]. On the other hand, PCs are another important chelating agent containing that thiol group that are upregulated by different metal/metalloid(s) [32]. The basic component for this PC is GSH. The biosynthesis of PCs is accomplished by the enzyme PC synthase (PCS), which requires GSH as a substrate. The enzyme is crucial for metal detoxification, metal homeostasis, and stress tolerance [137].

\section{Genetic Manipulation of AsA-GSH Pathway and Its Role in Abiotic Stress Tolerance}

The regulation of AsA and GSH pool plays an important role in mitigating oxidative stress in plants. To attain this, the regulation of the enzymes that are related to the AsA-GSH pathway is vital. There are many plant studies that considered the genetic manipulation of AsA-GSH pathway. These 
studied revealed that the overexpression of AsA-GSH pathway enzymes provided the plants better protection against oxidative stress under various environmental adversities (Table 4). Transgenic tobacco plants overexpressing PCAPX showed enhanced tolerance to salt and drought [230]. Transgenic plants exhibited a 347\% increase in APX activities under drought stress, as compared to control, which resulted in a remarkable decrease in $\mathrm{H}_{2} \mathrm{O}_{2}$ content $(136 \%)$ than that of wild type (309\%). The ascorbate content was also higher $63 \%$ ) when compared to wild type (42\%). Similar results were also observed in the case of salt stress [230]. Chin et al. [231] found that transgenic Arabidopsis overexpressing $O g C y t A P X 1$ scavenged ROS effectively and showed enhanced tolerance to salt and heat. The overexpression of Malpighia glabraMDHAR gene resulted in a higher biosynthesis of AsA, which provided tobacco plants tolerance to salt stress [232]. Shin et al. [233] observed that the coexpression of B. rapaBrMDHAR and BrDHAR genes provided a remarkable improvement of oxidative stress in A. thaliana. The overexpression of BrMDHAR and BrDHAR showed enhanced MDHAR and DHAR activities and higher AsA/DHA ration. These plants also provided better radical scavenging capacity, which resulted in lower $\mathrm{H}_{2} \mathrm{O}_{2}$ content. Yin et al. [234] found that Arabidopsis plants overexpressing the gene AtGR1 conferred Al stress tolerance by reducing reactive carnoyl species, which was mainly due to higher GSH level and GR activity. The plant that overexpressed AtGR1 also maintained the activity of $\mathrm{H}_{2} \mathrm{O}_{2}$-scavenging enzymes. For instance, GPX and APX activities in Al-treated plants were decreased by 21 and $46 \%$, respectively, but the wild-type plants only showed 8 and 30\% decreases in such activities [234].

Modulating several NAC genes [NAC domain consists of three different genes; NAM (no apical meristem)-ATAF (Arabidopsis transcription activation factor)-CUC (cup-shaped cotyledon)] are also an efficient way to transform the AsA-GSH cycle, consequently enhancing stress tolerance. The overexpression of wheat TaNAC2 in Arabidopsis lines showed tolerance against freezing, salt, and drought stress by modulating the AsA-GSH cycle [235]. Moreover, ectopic expression of SINAC2 conferred both salt (200 mM) and drought (20\% PEG) tolerance up to 10 days in transgenic Arabidopsis lines, which is correlated with the lower accumulation of ROS. In addition, the transcriptomic abundance GSH metabolizing genes was also observed in transgenic lines, leading to increased GSH synthesis and lesser oxidative damage [236].

Table 4. Overexpression of genes related to AsA-GSH pathway and their role in ROS scavenging.

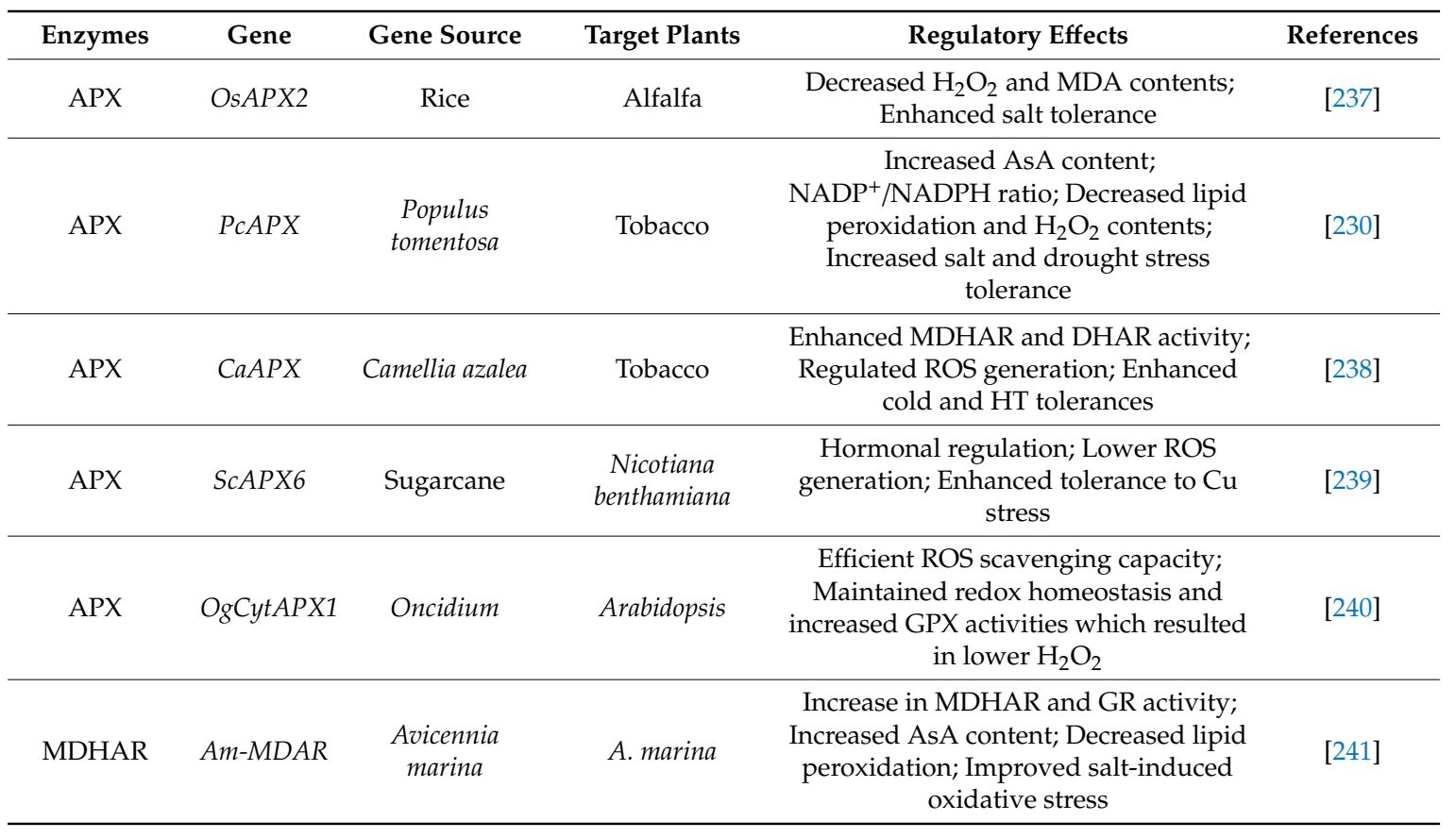


Table 4. Cont.

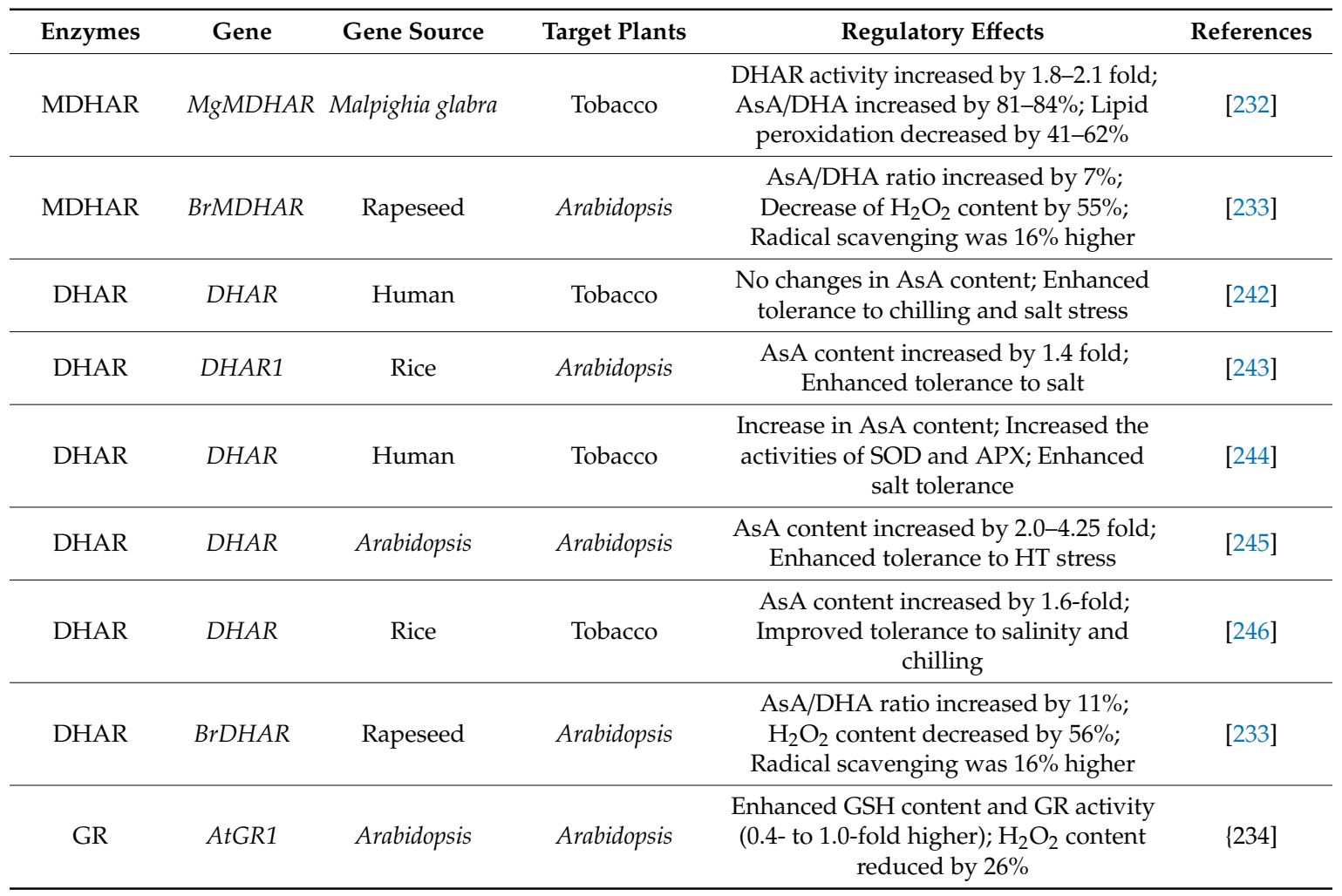

\section{Conclusions and Outlook}

Ascorbate and GSH have roles in decreasing oxidative stress, and it has been reported in numbers of research findings. Most of the research findings reported about their roles in antioxidant defense system for scavenging ROS. However, exogenous GSH related research on antioxidant defense system needs further confirmation at the genetic and molecular level. Moreover, without the commonly known ROS, like $\mathrm{H}_{2} \mathrm{O}_{2}, \mathrm{OH}, \mathrm{O}_{2}{ }^{-}$, etc. some other oxidative stress-inducing agents, like reactive nitrogen species, MG, etc., should be brought under consideration for research. How GSH can affect the generation of other kinds of oxidative stress-inducing damage. Research that is related to exogenous AsA or GSH-induced GST activity concerning xenobiotic detoxification is rare. The regulation of tocopherol by AsA or GSH can be an interesting area of research. For the reduction of metal-induced oxidative stress protection, GSH plays a vital role by producing PCs and inducing vacuolar sequestration. The credible function of AsA-GSH cycle in this area is so far to explicate. The GSH/GSSG redox is a well-reported term when discussing stress-induced oxidative damage and signal transduction process towards adaptation though the process is not well revealed. Interaction between and among the AsA-GSH cycle components and the hormones, other signaling molecules or any other molecules in oxidative stress, redox regulation, or plant adaptation process is not well understood. It is well known that chloroplast, its photosystem, and Calvin cycle activity or photosynthesis process is the maximum contributor of most of the ROS and oxidative stress under any abiotic stress condition. Several research findings reported about the role of AsA and GSH in improving the chl or carotenoid levels. However, very few of them reported regarding the roles of AsA and GSH in regulating stomatal conductance, Calvin cycle, RuBP activity/regeneration, or photosystem efficiency, which directly generates ROS and results in oxidative stress [203]. Some of the research findings show the positive roles of GSH improving/regulating Pro, which is cellular ROS scavenger or cytosol stabilizer to reduce ROS generation. These are the promising area of future research, which not only will alleviate the oxidative stress, but also improve the photosynthetic efficiency of plants for increasing plant production for the constantly growing population of the planet. 
Although, in this review article, we focused on abiotic stress-induced oxidative damage and the role of AsA-GSH cycle to mitigate such adversities, biotic stress (fungi, bacteria, virus, nematodes, and parasitic organisms, etc.) might also alter the essential plant processes as well as cellular metabolism.For example, the production of ROS and oxidative stress, disruption of membranes, hampering photosynthesis, changing enzyme activities, cell death, and yield loss might also be attributed to biotic stress, which is in line with abiotic stress.Biotic stress also disrupts signal transduction, as well as transfigures signal pathways that are associated with stress acclimation. Over the past decade, AsA-GSH cycle has also emerged as an important component for the plant biotic stress response. Similar to abiotic stresses, biotic stresses also alters the metabolism and changes in antioxidant activity. Therefore, AsA-GSH cycle also directly impacts the important metabolomic processes, thus providing an important link between metabolism, signal transduction, and acclimation to plants during biotic stress.

Author Contributions: M.H. constructed the main conceptual ideas and proof outline. All authors participated in the drafting of this paper as individual subject matter experts in their fields. M.H., M.H.M.B.B., and J.A.M. prepared the figures. M.H., T.I.A., K.P. and K.N. prepared the tables. M.H. and M.F. has contributed critically to the improvement and editing of the manuscript. All the authors contributed to collecting the literature, improving the paper, and approved the final manuscript.

Funding: This work received no external funding.

Acknowledgments: We thank Khadeja Sultana Sathi, Tonusree Saha, Mira Rahman and Naznin Ahmed for the formatting and proof checking of the manuscript.

Conflicts of Interest: The authors declare no conflict of interest.

\section{References}

1. Hasanuzzaman, M.; Nahar, K.; Anee, T.I.; Fujita, M. Glutathione in plants: Biosynthesis and physiological role in environmental stress tolerance. PMBP 2017, 23, 249-268. [CrossRef] [PubMed]

2. Hasanuzzaman, M.; Mahmud, J.A.; Nahar, K.; Anee, T.I.; Inafuku, M.; Oku, H.; Fujita, M. Responses, adaptation, and ROS metabolism in plants exposed to waterlogging stress. In Reactive Oxygen Species and Antioxidant Systems in Plants: Role and Regulation under Abiotic Stress; Khan, M.I.R., Khan, N.A., Eds.; Springer: New York, NY, USA, 2017.

3. Halliwell, B.; Gutteridge, J.M.C. Antioxidant defences: Endogenous and diet derived. Free Radic. Biol. Med. 2007, 4, 79-186.

4. Mittler, R. Oxidative stress, antioxidants and stress tolerance. Trends Plant Sci. 2002, 7, 405-410. [CrossRef]

5. Gill, S.S.; Tuteja, N. Reactive oxygen species and antioxidant machinery in abiotic stress tolerance in crop plants. Plant Physiol. Biochem. 2010, 48, 909-930. [CrossRef] [PubMed]

6. Hasanuzzaman, M.; Hossain, M.A.; Teixeira da Silva, J.A.; Fujita, M. Plant responses and tolerance to abiotic oxidative stress: Antioxidant defense is a key factor. In Crop Stress and its Management: Perspectives and Strategies; Bandi, V., Shanker, A.K., Shanker, C., Mandapaka, M., Eds.; Springer: Dordrecht, The Netherlands, 2012.

7. Sandalio, L.M.; Rodríguez-Serrano, M.; Romero-Puertas, M.C.; Luis, A. Role of peroxisomes as a source of reactive oxygen species (ROS) signaling molecules. In Peroxisomes and Their Key Role in Cellular Signaling and Metabolism; del Río, L., Ed.; Springer: Dordrecht, The Netherlands, 2013; pp. 231-255.

8. Hasanuzzaman, M.; Nahar, K.; Anee, T.I.; Fujita, M. Exogenous silicon attenuates cadmium-induced oxidative stress in Brassica napus L. by modulating AsA-GSH pathway and glyoxalase system. Front. Plant Sci. 2017, 8, 1061. [CrossRef] [PubMed]

9. Noctor, G.; Mhamdi, A.; Foyer, C.H. The roles of reactive oxygen metabolism in drought: Not so cut and dried. Plant Physiol. 2014, 164, 1636-1648. [CrossRef] [PubMed]

10. Hasanuzzaman, M.; Nahar, K.; Hossain, M.S.; Mahmud, J.A.; Rahman, A.; Inafuku, M.; Oku, H.; Fujita, M. Coordinated actions of glyoxalase and antioxidant defense systems in conferring abiotic stress tolerance in plants. Int. J. Mol. Sci. 2017, 18, 200. [CrossRef] 
11. Hasanuzzaman, M.; Nahar, K.; Hossain, M.S.; Anee, T.I.; Parvin, K.; Fujita, M. Nitric oxide pretreatment enhances antioxidant defense and glyoxalase systems to confer PEG-induced oxidative stress in rapeseed. J. Plant Interact. 2017, 12, 323-331. [CrossRef]

12. Zechmann, B. Compartment-specific importance of glutathione during abiotic and biotic stress. Front. Plant Sci. 2014, 5, 566. [CrossRef]

13. Szarka, A.; Tomasskovics, B.; Bánhegyi, G. The ascorbate-glutathione- $\alpha$-tocopherol triad in abiotic stress response. Int. J. Mol. Sci. 2012, 13, 4458-4483. [CrossRef]

14. Tripathi, R.P.; Singh, B.; Bisht, S.S.; Pandey, J. L-Ascorbic acid in organic synthesis: An overview. Curr. Org. Chem. 2009, 13, 99-122. [CrossRef]

15. Davey, M.W.; Montagu, M.V.; Inze, D.; Sanmartin, M.; Kanellis, A.; Smirnoff, N.; Benzie, I.J.J.; Strain, J.J.; Favell, D.; Fletcher, J. Plant L-ascorbic acid: Chemistry, function, metabolism, bioavailability and effects of processing. J. Sci. Food Agric. 2000, 80, 825-860. [CrossRef]

16. Mellidou, I.; Keulemans, J.; Kanellis, A.K.; Davey, M.W. Regulation of fruit ascorbic acid concentrations during ripening in high and low vitamin C tomato cultivars. BMC Plant Biol. 2012, 12, 239. [CrossRef] [PubMed]

17. Cronje, C.; George, G.M.; Fernie, A.R.; Bekker, J.; Kossmann, J.; Bauer, R. Manipulation of L-ascorbic acid biosynthesis pathways in Solanum lycopersicum: Elevated GDP-mannose pyrophosphorylase activity enhances L-ascorbate levels in red fruit. Planta 2012, 23, 553-564. [CrossRef] [PubMed]

18. Ishikawa, T.; Maruta, T.; Yoshimura, K.; Smirnoff, N. Biosynthesis and regulation of ascorbic acid in plants. In Antioxidants and Antioxidant Enzymes in Higher Plants; Gupta, D., Palma, J., Corpas, F., Eds.; Springer: Cham, Switzerland, 2018; pp. 163-179.

19. Wheeler, G.; Ishikawa, T.; Pornsaksit, V.; Smirnoff, N. Evolution of alternative biosynthetic pathways for vitamin $C$ following plastid acquisition in photosynthetic eukaryotes. Elife 2015, 4, e06369. [CrossRef] [PubMed]

20. Pallanca, J.E.; Smirnoff, N. The control of ascorbic acid synthesis and turnover in pea seedlings. J. Exp. Bot. 2000, 345, 669-674. [CrossRef]

21. Asada, K. Production and scavenging of reactive oxygen species in chloroplasts and their functions. Plant Physiol. 2006, 141, 391-396. [CrossRef]

22. Miyake, C. Alternative electron flows (water-water cycle and cyclic electron flow around PSI) in photosynthesis: Molecular mechanisms and physiological functions. Plant Cell Physiol. 2010, 51, 1951-1963. [CrossRef]

23. Loewus, F.A. Biosynthesis and metabolism of ascorbic acid and of analogs of ascorbic acid in fungi. Phytochemistry 1999, 52, 193-210. [CrossRef]

24. Melino, V.J.; Soole, K.L.; Ford, C.M. Ascorbate metabolism and the developmental demand for tartaric and oxalic acids in ripening grape berries. BMC Plant Biol. 2009, 9, 145. [CrossRef]

25. Truffault, V.; Fry, S.C.; Stevens, R.G.; Gautier, H. Ascorbate degradation in tomato leads to accumulation of oxalate, threonate and oxalyl threonate. Plant J. 2017, 89, 996-1008. [CrossRef] [PubMed]

26. Dewhirst, R.A.; Clarkson, G.J.J.; Rothwell, S.D.; Fry, S.C. Novel insights into ascorbate retention and degradation during the washing and post-harvest storage of spinach and other salad leaves. Food Chem. 2017, 233, 237-246. [CrossRef] [PubMed]

27. Kärkönen, A.; Dewhirst, R.A.; Mackay, C.L.; Fry, S.C. Metabolites of 2,3-diketogulonate delay peroxidase action and induce non-enzymic $\mathrm{H}_{2} \mathrm{O}_{2}$ generation: Potential roles in the plant cell wall. Arch. Biochem. Biophys. 2017, 620, 12-22. [CrossRef] [PubMed]

28. Hasanuzzaman, M.; Hossain, M.A.; Fujita, M. Nitric oxide modulates antioxidant defense and the methylglyoxal detoxification system and reduces salinity-induced damage of wheat seedlings. Plant Biotechnol. Rep. 2011, 5, 353-365. [CrossRef]

29. Gill, S.S.; Anjum, N.A.; Hasanuzzaman, M.; Gill, R.; Trived, D.K.; Ahmad, I.; Pereira, E.; Tuteja, N. Glutathione reductase and glutathione: A boon in disguise for plant abiotic stress defense operations. Plant Physiol. Biochem. 2013, 70, 204-212. [CrossRef] [PubMed]

30. Noctor, G.; Queval, G.; Mhamdi, A.; Chaouch, S.; Foyer, C.H. Glutathione. The Arabidopsis Book. Am. Soc. Plant Biol. 2011, 9, e0142.

31. Noctor, G.; Mhamdi, A.; Chaouch, S.; Han, Y.I.; Neukermans, J.; Marquez-Garcia, B.E.L.E.N.; Queval, G.; Foyer, C.H. Glutathione in plants: An integrated overview. Plant Cell Environ. 2012, 35, 454-484. [CrossRef] 
32. Nahar, K.; Hasanuzzaman, M.; Fujita, M. Physiological roles of glutathione in conferring abiotic stress tolerance to plants. In Abiotic Stress Response in Plants; Gill, S.S., Tuteja, N., Eds.; Wiley: Weinheim, Germany, 2016; pp. 151-179.

33. Zagorchev, L.; Seal, C.; Kranner, I.; Odjakova, M. A central role for thiols in plant tolerance to abiotic stress. Int. J. Mol. Sci. 2013, 14, 7405-7432. [CrossRef]

34. Mahmood, Q.; Ahmad, R.; Kwak, S.S.; Rashid, A.; Anjum, N.A. Ascorbate and glutathione: Protectors of plants in oxidative stress. In Ascorbate-Glutathione Pathway and Stress Tolerance in Plants; Mahmood, Q., Ahmad, R., Kwak, S.S., Rashid, A., Anjum, N.A., Eds.; Springer: Berlin, Germany, 2010; pp. 209-229.

35. Hasanuzzaman, M.; Nahar, K.; Rahman, A.; Mahmud, J.A.; Alharby, H.F.; Fujita, M. Exogenous glutathione attenuates lead-induced oxidative stress in wheat by improving antioxidant defense and physiological mechanisms. J. Plant Interact. 2018, 13, 203-212. [CrossRef]

36. Ferretti, M.; Destro, T.; Tosatto, S.C.E.; La Rocca, N.; Rascio, N.; Masi, A. Gamma-glutamyl transferase in the cell wall participates in extracellular glutathione salvage from the root apoplast. New Phytol. 2009, 181, 115-126. [CrossRef]

37. Ohkama-Ohtsu, N.; Sasaki-Sekimoto, Y.; Oikawam, A.; Jikumaru, Y.; Shinoda, S.; Inoue, E.; Kamide, Y.; Yokoyama, T.; Hirai, M.Y.; Shirasu, K.; et al. 12-oxo-phytodienoic acid-glutathione conjugate is transported into the vacuole in Arabidopsis. Plant Cell Physiol. 2011, 52, 205-209. [CrossRef] [PubMed]

38. Su, T.; Xu, J.; Li, Y.; Lei, L.; Zhao, L.; Yang, H.; Feng, J.; Liu, G.; Ren, D. Glutathione-indole-3-acetonitrile is required for camalexin biosynthesis in Arabidopsis thaliana. Plant Cell 2011, 23, 364-380. [CrossRef] [PubMed]

39. Yadav, P.; Yadav, T.; Kumar, S.; Rani, B.; Jain, V.; Malhotra, S.P. Partial purification and characterization of ascorbate peroxidase from ripening ber (Ziziphus mauritiana L) fruits. Afr. J. Biotechnol. 2014, 13, 3323-3331.

40. del Río, L.A.; López-Huertas, E. ROS generation in peroxisomes and its role in cell signaling. Plant Cell Physiol. 2016, 57, 1364-1376. [CrossRef] [PubMed]

41. Anjum, N.A.; Sharma, P.; Gill, S.S.; Hasanuzzaman, M.; Khan, E.A.; Kachhap, K.; Mohamed, A.A.; Thangavel, P.; Devi, G.D.; Vasudhevan, P.; et al. Catalase and ascorbate peroxidase-Representative $\mathrm{H}_{2} \mathrm{O}_{2}$-detoxifying heme enzymes in plants. Environ. Sci. Pollut. Res. 2016, 23, 19002-19029. [CrossRef]

42. Guo, K.; Tu, L.; Wang, P.; Du, X.; Ye, S.; Luo, M.; Zhang, X. Ascorbate alleviates Fe deficiency-induced stress in cotton (Gossypium hirsutum) by modulating ABA levels. Front. Plant Sci. 2017, 7, 1997. [CrossRef] [PubMed]

43. Lagoa, R.; Samhan-Arias, A.K.; Gutierrez-Merino, C. Correlation between the potency of flavonoids for cytochrome c reduction and inhibition of cardiolipin-induced peroxidase activity. Biofactors 2017, 43, 451-468. [CrossRef]

44. Ullah, S.; Kolo, Z.; Egbichi, I.; Keyster, M.; Ludidi, N. Nitric oxide influences glycine betaine content and ascorbate peroxidase activity in maize. S. Afr. J. Bot. 2016, 105, 218-225. [CrossRef]

45. Leterrier, M.; Cagnac, O. Function of the various MDAR isoforms in higher plants. In Antioxidants and Antioxidant Enzymes in Higher Plants; Gupta, D., Palma, J., Corpas, F., Eds.; Springer: Cham, Switzerland, 2018; pp. 83-94.

46. Begara-Morales, J.C.; Chaki, M.; Valderrama, R.; Mata-Pérez, C.; Padilla, M.; Barroso, J.B. Transcriptional regulation of gene expression related to hydrogen peroxide $\left(\mathrm{H}_{2} \mathrm{O}_{2}\right)$ and nitric oxide (NO). In Nitric Oxide and Hydrogen Peroxide Signaling in Higher Plants; Gupta, D., Palma, J., Corpas, F.J., Eds.; Springer: Cham, Switzerland, 2019; pp. 69-90.

47. Park, A.K.; Kim, I.S.; Do, H.; Jeon, B.W.; Lee, C.W.; Roh, S.J.; Shin, S.C.; Park, H.; Kim, Y.S.; Kim, Y.H.; et al. Structure and catalytic mechanism of monodehydroascorbate reductase, MDHAR, from Oryza sativa L. japonica. Sci. Rep. 2016, 6, 33903. [CrossRef]

48. Sano, S. Molecular and functional characterization of monodehydro-ascorbate and dehydroascorbate reductases. In Ascorbic Acid in Plant Growth, Development and Stress Tolerance; Hossain, M., Munné-Bosch, S., Burritt, D., Diaz-Vivancos, P., Fujita, M., Lorence, A., Eds.; Springer: Cham, Switzerland, 2017; pp. 129-156.

49. Johnston, E.J.; Rylott, E.L.; Beynon, E.; Lorenz, A.; Chechik, V.; Bruce, N.C. Monodehydroascorbate reductase mediates TNT toxicity in plants. Science 2015, 349, 1072-1075. [CrossRef]

50. Nahar, K.; Hasanuzzaman, M.; Alam, M.; Rahman, A.; Mahmud, J.-A.; Suzuki, T.; Fujita, M. Insights into spermine-induced combined high temperature and drought tolerance in mung bean: Osmoregulation and roles of antioxidant and glyoxalase system. Protoplasma 2017, 254, 445-460. [CrossRef] [PubMed] 
51. Bhuyan, M.H.M.B.; Hasanuzzaman, M.; Mahmud, J.A.; Hossain, M.S.; Bhuiyan, T.F.; Fijuta, F. Unraveling morphophysiological and biochemical responses of Triticum aestivum L. to extreme $\mathrm{pH}$ : Coordinated actions of antioxidant defense and glyoxalase systems. Plants 2019, 8, 24. [CrossRef] [PubMed]

52. Hasanuzzaman, M.; Nahar, K.; Anee, T.I.; Khan, M.I.R.; Fujita, M. Silicon-mediated regulation of antioxidant defense and glyoxalase systems confers drought stress tolerance in Brassica napus L. S. Afr. J. Bot. 2018, 115, 50-57. [CrossRef]

53. Foyer, C.H.; Shigeoka, S. Understanding oxidative stress and antioxidant functions to enhance photosynthesis. Plant Physiol. 2011, 155, 93-100. [CrossRef] [PubMed]

54. Palma, F.; Carvajal, F.; Jamilena, M.; Garrido, D. Putrescine treatment increases the antioxidant response and carbohydrate content in zucchini fruit stored at low temperature. Postharvest Biol. Technol. 2016, 118, 68-70. [CrossRef]

55. Krishna Das, B.; Kumar, A.; Maindola, P.; Mahanty, S.; Jain, S.K.; Reddy, M.K.; Arockiasamy, A. Non-native ligands define the active site of Pennisetum glaucum (L.) R. Br dehydroascorbate reductase. Biochem. Biophys. Res. Commun. 2016, 473, 1152-1157. [CrossRef] [PubMed]

56. Noshi, M.; Yamada, H.; Hatanaka, R.; Tanabe, N.; Tamoi, M.; Shigeoka, S. Arabidopsis dehydroascorbate reductase 1 and 2 modulate redox states of ascorbate-glutathione cycle in the cytosol in response to photooxidative stress. Biosci. Biotechnol. Biochem. 2017, 81, 523-533. [CrossRef]

57. Do, H.; Kim, I.S.; Jeon, B.W.; Lee, C.W.; Park, A.K.; Wi, A.R.; Shin, S.C.; Park, H.; Kim, Y.S.; Yoon, H.S.; et al. Structural understanding of the recycling of oxidized ascorbate by dehydroascorbate reductase (OsDHAR) from Oryza sativa L. japonica. Sci. Rep. 2016, 6, 19498. [CrossRef]

58. Kataya, A.R.; Reumann, S. Arabidopsis glutathione reductase 1 is dually targeted to peroxisomes and the cytosol. Plant Signal. Behav. 2010, 5, 171-175. [CrossRef]

59. Yousuf, P.Y.; Hakeem, K.U.R.; Chandna, R.; Ahmad, P. Role of glutathione reductase in plant abiotic stress. In Abiotic Stress Responses in Plants; Ahmad, P., Prasad, M.N.V., Eds.; Springer: New York, NY, USA, 2012; pp. 149-158.

60. Hanukoglu, I. Conservation of the enzyme-coenzyme interfaces in FAD and NADP binding adrenodoxin reductase-A ubiquitous enzyme. J. Mol. Evol. 2017, 85, 205-218. [CrossRef]

61. Tang, X.; Webb, M.A. Soybean root nodule cDNA encoding glutathione reductase. Plant Physiol. 1994, 104, 1081-1082. [CrossRef] [PubMed]

62. Pang, C.H.; Wang, B.S. Role of ascorbate peroxidase and glutathione reductase in ascorbate-glutathione cycle and stress tolerance in plants. In Ascorbate-Glutathione Pathway and Stress Tolerance in Plants; Anjum, N., Chan, M.T., Umar, S., Eds.; Springer: Dordrecht, The Netherlands, 2010; pp. 91-113.

63. Couto, N.; Wood, J.; Barber, J. The role of glutathione reductase and related enzymes on cellular redox homoeostasis network. Free Radic. Biol. Med. 2016, 95, 27-42. [CrossRef] [PubMed]

64. Foyer, C.H.; Pellny, T.K.; Locato, V.; Hull, J.; De Gara, L. Analysis of redox relationships in the plant cell cycle: Determination of ascorbate, glutathione, and poly (ADPribose) polymerase (PARP) in plant cell cultures. In Redox-Mediated Signal Transduction, Methods in Molecular Biology; Hancock, J., Conway, M., Eds.; Springer: New York, NY, USA, 2019; pp. 165-181.

65. Zhu, S.; He, L.; Zhang, F.; Li, M.; Jiao, S.; Li, Y.; Chen, M.; Zhao, X.E.; Wang, H. Fluorimetric evaluation of glutathione reductase activity and its inhibitors using carbon quantum dots. Talanta 2016, 161, 769-774. [CrossRef] [PubMed]

66. Hasanuzzaman, M.; Oku, H.; Nahar, K.; Bhuyan, M.B.; Mahmud, J.A.; Baluska, F.; Fujita, M. Nitric oxide-induced salt stress tolerance in plants: ROS metabolism, signaling, and molecular interactions. Plant Biotechnol. Rep. 2018, 12, 77-92. [CrossRef]

67. Nahar, K.; Hasanuzzaman, M.; Suzuki, T.; Fujita, M. Polyamines-induced aluminum tolerance in mung bean: A study on antioxidant defense and methylglyoxal detoxification systems. Ecotoxicology 2017, 26, 58-73. [CrossRef] [PubMed]

68. Hasanuzzaman, M.; Alam, M.M.; Nahar, K.; Mohsin, S.M.; Bhuyan, M.H.M.B.; Parvin, K.; Fujita, M. Silicon-induced antioxidant defense and methylglyoxal detoxification works coordinately in alleviating nickel toxicity in Oryza sativa L. Ecotoxicology 2019, 28, 261-276. [CrossRef] [PubMed]

69. Anjum, N.A.; Khan, N.A.; Sofo, A.; Baier, M.; Kizek, R. Redox homeostasis managers in plants under environmental stresses. Front. Environ. Sci. 2016, 4, 35. [CrossRef] 
70. Smirnoff, N. Ascorbic acid: Metabolism and functions of a multi-facetted molecule. Curr. Opin. Plant Biol. 2000, 3, 229-235. [CrossRef]

71. Foyer, C.H. Redox homeostasis: Opening up ascorbate transport. Nat. Plants 2015, 1, 114012. [CrossRef]

72. Debolt, S.; Melino, V.; Ford, C.M. Ascorbate as a biosynthetic precursor in plants. Ann. Bot. 2006, 99, 3-8. [CrossRef]

73. Zechmann, B. Diurnal changes of subcellular glutathione content in Arabidopsis thaliana. Biol. Plant. 2017, 61, 791-796. [CrossRef]

74. Hernández, L.E.; Sobrino-Plata, J.; Montero-Palmero, M.B.; Carrasco-Gil, S.; Flores-Cáceres, M.L.; Ortega-Villasante, C.; Escobar, C. Contribution of glutathione to the control of cellular redox homeostasis under toxic metal and metalloid stress. J. Exp. Bot. 2015, 66, 2901-2911. [CrossRef] [PubMed]

75. Lallement, P.A.; Roret, T.; Tsan, P.; Gualberto, J.M.; Girardet, J.M.; Didierjean, C.; Rouhier, N.; Hecker, A. Insights into ascorbate regeneration in plants: Investigating the redox and structural properties of dehydroascorbate reductases from Populus trichocarpa. Biochem. J. 2016, 473, 717-731. [CrossRef] [PubMed]

76. Foyer, C.H.; Noctor, G. Ascorbate and glutathione: The heart of the redox hub. Plant Physiol 2011, 155, 2-18. [CrossRef] [PubMed]

77. Begara-Morales, J.C.; Sánchez-Calvo, B.; Chaki, M.; Valderrama, R.; Mata-Pérez, C.; Corpas, F.J.; Barroso, J.B. Protein $S$-nitrosylation and $S$-glutathionylation as regulators of redox homeostasis during abiotic stress response. In Redox State as a Central Regulator of Plant-Cell Stress Responses; Gupta, D., Palma, J., Corpas, F.J., Eds.; Springer: Cham, Switzerland, 2016; pp. 365-386.

78. Miret, J.A.; Müller, M. AsA/DHA redox pair influencing plant growth and stress tolerance. In Ascorbic Acid in Plant Growth, Development and Stress Tolerance; Hossain, M., Munné-Bosch, S., Burritt, D., Diaz-Vivancos, P., Fujita, M., Lorence, A., Eds.; Springer: Cham, Switzerland, 2017; pp. 297-319.

79. Munné-Bosch, S.; Queval, G.; Foyer, C.H. The impact of global change factors on redox signaling underpinning stress tolerance. Plant Physiol. 2013, 161, 5-19. [CrossRef] [PubMed]

80. Parsons, H.T.; Fry, S.C. Oxidation of dehydroascorbic acid and 2,3-diketogulonate under plant apoplastic conditions. Phytochemistry 2012, 75, 41-49. [CrossRef] [PubMed]

81. Li, R.; Xin, S.; Tao, C.; Jin, X.; Li, H. Cotton ascorbate oxidase promotes cell growth in cultured tobacco bright yellow-2 cells through generation of apoplast oxidation. Int. J. Mol. Sci. 2017, 18, 1346. [CrossRef] [PubMed]

82. Han, Y.; Chaouch, S.; Mhamdi, A.; Queval, G.; Zechmann, B.; Noctor, G. Functional analysis of Arabidopsis mutants points to novel roles for glutathione in coupling $\mathrm{H}_{2} \mathrm{O}_{2}$ to activation of salicylic acid accumulation and signaling. Antioxid. Redox Signal. 2013, 18, 2106-2121. [CrossRef] [PubMed]

83. Czarnocka, W.; Karpiński, S. Friend or foe? Reactive oxygen species production, scavenging and signaling in plant response to environmental stresses. Free Radic. Biol. Medic. 2018, 122, 4-20. [CrossRef] [PubMed]

84. Nafees, M.; Fahad, S.; Shah, F.; Sha, A.M.; Bukhari, M.A.; Maryam; Ahmed, I.; Ahmad, S.; Hussain, S. Reactive Oxygen Species Signaling in Plants. In Reactive Oxygen Species Signaling in Plants; Hasanuzzaman, M., Hakeem, K., Nahar, K., Alharby, H., Eds.; Springer: Cham, Switzerland, 2019; pp. 259-272.

85. Noctor, G.; Reichheld, J.-P.; Foyer, C.H. ROS-related redox regulation and signaling in plants. Sem. Cell Develop. Biol. 2019, 80, 3-12. [CrossRef]

86. Singh, A.; Kumar, A.; Yadav, S.; Singh, I.K. Reactive oxygen species-mediated signaling during abiotic stress. Plant Gene 2019, 18, 100173. [CrossRef]

87. Soares, C.; Carvalho, M.E.A.; Azevedo, R.A.; Fidalgo, F. Plants facing oxidative challenges-A little help from the antioxidant networks. Environ. Exp. Bot. 2019, 161, 4-25. [CrossRef]

88. Hasanuzzaman, M.; Hossain, M.A.; Fujita, M. Exogenous selenium pretreatment protects rapeseed seedlings from cadmium-induced oxidative stress by upregulating antioxidant defense and methylglyoxal detoxification systems. Biol. Trace Elem. Res. 2012, 149, 248-261. [CrossRef] [PubMed]

89. Latowski, D.; Surówka, E.; Strzałka, K. Regulatory role of components of ascorbate-glutathione pathway in plant stress tolerance. In Ascorbate-Glutathione Pathway and Stress Tolerance in Plants; Anjum, N., Chan, M.T., Umar, S., Eds.; Springer: Dordrecht, The Netherlands, 2010; pp. 1-53.

90. Hernández, J.A.; Barba-Espín, G.; Diaz-Vivancos, P. Glutathione-mediated biotic stress tolerance in plants. In Glutathione in Plant Growth, Development, and Stress Tolerance; Hossain, M., Mostofa, M., Diaz-Vivancos, P., Burritt, D., Fujita, M., Tran, L.S., Eds.; Springer: Cham, Switzerland, 2017; pp. 309-319. 
91. Rahman, A.K.; Al Mahmud, J.; Hasanuzzaman, M.; Hossain, M.S.; Fujita, M. Salt stress tolerance in rice: Emerging role of exogenous phytoprotectants. In Advances in International Rice Research; Li, Q., Ed.; InTech: Rijeka, Croatia, 2017; pp. 139-174.

92. Parvin, K.; Hasanuzzaman, M.; Bhuyan, M.H.M.; Mohsin, S.M.; Fujita, M. Quercetin mediated salt tolerance in tomato through the enhancement of plant antioxidant defense and glyoxalase systems. Plants 2019, 8, 247. [CrossRef] [PubMed]

93. Rahman, A.; Nahar, K.; Hasanuzzaman, M.; Fujita, M. Calcium supplementation improves $\mathrm{Na}^{+} / \mathrm{K}^{+}$ratio, antioxidant defense and glyoxalase systems in salt-stressed rice seedlings. Front. Plant Sci. 2016, 7, 609. [CrossRef] [PubMed]

94. Rahman, A.; Nahar, K.; Hasanuzzaman, M.; Fujita, M. Manganese-induced cadmium stress tolerance in rice seedlings: Coordinated action of antioxidant defense, glyoxalase system and nutrient homeostasis. C. R. Biol. 2016, 339, 462-474. [CrossRef] [PubMed]

95. Nahar, K.; Hasanuzzaman, M.; Alam, M.M.; Fujita, M. Roles of exogenous glutathione in antioxidant defense system and methylglyoxal detoxification during salt stress in mung bean. Biol. Plant. 2015, 59, 745-756. [CrossRef]

96. Hossain, M.S.; Alam, M.U.; Rahman, A.; Hasanuzzaman, M.; Nahar, K.; Mahmud, J.A.; Fujita, M. Use of iso-osmotic solution to understand salt stress responses in lentil (Lens culinaris Medik.). S. Afr. J. Bot. 2017, 113, 346-354. [CrossRef]

97. Singh, M.; Singh, V.P.; Prasad, S.M. Nitrogen alleviates salinity toxicity in Solanum lycopersicum seedlings by regulating ROS homeostasis. Plant Physiol. Biochem. 2019, 141, 466-476. [CrossRef] [PubMed]

98. Ahmad, P.; Abd_Allah, E.F.; Alyemeni, M.N.; Wijaya, L.; Alam, P.; Bhardwaj, R.; Siddique, K.H. Exogenous application of calcium to 24-epibrassinosteroid pre-treated tomato seedlings mitigates $\mathrm{NaCl}$ toxicity by modifying ascorbate-glutathione cycle and secondary metabolites. Sci. Rep. 2018, 8, 13515. [CrossRef] [PubMed]

99. Ahanger, M.A.; Alyemeni, M.N.; Wijaya, L.; Alamri, S.A.; Alam, P.; Ashraf, M.; Ahmad, P. Potential of exogenously sourced kinetin in protecting Solanum lycopersicum from $\mathrm{NaCl}$-induced oxidative stress through up-regulation of the antioxidant system, ascorbate-glutathione cycle and glyoxalase system. PLoS ONE 2018, 13, e0202175. [CrossRef]

100. Sehar, Z.; Masood, A.; Khan, N.A. Nitric oxide reverses glucose-mediated photosynthetic repression in wheat (Triticum aestivum L.) under salt stress. Environ. Exp. Bot. 2019, 161, 277-289. [CrossRef]

101. Yan, Y.; Pan, C.; Du, Y.; Li, D.; Liu, W. Exogenous salicylic acid regulates reactive oxygen species metabolism and ascorbate-glutathione cycle in Nitraria tangutorum Bobr. under salinity stress. PMBP 2018, 24, 577-589. [CrossRef] [PubMed]

102. Hossain, M.S.; Hasanuzzaman, M.; Sohag, M.M.H.; Bhuyan, M.H.M.B.; Fujita, M. Acetate-induced modulation of ascorbate: Glutathione cycle and restriction of sodium accumulation in shoot confer salt tolerance in Lens culinaris Medik. PMBP Plants 2019, 25, 443-455. [CrossRef] [PubMed]

103. Talaat, N.B. Effective microorganisms enhance the scavenging capacity of the ascorbate-glutathione cycle in common bean (Phaseolus vulgaris L.) plants grown in salty soils. Plant Physiol. Biochem. 2014, 80, 136-143. [CrossRef] [PubMed]

104. Bhuiyan, T.F.; Ahamed, K.U.; Nahar, K.; Al Mahmud, J.; Bhuyan, M.B.; Anee, T.I.; Fujita, M.; Hasanuzzaman, M. Mitigation of PEG-induced drought stress in rapeseed (Brassica rapa L.) by exogenous application of osmolytes. Biocatal. Agric. Biotechnol. 2019, 20, 101197. [CrossRef]

105. Sun, J.; Gu, J.; Zeng, J.; Han, S.; Song, A.P.; Chen, F.; Fang, W.; Jiang, J.; Chen, S. Changes in leaf morphology, antioxidant activity and photosynthesis capacity in two different drought-tolerant cultivars of chrysanthemum during and after water stress. Sci. Hortic. 2013, 161, 249-258. [CrossRef]

106. Lou, L.; Li, X.; Chen, J.; Li, Y.; Tang, Y.; Lv, J. Photosynthetic and ascorbate-glutathione metabolism in the flag leaves as compared to spikes under drought stress of winter wheat (Triticum aestivum L.). PLoS ONE 2018, 13, e0194625. [CrossRef]

107. Shan, C.; Zhang, S.; Ou, X. The roles of $\mathrm{H}_{2} \mathrm{~S}$ and $\mathrm{H}_{2} \mathrm{O}_{2}$ in regulating AsA-GSH cycle in the leaves of wheat seedlings under drought stress. Protoplasma 2018, 255, 1257-1262. [CrossRef] 
108. Nguyen, K.H.; Mostofa, M.G.; Watanabe, Y.; Tran, C.D.; Rahman, M.M.; Tran, L.S.P. Overexpression of GmNAC085 enhances drought tolerance in Arabidopsis by regulating glutathione biosynthesis, redox balance and glutathione-dependent detoxification of reactive oxygen species and methylglyoxal. Environ. Exp. Bot. 2019, 161, 242-254. [CrossRef]

109. Sreeharsha, R.V.; Mudalkar, S.; Sengupta, D.; Unnikrishnan, D.K.; Reddy, A.R. Mitigation of drought-induced oxidative damage by enhanced carbon assimilation and an efficient antioxidative metabolism under high $\mathrm{CO}_{2}$ environment in pigeonpea (Cajanus cajan L.). Photosynth. Res. 2019, 139, 425-439. [CrossRef] [PubMed]

110. Sarker, U.; Oba, S. Catalase, superoxide dismutase and ascorbate-glutathione cycle enzymes confer drought tolerance of Amaranthus tricolor. Sci. Rep. 2018, 8, 16496. [CrossRef] [PubMed]

111. Nahar, K.; Hasanuzzaman, M.; Alam, M.M.; Fujita, M. Glutathione-induced drought stress tolerance in mung bean: Coordinated roles of the antioxidant defence and methylglyoxal detoxification systems. $A o B$ Plants 2015, 7, plv069. [CrossRef] [PubMed]

112. Lima, C.S.; Ferreira-Silva, S.L.; Carvalho, F.E.L.; Neto, M.C.L.; Aragão, R.M.; Silva, E.N.; Sousa, R.M.J.; Silveira, J.A.G. Antioxidant protection and PSII regulation mitigate photo-oxidative stress induced by drought followed by high light in cashew plants. Environ. Exp. Bot. 2018, 149, 59-69. [CrossRef]

113. Al Mahmud, J.; Biswas, P.K.; Nahar, K.; Fujita, M.; Hasanuzzaman, M. Exogenous application of gibberellic acid mitigates drought-induced damage in spring wheat. Acta Agrobot. 2019, 72, 1776.

114. Hasanuzzaman, M.; Alam, M.; Rahman, A.; Hasanuzzaman, M.; Nahar, K.; Fujita, M. Exogenous proline and glycine betaine mediated upregulation of antioxidant defense and glyoxalase systems provides better protection against salt-induced oxidative stress in two rice (Oryza sativa L.) varieties. BioMed. Res. Int. 2014, 2014, 757219. [CrossRef]

115. Hasanuzzaman, M.; Hossain, M.A.; Fujita, M. Selenium-induced up-regulation of the antioxidant defense and methylglyoxal detoxification system reduces salinity-induced damage in rapeseed seedlings. Biol. Trace Elem. Res. 2011, 143, 1704-1721. [CrossRef]

116. Alam, M.M.; Nahar, K.; Hasanuzzaman, M.; Fujita, M. Alleviation of osmotic stress in Brassica napus, B. campestris, and B. juncea by ascorbic acid application. Biol. Plant. 2014, 58, 697-708. [CrossRef]

117. Alam, M.M.; Hasanuzzaman, M.; Nahar, K.; Fujita, M. Exogenous salicylic acid ameliorates short-term drought stress in mustard (Brassica juncea L.) seedlings by up-regulating the antioxidant defense and glyoxalase system. Aust. J. Crop Sci. 2013, 7, 1053-1063.

118. Jin, X.; Liu, T.; Xu, J.; Gao, Z.; Hu, X. Exogenous GABA enhances muskmelon tolerance to salinity-alkalinity stress by regulating redox balance and chlorophyll biosynthesis. BMC Plant Biol. 2019, 19, 48. [CrossRef]

119. García-Martí, M.; Piñero, M.C.; García-Sanchez, F.; Mestre, T.C.; López-Delacalle, M.; Martínez, V.; Rivero, R.M. Amelioration of the oxidative stress generated by simple or combined abiotic stress through the $\mathrm{K}^{+}$and $\mathrm{Ca}^{2+}$ supplementation in tomato plants. Antioxidants 2019, 8, 81. [CrossRef] [PubMed]

120. Li, J.; Yang, Y.; Sun, K.; Chen, Y.; Chen, X.; Li, X. Exogenous melatonin enhances cold, salt and drought stress tolerance by improving antioxidant defense in tea plant (Camellia sinensis (L.) O. Kuntze). Molecules 2019, 24, 1826. [CrossRef] [PubMed]

121. Ghori, N.-H.; Ghori, T.; Hayat, M.Q.; Imadi, S.R.; Gul, A.; Altay, V.; Ozturk, M. Heavy metal stress and responses in plants. Int. J. Environ. Sci. Technol. 2019, 16, 1807-1828. [CrossRef]

122. Mahmud, J.A.; Hasanuzzaman, M.; Nahar, K.; Rahman, A.; Hossain, M.S.; Fujita, M. Maleic acid assisted improvement of metal chelation and antioxidant metabolism confers chromium tolerance in Brassica juncea $\mathrm{L}$. Ecotoxicol. Environ. Saf. 2017, 144, 216-226. [CrossRef] [PubMed]

123. Hasanuzzaman, M.; Nahar, K.; Gill, S.S.; Alharby, H.F.; Razafindrabe, B.H.N.; Fujita, M. Hydrogen peroxide pretreatment mitigates cadmium-induced oxidative stress in Brassica napus L.: An intrinsic study on antioxidant defense and glyoxalase systems. Front. Plant Sci. 2017, 8, 115. [CrossRef]

124. Bharwana, S.A.; Ali, S.; Farooq, M.A.; Iqbal, N.; Abbas, F.; Ahmad, M.S.A. Alleviation of lead toxicity by silicon is related to elevated photosynthesis, antioxidant enzymes suppressed lead uptake and oxidative stress in cotton. J. Bioremed. Biodeg. 2013, 4, 187.

125. Abd_Allah, E.F.; Hashem, A.; Alam, P.; Ahmad, P. Silicon alleviates nickel-induced oxidative stress by regulating antioxidant defense and glyoxalase systems in mustard plants. J. Plant Growth Regul. 2019, 1-14. [CrossRef] 
126. Rahman, A.; Mostofa, M.G.; Alam, M.M.; Nahar, K.; Hasanuzzaman, M.; Fujita, M. Calcium mitigates arsenic toxicity in rice seedlings by reducing arsenic uptake and modulating the antioxidant defense and glyoxalase systems and stress markers. BioMed. Res. Int. 2015, 2015, 340812. [CrossRef]

127. Hasanuzzaman, M.; Fujita, M. Exogenous sodium nitroprusside alleviates arsenic-induced oxidative stress in wheat (Triticum aestivum L.) seedlings by enhancing antioxidant defense and glyoxalase system. Ecotoxicology 2013, 22, 584-596. [CrossRef]

128. Gill, R.A.; Zang, L.; Ali, B.; Farooq, M.A.; Cui, P.; Yang, S.; Ali, S.; Zhou, W. Chromium-induced physio-chemical and ultrastructural changes in four cultivars of Brassica napus L. Chemosphere 2015, 120, 154-164. [CrossRef]

129. Awasthi, J.P.; Saha, B.; Panigrahi, J.; Yanase, E.; Koyama, H.; Panda, S.K. Redox balance, metabolic fingerprint and physiological characterization in contrasting North East Indian rice for aluminum stress tolerance. Sci. Rep. 2019, 9, 8681. [CrossRef] [PubMed]

130. Nahar, K.; Rahman, M.; Hasanuzzaman, M.; Alam, M.M.; Rahman, A.; Suzuki, T.; Fujita, M. Physiological and biochemical mechanisms of spermine-induced cadmium stress tolerance in mung bean (Vigna radiata L.) seedlings. Environ. Sci. Pollut. Res. Int. 2016, 23, 21206-21218. [CrossRef] [PubMed]

131. Nahar, K.; Rahman, M.; Hasanuzzaman, M.; Alam, M.M.; Rahman, A.; Suzuki, T.; Fujita, M. Polyamine and nitric oxide crosstalk: Antagonistic effects on cadmium toxicity in mungbean plants through upregulating the metal detoxification, antioxidant defense and methylglyoxal detoxification systems. Ecotoxicol. Environ. Saf. 2016, 126, 245-255. [CrossRef] [PubMed]

132. Rahman, A.; Mostofa, M.G.; Nahar, K.; Hasanuzzaman, M.; Fujita, M. Exogenous calcium alleviates cadmium-induced oxidative stress in rice (Oryza sativa L.) seedlings by regulating the antioxidant defense and glyoxalase systems. Braz. J. Bot. 2016, 39, 393-407. [CrossRef]

133. Rahman, A.; Hossain, M.S.; Mahmud, J.A.; Nahar, K.; Hasanuzzaman, M.; Fujita, M. Manganese-induced salt stress tolerance in rice seedlings: Regulation of ion homeostasis, antioxidant defense and glyoxalase systems. PMBP 2016, 22, 291-306. [CrossRef] [PubMed]

134. Wan, Y.; Wang, K.; Liu, Z.; Yu, Y.; Wang, Q.; Li, H. Effect of selenium on the subcellular distribution of cadmium and oxidative stress induced by cadmium in rice (Oryza sativa L.). Environ. Sci. Pollut. Res. 2019, 26, 16220. [CrossRef] [PubMed]

135. Hussain, I.; Siddique, A.; Ashraf, M.A.; Rasheed, R.; Ibrahim, M.; Iqbal, M.; Akbar, S.; Imran, M. Does exogenous application of ascorbic acid modulate growth, photosynthetic pigments and oxidative defense in okra (Abelmoschus esculentus (L.) Moench) under lead stress? Acta Physiol. Plant. 2017, 39, 144. [CrossRef]

136. Mahmud, J.A.; Hasanuzzaman, M.; Nahar, K.; Rahman, A.; Fujita, M. Relative tolerance of different species of Brassica to cadmium toxicity: Coordinated role of antioxidant defense and glyoxalase systems. Plant Omics J. 2017, 10, 107-117. [CrossRef]

137. Mahmud, J.A.; Hasanuzzaman, M.; Nahar, K.; Rahman, A.; Fujita, M. EDTA reduces cadmium toxicity in mustard (Brassica juncea L.) by enhancing metal chelation, antioxidant defense and glyoxalase systems. Acta Agrobot. 2019, 72, 1722. [CrossRef]

138. Mahmud, J.A.; Hasanuzzaman, M.; Nahar, K.; Bhuyan, M.H.M.B.; Fujita, M. Insights into citric acid-induced cadmium tolerance and phytoremediation in Brassica juncea L.: Coordinated functions of metal chelation, antioxidant defense and glyoxalase systems. Ecotoxicol. Environ. Saf. 2018, 147, 990-1001. [CrossRef]

139. Dias, M.C.; Mariz-Ponte, N.; Santos, C. Lead induces oxidative stress in Pisum sativum plants and changes the levels of phytohormones with antioxidant role. Plant Physiol. Biochem. 2019, 137, 121-129. [CrossRef] [PubMed]

140. Kaya, C.; Akram, N.A.; Sürücü, A.; Ashraf, M. Alleviating effect of nitric oxide on oxidative stress and antioxidant defence system in pepper (Capsicum annuum L.) plants exposed to cadmium and lead toxicity applied separately or in combination. Sci. Hortic. 2019, 255, 52-60. [CrossRef]

141. Zhang, K.; Wang, G.; Bao, M.; Wang, L.; Xie, X. Exogenous application of ascorbic acid mitigates cadmium toxicity and uptake in Maize (Zea mays L.). Environ. Sci. Pollut. Res. 2019, 26, 19261-19271. [CrossRef] [PubMed]

142. Rodriguez, V.M.; Soengas, P.; Alonso-Villaverde, V.; Sotelo, T.; Cartea, M.E.; Velasco, M.P. Effect of temperature stress on the early vegetative development of Brassica oleracea L. BMC Plant Biol. 2015, 15, 145. [CrossRef] [PubMed] 
143. Liang, D.; Gao, F.; Ni, Z.; Lin, L.; Deng, Q.; Tang, Y.; Wang, X.; Luo, X.; Xia, H. Melatonin improves heat tolerance in kiwifruit seedlings through promoting antioxidant enzymatic activity and glutathione S-transferase transcription. Molecules 2018, 23, 584. [CrossRef] [PubMed]

144. Gupta, N.K.; Agarwal, S.; Agarwal, V.P.; Nathawat, N.S.; Gupta, S.; Singh, G. Effect of short-term heat stress on growth, physiology and antioxidative defence system in wheat seedlings. Acta Physiol. Plant. 2013, 35, 1837-1842. [CrossRef]

145. Vasseur, F.; Pantin, F.; Vile, D. Changes in light intensity reveal a major role for carbon balance in Arabidopsis responses to high temperature. Plant Cell Environ. 2011, 34, 1563-1576. [CrossRef]

146. Khanna-Chopra, R.; Chauhan, S. Wheat cultivars differing in heat tolerance show a differential response to oxidative stress during monocarpic senescence under high temperature stress. Protoplasma 2015, 25, 1241-1251. [CrossRef]

147. Khanna, P.; Kaur, K.; Gupta, A.K. Salicylic acid induces differential antioxidant response in spring maize under high temperature stress. Indian J. Exp. Biol. 2016, 54, 386-393.

148. Jin, S.H.; Li, X.Q.; Wang, G.G.; Zhu, X.T. Brassinosteroids alleviate high-temperature injury in Ficus concinna seedlings via maintaining higher antioxidant defence and glyoxalase systems. AoB Plants 2015, 7, plv009. [CrossRef]

149. Ahammed, G.J.; Wen, X.; Liu, A.; Chen, S. Endogenous melatonin deficiency aggravates high temperature-induced oxidative stress in Solanum lycopersicum L. Environ. Exp. Bot. 2018, 161, 303-311. [CrossRef]

150. Sang, Q.Q.; Shu, S.; Shana, X.; Guo, S.R.; Sun, J. Effects of exogenous spermidine on antioxidant system of tomato seedlings exposed to high temperature stress. Russ. J. Plant Physiol. 2016, 63, 645-655. [CrossRef]

151. Sgobba, A.; Paradiso, A.; Dipierro, S.; Gara, L.B.; de Pinto, M.C. Changes in antioxidants are critical in determining cell responses to short- and long-term heat stress. Physiol. Plant. 2015, 153, 68-78. [CrossRef] [PubMed]

152. Damanik, R.I.; Maziah, M.; Ismail, M.R.; Ahmad, S.; Zain, A.M. Responses of the antioxidative enzymes in Malaysian rice (Oryza sativa L.) cultivars under submergence condition. Acta Physiol. Plant 2010, 32, $739-747$. [CrossRef]

153. Kim, Y.; Seo, C.W.; Khan, A.L.; Mun, B.G.; Shahzad, R.; Ko, J.W.; Yun, B.W.; Park, S.K.; Lee, I.J. Exo-ethylene application mitigates waterlogging stress in soybean (Glycine max L.). BMC Plant Biol. 2018, 18, 254. [CrossRef] [PubMed]

154. Wang, H.; Chen, Y.; Hu, W.; Snider, J.L.; Zhou, Z. Short-term soil-waterlogging contributes to cotton cross tolerance to chronic elevated temperature by regulating ROS metabolism in the subtending leaf. Plant Physiol. Biochem. 2019, 139, 333-341. [CrossRef]

155. Sairam, R.K.; Kumutha, D.; Ezhilmathi, K.; Chinnusamy, V.; Meena, R.C. Waterlogging induced oxidative stress and antioxidant enzyme activities in pigeon pea. Biol. Plant. 2009, 53, 493-504. [CrossRef]

156. Sairam, R.K.; Dharmar, K.; Lekshmy, S.; Chinnusamy, V. Expression of antioxidant defense genes in mung bean (Vigna radiata L.) roots under water-logging is associated with hypoxia tolerance. Acta Physiol. Plant. 2011, 3, 735-744. [CrossRef]

157. Yiu, J.-C.; Liu, C.-W.; Fang, D.Y.; Lai, Y.-S. Waterlogging tolerance of Welsh onion (Allium fistulosum L.) enhanced by exogenous spermidine and spermine. Plant Physiol. Biochem. 2009, 47, 710-716. [CrossRef]

158. Simova-Stoilova, L.; Demirevska, K.; Kingston-Smith, A.; Feller, U. Involvement of the leaf antioxidant system in the response to soil flooding in two Trifolium genotypes differing in their tolerance to waterlogging. Plant Sci. 2012, 183, 43-49. [CrossRef]

159. Jaiswal, A.; Srivastava, J.P. Changes in reactive oxygen scavenging system and protein profiles in maize roots in response to nitric oxide under waterlogging stress. Indian J. Biochem. Biophys. 2018, 55, 26-33.

160. Woo, S.Y.; Lee, D.K.; Lee, Y.K. Net photosynthetic rate, ascorbate peroxidase and glutathione reductase activities of Erythrina orientalis in polluted and non-polluted areas. Photosynthetica 2007, 45, 293-295. [CrossRef]

161. Seyyednejad, S.M.; Koochak, H.; Vaezi, J. Changes in anti-oxidative enzymes activity, protein content and ascorbic acid level in Prosopis juliflora exposed to industrial air pollution. J. Biol. Today World 2013, 2, 482-492.

162. Lucas, J.A.; Gutierrez-Albanchez, E.; Alfaya, T.; Feo-Brito, F.; Gutiérrez-Mañero, F.J. Oxidative stress in ryegrass growing under different air pollution levels and its likely effects on pollen allergenicity. Plant Physiol. Biochem. 2019, 135, 331-340. [CrossRef] [PubMed] 
163. Wang, J.L.; Zeng, Q.; Zhu, J.G.; Liu, G.; Tang, H.Y. Dissimilarity of ascorbate-glutathione (AsA-GSH) cycle mechanism in two rice (Oryza sativa L.) cultivars under experimental free-air ozone exposure. Agric. Ecosyst. Environ. 2013, 165, 39-49. [CrossRef]

164. Dusart, N.; Gérard, J.; Thiec, D.L.; Collignon, C.; Jolivet, Y.; Vaultier, M.N. Integrated analysis of the detoxification responses of two Euramerican poplar genotypes exposed to ozone and water deficit: Focus on the ascorbate-glutathione cycle. Sci. Total Environ. 2019, 651, 2365-2379. [CrossRef] [PubMed]

165. Muneer, S.; Kim, T.H.; Choi, B.C.; Lee, B.S.; Lee, J.H. Effect of CO, $\mathrm{NO}_{\mathrm{x}}$ and $\mathrm{SO}_{2}$ on ROS production, photosynthesis and ascorbate-glutathione pathway to induce Fragaria $\mathrm{x}$ annasa as a hyperaccumulator. Redox Biol. 2014, 2, 91-98. [CrossRef] [PubMed]

166. Ma, Y.; Wang, B.; Zhang, R.; Gao, Y.; Zhang, X.; Li, Y.; Zuo, Z. Initial simulated acid rain impacts reactive oxygen species metabolism and photosynthetic abilities in Cinnamonum camphora undergoing high temperature. Ind. Crops Prod. 2019, 135, 352-361. [CrossRef]

167. Alamri, S.A.; Siddiqui, M.H.; Al-Khaishany, M.Y.; Khan, M.N.; Ali, H.M.; Alakeel, K.A. Nitric oxide-mediated cross-talk of proline and heat shock proteins induce thermotolerance in Vicia faba L. Environ. Exp. Bot. 2019, 161, 290-302. [CrossRef]

168. Anee, T.I.; Nahar, K.; Rahman, A.; Mahmud, J.A.; Bhuiyan, T.F.; Alam, M.U.; Fujita, M.; Hasanuzzaman, M. Oxidative damage and antioxidant defense in Sesamum indicum after different waterlogging durations. Plants 2019, 8, 196. [CrossRef]

169. Lin, K.H.R.; Weng, C.C.; Lo, H.F.; Chen, J.T. Study of the root antioxidative system of tomatoes and eggplants under waterlogged conditions. Plant Sci. 2004, 167, 355-365. [CrossRef]

170. Bhuyan, M.B.; Hasanuzzaman, M.; Al Mahmud, J.; Hossain, M.S.; Alam, M.U.; Fujita, M. Explicating physiological and biochemical responses of wheat cultivars under acidity stress: Insight into the antioxidant defense and glyoxalase systems. PMBP 2019, 25, 865-879. [CrossRef] [PubMed]

171. Conklin, P.L.; Saracco, S.A.; Norris, S.R.; Last, R.L. Identification of ascorbic acid-deficient Arabidopsis thaliana mutants. Genetics 2000, 154, 847-856. [PubMed]

172. Gao, Q.; Zhang, L. Ultraviolet-B-induced oxidative stress and antioxidant defense system responses in ascorbate-deficient vtc1 mutants of Arabidopsis thaliana. J. Plant Physiol. 2008, 165, 138-148. [CrossRef] [PubMed]

173. Singh, V.P.; Srivastava, P.K.; Prasad, S.M. Differential effect of UV-B radiation on growth, oxidative stress and ascorbate-glutathione cycle in two cyanobacteria under copper toxicity. Plant Physiol. Biochem. 2012, 61, 61-70. [CrossRef] [PubMed]

174. Shiu, C.-T.; Lee, T.-M. Ultraviolet-B-induced oxidative stress and responses of the ascorbate-glutathione cycle in a marine macroalga Ulva fasciata. J. Exp. Bot. 2005, 56, 2851-2865. [CrossRef] [PubMed]

175. Noshi, M.; Hatanaka, R.; Tanabe, N.; Terai, Y.; Maruta, T.; Shigeoka, S. Redox regulation of ascorbate and glutathione by a chloroplastic dehydroascorbate reductase is required for high-light stress tolerance in Arabidopsis. Biosci. Biotechnol. Biochem. 2016, 80, 870-877. [CrossRef]

176. Zheng, L.-D.; Li, M.; Chow, W.S.; Peng, C.-L. Susceptibility of an ascorbate-deficient mutant of Arabidopsis to high-light stress. Photosynthetica 2018, 56, 427-432. [CrossRef]

177. Choudhury, F.K.; Devireddy, A.R.; Azad, R.K.; Shulaev, V.; Mittler, R. Rapid accumulation of glutathione during light stress in Arabidopsis. Plant Cell Physiol. 2018, 59, 1817-1826. [CrossRef]

178. Akram, N.A.; Shafiq, F.; Ashraf, M. Ascorbic acid-a potential oxidant scavenger and its role in plant development and abiotic stress tolerance. Front. Plant Sci. 2017, 8. [CrossRef]

179. Ashraf, M.A.; Riaz, M.; Arif, M.S.; Rasheed, R.; Iqbal, M.; Hussain, I.; Salman, M. The role of non-enzymatic antioxidants in improving abiotic stress tolerance in plants. In Plant Tolerance to Environmental Stress: Role of Phytoprotectants; Hasanuzzaman, M., Fujita, M., Oku, H., Islam, M.T., Eds.; CRC Press: Boca Raton, FL, USA, 2019; pp. 129-143.

180. Naz, H.; Akram, N.A.; Ashraf, M. Impact of ascorbic acid on growth and some physiological attributes of cucumber (Cucumis satious) plants under water-deficit conditions. Pak. J. Bot. 2016, 48, 877-883.

181. Xu, Y.; Huang, B. Exogenous ascorbic acid mediated abiotic stress tolerance in plants. In Ascorbic Acid in Plant Growth, Development and Stress Tolerance; Hossain, M., Munné-Bosch, S., Burritt, D., Diaz-Vivancos, P., Fujita, M., Lorence, A., Eds.; Springer: Cham, Switzerland, 2017; pp. 233-253.

182. Billah, M.; Rohman, M.; Hossain, N.; Uddin, M.S. Exogenous ascorbic acid improved tolerance in maize (Zea mays L.) by increasing antioxidant activity under salinity stress. Afr. J. Agric. Res. 2017, 12, 1437-1446. 
183. Shafiq, S.; Akram, N.A.; Ashraf, M.; Arshad, A. Synergistic effects of drought and ascorbic acid on growth, mineral nutrients and oxidative defense system in canola (Brassica napus L.) plants. Acta Physiol. Plant. 2014, 36, 1539-1553. [CrossRef]

184. Kumar, S.; Kaur, R.; Kaur, N.; Bhandhari, K.; Kaushal, N.; Gupta, K.; Bains, T.; Nayyar, H. Heat-stress induced inhibition in growth and chlorosis in mungbean (Phaseolus aureus Roxb.) is partly mitigated by ascorbic acid application and is related to reduction in oxidative stress. Acta Physiol. Plant. 2011, 33, 2091-2101. [CrossRef]

185. Kobayakawa, H.; Imai, K. Exogenous ascorbic acid scarcely ameliorates inhibition of photosynthesis in rice leaves by $\mathrm{O}_{3}$. Plant Prod. Sci. 2017, 20, 83-89. [CrossRef]

186. Wang, J.; Wu, B.; Yin, H.; Fan, Z.; Li, X.; Ni, S.; He, L.; Li, J. Overexpression of CaAPX induces orchestrated reactive oxygen scavenging and enhances cold and heat tolerances in tobacco. BioMed. Res. Int. 2017, 2017, 4049534. [CrossRef] [PubMed]

187. Saeidi-Sar, S.; Abbaspour, H.; Afshari, H.; Yaghoobi, S.R. Effects of ascorbic acid and gibberellin A3 on alleviation of salt stress in common bean (Phaseolus vulgaris L.) seedlings. Acta Physiol. Plant. 2013, 35, 667-677. [CrossRef]

188. Rehman, R.U.; Zia, M.; Abbasi, B.H.; Lu, G.; Chaudhary, M.F. Ascorbic acid and salicylic acid mitigate $\mathrm{NaCl}$ stress in Caralluma tuberculata Calli. Appl. Biochem. Biotechnol. 2014, 173, 968-979. [CrossRef]

189. Wang, R.; Liu, S.; Zhou, F.; Ding, C.; Hua, C. Exogenous ascorbic acid and glutathione alleviate oxidative stress induced by salt stress in the chloroplasts of Oryza sativa L. Z. Naturforsch. C 2014, 69, 226-236. [CrossRef]

190. Rady, M.M.; Hemida, K.A. Sequenced application of ascorbate-proline-glutathione improves salt tolerance in maize seedlings. Ecotoxicol. Environ. Saf. 2016, 133, 252-259. [CrossRef]

191. Terzi, R.; Kalaycioglu, E.; Demiralay, M.; Saglam, A.; Kadioglu, A. Exogenous ascorbic acid mitigates accumulation of abscisic acid, proline and polyamine under osmotic stress in maize leaves. Acta Physiol. Plant. 2015, 37, 43. [CrossRef]

192. Xu, Y.; Xu, Q.; Huang, B. Ascorbic acid mitigation of water stress-inhibition of root growth in association with oxidative defense in tall fescue (Festuca arundinacea Schreb. ) Front. Plant Sci. 2015, 6, 807. [CrossRef] [PubMed]

193. Zhang, C.; Liu, J.; Zhang, Y.; Cai, X.; Gong, P.; Zhang, J.; Wang, T.; Li, H.; Ye, Z. Overexpression of SlGMEs leads to ascorbate accumulation with enhanced oxidative stress, cold, and salt tolerance in tomato. Plant Cell Rep. 2011, 30, 389-398. [CrossRef] [PubMed]

194. Wang, X.; Wu, L.; Xie, J.; Li, T.; Cai, J.; Zhou, Q.; Dai, T.; Jiang, D. Herbicide isoproturon aggravates the damage of low temperature stress and exogenous ascorbic acid alleviates the combined stress in wheat seedlings. Plant Growth Regul. 2018, 84, 293-301. [CrossRef]

195. Chao, Y.Y.; Hong, C.Y.; Kao, C.H. The decline in ascorbic acid content is associated with cadmium toxicity of rice seedlings. Plant Physiol. Bioch. 2010, 48, 374-381. [CrossRef] [PubMed]

196. Alamri, S.A.; Siddiqui, M.H.; Al-Khaishany, M.Y.; Nasir Khan, M.; Ali, H.M.; Alaraidh, I.A.; Alsahli, A.A.; Al-Rabiah, H.; Mateen, M. Ascorbic acid improves the tolerance of wheat plants to lead toxicity. J. Plant Interact. 2018, 13, 409-419. [CrossRef]

197. Ding, X.; Jiang, Y.; He, L.; Zhou, Q.; Yu, J.; Hui, D.; Huang, D. Exogenous glutathione improves high root-zone temperature tolerance by modulating photosynthesis, antioxidant and osmolytes systems in cucumber seedlings. Sci. Rep. 2016, 6, 35424. [CrossRef] [PubMed]

198. Cao, F.; Liu, L.; Ibrahim, W.; Cai, Y.; Wu, F. Alleviating effects of exogenous glutathione, glycinebetaine, brassinosteroids and salicylic acid on cadmium toxicity in rice seedlings (Oryza sativa). Agrotechnology 2013, 2, 107. [CrossRef]

199. Yuan, H.; Zhang, Y.; Huang, S.; Yang, Y.; Gu, C. Effects of exogenous glutathione and cysteine on growth, lead accumulation, and tolerance of Iris lactea var. chinensis. Environ. Sci. Pollut. Res. 2015, 22, 2808-2816. [CrossRef]

200. Kim, Y.-O.; Bae, H.-J.; Cho, E.; Kang, H. Exogenous Glutathione Enhances Mercury Tolerance by Inhibiting Mercury Entry into Plant Cells. Front. Plant Sci. 2017, 8, 683. [CrossRef]

201. Zhou, Y.; Wen, Z.; Zhang, J.; Chen, X.; Cui, J.; Xu, W.; Liu, H. Exogenous glutathione alleviates salt-induced oxidative stress in tomato seedlings by regulating glutathione metabolism, redox status, and the antioxidant system. Sci. Hortic. 2017, 220, 90-101. [CrossRef] 
202. Akram, S.; Siddiqui, M.N.; Hussain, B.N.; Al Bari, M.A.; Mostofa, M.G.; Hossain, M.A.; Tran, L.S.P. Exogenous glutathione modulates salinity tolerance of soybean [Glycine max (L.) Merrill] at reproductive stage. J. Plant Growth Regul. 2017, 36, 877-888. [CrossRef]

203. Zhou, Y.; Diao, M.; Cui, J.; Chen, X.; Wen, Z.; Zhang, J.; Liu, H. Exogenous GSH protects tomatoes against salt stress by modulating photosystem II efficiency, absorbed light allocation and $\mathrm{H}_{2} \mathrm{O}_{2}$-scavenging system in chloroplasts. J. Integr. Agric. 2018, 17, 2257-2272. [CrossRef]

204. Romero-Puertas, M.C.; Sandalio, L.M. Nitric oxide level is self-regulating and also regulates its ROS partners. Front. Plant Sci. 2016, 7, 316. [CrossRef] [PubMed]

205. Yang, H.; Mu, J.; Chen, L.; Feng, J.; Hu, J.; Li, L.; Zhou, J.M.; Zuo, J. S-Nitrosylation positively regulates ascorbate peroxidase activity during plant stress responses. Plant Physiol. 2015, 167, 1604-1615. [CrossRef] [PubMed]

206. Begara-Morales, J.C.; Sánchez-Calvo, B.; Chaki, M.; Mata-Pérez, C.; Valderrama, R.; Padilla, M.N.; López-Jaramillo, J.; Luque, F.; Corpas, F.J.; Barroso, J.B. Differential molecular response of monodehydroascorbate reductase and glutathione reductase by nitration and S-nitrosylation. J. Exp. Bot. 2015, 66, 5983-5996. [CrossRef]

207. Tanou, G.; Filippou, P.; Belghazi, M.; Job, D.; Diamantidis, G.; Fotopoulos, V.; Molassiotis, A. Oxidative and nitrosative-based signaling and associated post-translational modifications orchestrate the acclimation of citrus plants to salinity stress. Plant J. 2012, 72, 585-599. [CrossRef]

208. Groß, F.; Durner, J.; Gaupels, F. Nitric oxide, antioxidants and prooxidants in plant defence responses. Front. Plant Sci. 2013, 4, 419. [CrossRef]

209. Demidchik, V.; Shabala, S. Mechanisms of cytosolic calcium elevation in plants: The role of ion channels,

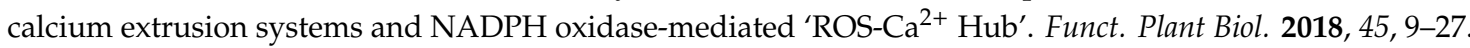
[CrossRef]

210. Smirnoff, N.; Wheeler, G.L. Ascorbic acid in plants: Biosynthesis and function. Crit. Rev. Plant Sci. 2000, 19, 267-290. [CrossRef]

211. Gallie, D.R. L-ascorbic acid: A multifunctional molecule supporting plant growth and development. Scientifica 2013, 2013, 795964. [CrossRef] [PubMed]

212. Makavitskaya, M.; Svistunenko, D.; Navaselsky, I.; Hryvusevich, P.; Mackievic, V.; Rabadanova, C.; Tyutereva, E.; Samokhina, V.; Straltsova, D.; Sokolik, A.; et al. Novel roles of ascorbate in plants: Induction of cytosolic $\mathrm{Ca}^{2+}$ signals and efflux from cells via anion channels. J. Exp. Bot. 2018, 69, 3477-3489. [CrossRef] [PubMed]

213. Kuźniak, E.; Kaźmierczak, A.; Wielanek, M.; Głowacki, R.; Kornas, A. Involvement of salicylic acid, glutathione and protein S-thiolation in plant cell death-mediated defence response of Mesembryanthemum crystallinum against Botrytis cinerea. Plant Physiol. Biochem. 2013, 63, 30-38. [CrossRef] [PubMed]

214. Bedhomme, M.; Adamo, M.; Marchand, C.H.; Couturier, J.; Rouhier, N.; Lemaire, S.D.; Zaffagnini, M.; Trost, P. Glutathionylation of cytosolic glyceraldehyde-3-phosphate dehydrogenase from the model plant Arabidopsis thaliana is reversed by both glutaredoxins and thioredoxins in vitro. Biochem. J. 2012, 445, 337-347. [CrossRef] [PubMed]

215. Akter, N.; Okuma, E.; Sobahan, M.A.; Uraji, M.; Munemasa, S.; Nakamura, Y.; Mori, I.C.; Murata, Y. Negative regulation of methyl jasmonate-induced stomatal closure by glutathione in Arabidopsis. J. Plant Growth Regul. 2013, 32, 208-215. [CrossRef]

216. Li, F.; Wang, J.; Ma, C.; Zhao, Y.; Wang, Y.; Hasi, A.; Qi, Z. Glutamate receptor-like channel 3.3 is involved in mediating glutathione-triggered cytosolic calcium transients, transcriptional changes, and innate immunity responses in Arabidopsis. Plant Physiol. 2013, 162, 1497-1509. [CrossRef] [PubMed]

217. Liebthal, M.; Maynard, D.; Dietz, K.J. Peroxiredoxins and redox signaling in plants. Antioxid. Redox Signal. 2018, 28, 609-624. [CrossRef]

218. Mailloux, R.J.; Treberg, J.R. Protein S-glutathionlyation links energy metabolism to redox signaling in mitochondria. Redox Biol. 2016, 8, 110-118. [CrossRef]

219. Czerniawski, P.; Bednarek, P. Glutathione S-Transferases in the Biosynthesis of Sulfur-Containing Secondary Metabolites in Brassicaceae Plants. Front. Plant Sci. 2018, 9, 1639. [CrossRef]

220. Benjeddou, H.; Ahmed, C.B.; Rouina, B.B. Influence of antioxidative enzymes, phytohormones and pigments in alternate bearing of three olive cultivars. Sci. Hortic. 2019, 253, 17-23. [CrossRef] 
221. Brunetti, C.; Fini, A.; Sebastiani, F.; Gori, A.; Tattini, M. Modulation of phytohormone signaling: A primary function of flavonoids in plant-environment interactions. Front. Plant Sci. 2018, 9, 1042. [CrossRef] [PubMed]

222. Yu, Y.; Wang, J.; Li, S.; Kakan, X.; Zhou, Y.; Miao, Y.; Wang, F.; Qin, H.; Huang, R. Ascorbic acid integrates the antagonistic modulation of ethylene and abscisic acid in the accumulation of reactive oxygen species. Plant Physiol. 2019, 179, 1861-1875. [CrossRef] [PubMed]

223. Lu, Y.; Chang, X.; Guo, X. Dynamic changes of ascorbic acid, phenolics biosynthesis and antioxidant activities in mung beans (Vigna radiata) until maturation. Plants 2019, 8, 75. [CrossRef] [PubMed]

224. Huang, D.; Huo, J.; Zhang, J.; Wang, C.; Wang, B.; Fang, H.; Liao, W. Protein S-nitrosylation in programmed cell death in plants. Cell. Mol. Life Sci. 2019, 76, 1877-1887. [CrossRef] [PubMed]

225. Datta, R.; Kumar, D.; Sultana, A.; Hazra, S.; Bhattacharyya, D.; Chattopadhyay, S. Glutathione regulates 1-aminocyclopropane-1-carboxylate synthase transcription via WRKY33 and 1-aminocyclopropane-1-carboxylate oxidase by modulating messenger RNA stability to induce ethylene synthesis during stress. Plant Physiol. 2015, 169, 2963-2981. [PubMed]

226. Singh, A.P.; Dixit, G.; Mishra, S.; Dwivedi, S.; Tiwari, M.; Mallick, S.; Pandey, V.; Trivedi, P.K.; Chakrabarty, D.; Tripathi, R.D. Salicylic acid modulates arsenic toxicity by reducing its root to shoot translocation in rice (Oryza sativa L.). Front. Plant Sci. 2015, 6, 340. [CrossRef] [PubMed]

227. Cheng, M.C.; Ko, K.; Chang, W.L.; Kuo, W.C.; Chen, G.H.; Lin, T.P. Increased glutathione contributes to stress tolerance and global translational changes in Arabidopsis. Plant J. 2015, 83, 926-939. [CrossRef] [PubMed]

228. Labrou, N.E.; Papageorgiou, A.C.; Pavli, O.; Flemetakis, E. Plant GSTome: Structure and functional role in xenome network and plant stress response. Curr. Opin. Biotechnol. 2015, 32, 186-194. [CrossRef]

229. Sevilla, F.; Camejo, D.; Ortiz-Espín, A.; Calderón, A.; Lázaro, J.J.; Jiménez, A. The thioredoxin/peroxiredoxin/sulfiredoxin system: Current overview on its redox function in plants and regulation by reactive oxygen and nitrogen species. J. Exp. Bot. 2015, 66, 2945-2955. [CrossRef]

230. Cao, S.; Du, X.-H.; Li, L.-H.; Liu, Y.-D.; Zhang, L.; Pan, X.; Li, Y.; Li, H. Overexpression of Populus tomentosa cytosolic ascorbate peroxidase enhances abiotic stress tolerance in tobacco plants. Russ. J. Plant Physiol. 2017, 64, 224-234. [CrossRef]

231. Chin, D.-C.; Kumar, R.S.; Suen, C.-S.; Chien, C.-Y.; Hwang, M.-J.; Hsu, C.-H.; Xuhan, X.; Lai, Z.X.; Yeh, K.W. Plant cytosolic ascorbate peroxidase with dual catalytic activity modulates abiotic stress tolerances. iScience 2019, 16, 31-49. [CrossRef] [PubMed]

232. Eltelib, H.A.; Fujikawa, Y.; Esaka, M. Overexpression of the acerola (Malpighia glabra) monodehydroascorbate reductase gene in transgenic tobacco plants results in increased ascorbate levels and enhanced tolerance to salt stress. S. Afr. J. Bot. 2012, 78, 295-301. [CrossRef]

233. Shin, S.-Y.; Kim, M.-H.; Kim, Y.-H.; Park, H.M.; Yoon, H.-S. Co-Expression of monodehydroascorbate reductase and dehydroascorbate reductase from Brassica rapa effectively confers tolerance to freezing-induced oxidative stress. Mol. Cells 2013, 36, 304-315. [CrossRef] [PubMed]

234. Yin, L.; Mano, J.; Tanaka, K.; Wang, S.; Zhang, M.; Deng, X.; Zhang, S. High level of reduced glutathione contributes to detoxification of lipid peroxide-derived reactive carbonyl species in transgenic Arabidopsis overexpressing glutathione reductase under aluminum stress. Physiol. Plant. 2017, 161, 211-223. [CrossRef] [PubMed]

235. Mao, C.; Ding, J.; Zhang, B.; Xi, D.; Ming, F. OsNAC2 positively affects salt-induced cell death and binds to the OsAP37 and OsCOX11 promoters. Plant J. 2018, 94, 454-468. [CrossRef]

236. Borgohain, P.; Saha, B.; Agrahari, R.; Chowardhara, B.; Sahoo, S.; van der Vyver, C.; Panda, S.K. SINAC2 overexpression in Arabidopsis results in enhanced abiotic stress tolerance with alteration in glutathione metabolism. Protoplasma 2019, 256, 1065. [CrossRef]

237. Zhang, Q.; Ma, C.; Xue, X.; Xu, M.; Li, J.; Wu, J.-X. Overexpression of a cytosolic sscorbate peroxidase gene, OsAPX2, increases salt tolerance in transgenic Alfalfa. J. Integr. Agric. 2014, 13, 2500-2507. [CrossRef]

238. Wang, Z.; Li, Q.; Wu, W.; Guo, J.; Yang, Y. Cadmium stress tolerance in wheat seedlings induced by ascorbic acid was mediated by NO signaling pathways. Ecotoxicol. Environ. Saf. 2017, 135, 75-81. [CrossRef]

239. Liu, F.; Huang, N.; Wang, L.; Ling, H.; Sun, T.; Ahmad, W.; Muhammad, K.; Guo, J.; Xu, L.; Gao, S.; et al. A novel L-ascorbate peroxidase 6 gene, ScAPX6, plays an important role in the regulation of response to biotic and abiotic stresses in sugarcane. Front. Plant Sci. 2018, 8, 2262. [CrossRef]

240. Chin, D.C.; Hsieh, C.C.; Lin, H.Y.; Yeh, K.W. A low glutathione redox state couples with a decreased ascorbate redox ratio to accelerate flowering in Oncidium orchid. Plant Cell Physiol. 2016, 57, 423-436. [CrossRef] 
241. Kavitha, K.; George, S.; Venkataraman, G.; Parida, A. A salt-inducible chloroplastic monodehydroascorbate reductase from halophyte Avicennia marina confers salt stress tolerance on transgenic plants. Biochimie 2010, 92, 1321-1329. [CrossRef] [PubMed]

242. Kwon, S.Y.; Choi, S.M.; Ahn, Y.O.; Lee, H.S.; Lee, H.B.; Park, Y.M.; Kwak, S.S. Enhanced stress-tolerance of transgenic plants expressing a human dehydroascorbate reductase gene. J. Plant Physiol. 2003, 160, 347-353. [CrossRef] [PubMed]

243. Ushimaru, T.; Nakagawa, T.; Fujioka, Y.; Daicho, K.; Naito, M.; Yamauchi, Y.; Nonaka, H.; Amako, K.; Yamawaki, K.; Murata, N. Transgenic Arabidopsis plants expressing the rice dehydroascorbate reductase gene are resistant to salt stress. J. Plant Physiol. 2006, 163, 1179-1184. [CrossRef] [PubMed]

244. Lee, Y.P.; Kim, S.H.; Bang, J.W.; Lee, H.S.; Kwak, S.S.; Kwon, S.Y. Enhanced tolerance to oxidative stress in transgenic tobacco plants expressing three antioxidant enzymes in chloroplasts. Plant Cell Rep. 2007, 26, 591-598. [CrossRef]

245. Wang, H.S.; Yu, C.; Zhu, Z.J.; Yu, X.C. Overexpression in tobacco of a tomato GMPase gene improves tolerance to both low and high temperature stress by enhancing antioxidation capacity. Plant Cell Rep. 2011, 30, 1029-1040. [CrossRef] [PubMed]

246. Le Martret, B.; Poage, M.; Shiel, K.; Nugent, G.D.; Dix, P.J. Tobacco chloroplast transformants expressing genes encoding dehydroascorbate reductase, glutathione reductase, and glutathione-S-transferase, exhibit altered anti-oxidant metabolism and improved abiotic stress tolerance. Plant Biotechnol. J. 2011, 9, 661-673. [CrossRef] [PubMed]

(C) 2019 by the authors. Licensee MDPI, Basel, Switzerland. This article is an open access article distributed under the terms and conditions of the Creative Commons Attribution (CC BY) license (http://creativecommons.org/licenses/by/4.0/). 